\title{
Shareholder Value and Workforce Downsizing, 1981-2006
}

\section{Citation}

Jung, Jin Wook. 2012. Shareholder Value and Workforce Downsizing, 1981-2006. Doctoral dissertation, Harvard University.

\section{Permanent link}

http://nrs.harvard.edu/urn-3:HUL.InstRepos:9909630

\section{Terms of Use}

This article was downloaded from Harvard University's DASH repository, and is made available under the terms and conditions applicable to Other Posted Material, as set forth at http:// nrs.harvard.edu/urn-3:HUL.InstRepos:dash.current.terms-of-use\#LAA

\section{Share Your Story}

The Harvard community has made this article openly available.

Please share how this access benefits you. Submit a story.

\section{Accessibility}


(C)2012 - Ji Wook Jung

All rights reserved. 
Shareholder Value and Workforce Downsizing, 1981-2006

\begin{abstract}
Even before the current economic meltdown, waves of downsizing, starting in the late 1970s, had swept corporate America, eroding workers' expectations of economic security. But not only did downsizing become more prevalent during this period; its basic nature changed. Previously, firms had cut jobs temporarily, to adjust the size of their workforce during a downturn. Since the late 70s, firms have increasingly cut jobs in both good and bad times, in order to boost stock price.
\end{abstract}

My dissertation examines the inter-group power dynamics underlying the transformation of workforce downsizing as a shareholder-value strategy. Examining both downsizing announcements from more than 700 leading U.S. corporations between 1981 and 2006, and actual implementation of the announced downsizing plans, I find at work in the process a shift in ideology, from an emphasis on corporate growth and conglomeration to an emphasis on profitability and shareholder value, an ideology that both reflects and intensifies the growing influence of shareholders over firms and the declining role of labor.

My first empirical chapter examines the role of institutional investors and shareholdervalue-oriented managers in the transformation. The second empirical chapter examines the potential resistance from labor unions and shows how the anti-union stance of the public policy regime in the 1980s weakened unions' power to resist. The last empirical chapter examines the role of investors, unions, and executives in the implementation of announced downsizing plans and demonstrates the contested nature of the implementation process. 
Together, these three chapters illustrate the class politics simmering under the surface of the acceptance of downsizing for shareholder-value maximization, and emphasize the role of agency and power, as constructed by particular institutional logics, not only in promoting but also resisting the process of institutional change. 


\section{TABLE OF CONTENTS}

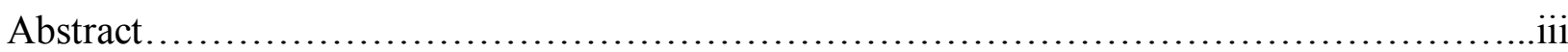

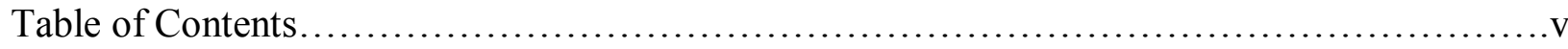

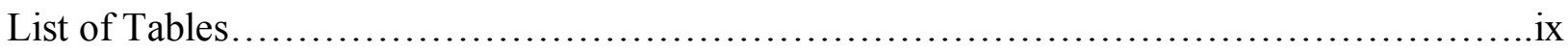

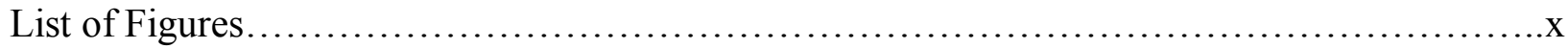

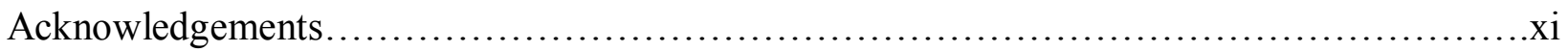

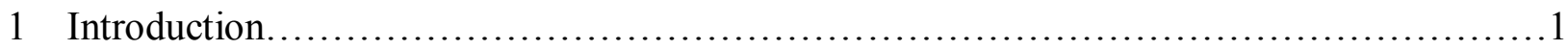

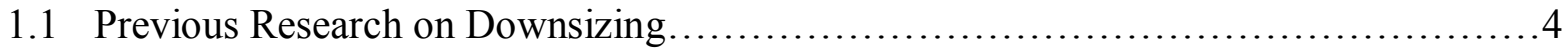

1.1.1 Economic Research on Downsizing .....................................5

1.1.2 Sociological Research on Downsizing: A New Paradigm of the Firm.............9

1.2 Socio-Political Account of the Transformation of Downsizing ........................10

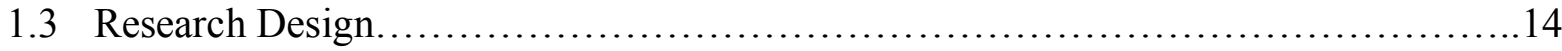

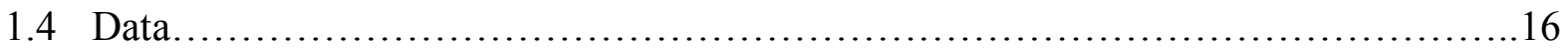

1.5 Structure of the Dissertation.................................................... 17

2 The Transformation of Workforce Downsizing as a Shareholder-Value

Strategy............18Workforce Downsizing as a Shareholder-Value

Strategy................................21

2.2 Two Explanations: Resource Dependence and Decision Context.....................23

2.2.1 Resource Dependence and External Pressure from Institutional Investors.........23

2.2.2 New Decision Context and Reorientation of Managerial Behavior...............27

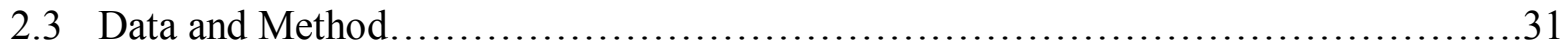

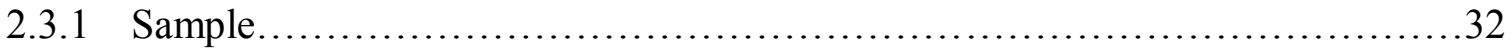


2.3.2 Dependent Variable: Downsizing Announcements.............................33

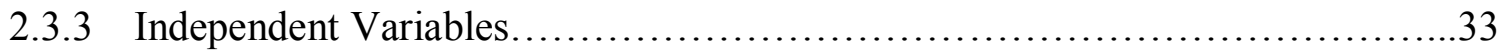

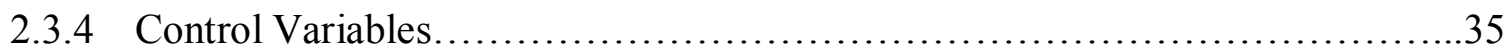

2.3.5 Missing Values and Multiple Imputation....................................37

2.3.6 Modeling Procedure.......................................................... 38

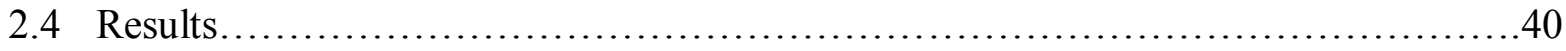

2.4.1 Resource-Dependence Predictions..........................................41

2.4.2 Decision-Context Predictions............................................46

2.4.3 Control Variables..............................................................

2.4.4 Robustness Checks................................................... 47

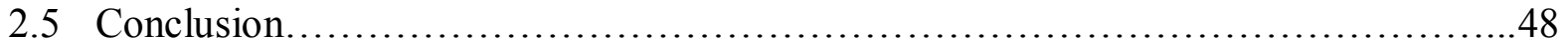

3 Labor Resistance, Public Policy, and Changing Layoff Policies.......................... 53

3.1 Public Policy and Institutional Change.............................................5

3.2 The Transition from Temporary to Permanent Layoff................................58

3.2.1 Industrial Unionism and Temporary Layoff.................................59

3.2.2 Shareholder Value and Permanent Layoff...................................61

3.3 The Role of Public Policy in the Shift of Layoff Policies...............................62

3.3.1 Resistance from Labor Unions...........................................63

3.3.2 Cognitive-Cultural Legitimacy of Temporary versus Permanent Layoff...........64

3.3.3 The Role of Public Policy ...................................................66

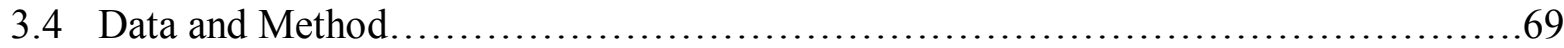

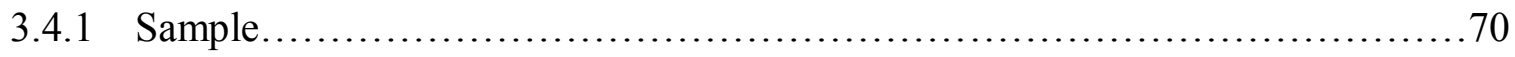

3.4.2 Dependent Variable: Layoff Announcements................................70 
3.4.3 Independent Variables.....................................................

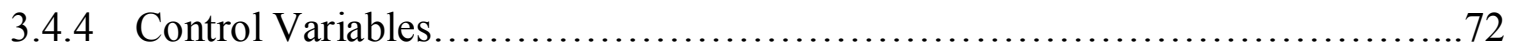

3.4.5 Missing Values and Multiple Imputation....................................75

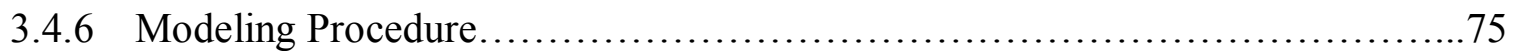

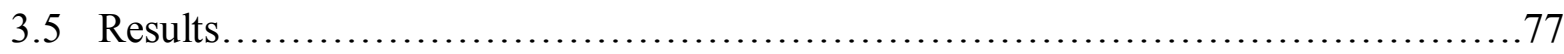

3.5.1 Union Resistance and Public Policy...........................................78

3.5.2 Density-Dependence Legitimation and Public Policy...........................80

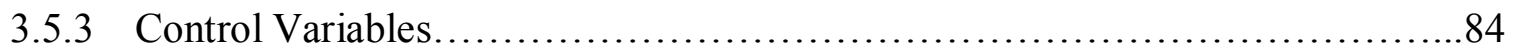

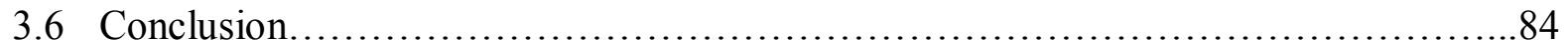

4 Multiple Institutional Demands and Implementation of Workforce Downsizing by Firms...89

4.1 Conflicting Institutional Demands and Policy Implementation......................92

4.2 Workforce Downsizing and Its implementation.................................... 96

4.3 Inter-Group Struggle over the Implementation of Downsizing .......................98

4.3.1 Pressure from Institutional Investors........................................99

4.3.2 Resistance from Labor Unions........................................... 100

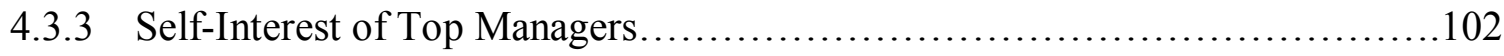

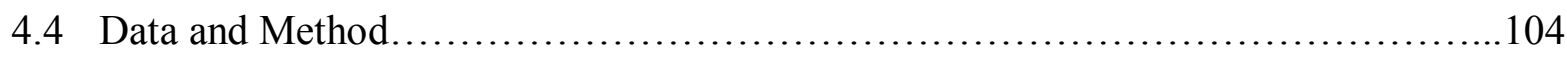

$4.4 .1 \quad$ Sample................................................................... 104

4.4.2 Dependent Variables...................................................... 105

4.4.3 Independent Variables.................................................. 105

4.4.4 Control Variables...................................................... 107

4.4.5 Missing Values and Multiple Imputation...................................110

4.4.6 Statistical Method..................................................... 110 
4.5 Results................................................................... 111

4.5.1 Main Effects of Downsizing Announcements..............................111

4.5.2 Interaction Effects.............................................. 114

4.5.3 Control Variables....................................................117

4.6 Conclusion............................................................. 118

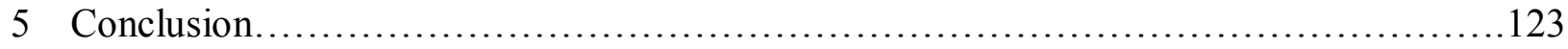

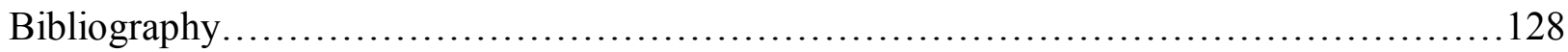




\section{LIST OF TABLES}

Table 2.1: Data Sources and Descriptive Statistics.................................... 36

Table 2.2: Continuous-Time Event History Analysis of Downsizing Announcements..........42

Table 3.1: Variable Definitions, Data Sources, and Univariate Statistics.....................74

Table 3.2: Event-History Analysis of Temporary versus Permanent Layoff Announcements....81

Table 4.1: Data Sources and Descriptive Statistics...................................... 108

Table 4.2: Fixed-Effects Estimates of the Percentage Change in the Total Number of

Employees..........................................................112

Table 4.3: Fixed-Effects Estimates of the Log Odds of Managerial Employees.................113 


\section{LIST OF FIGURES}

Figure 2.1: Downsizing Announcements..........................................41

Figure 2.2: Changes in Institutional Ownership before Downsizing Announcements...........45

Figure 3.1: Temporary and Permanent Layoff Announcements (All Sampled Firms)............79

Figure 3.2: Temporary and Permanent Layoff Announcements (Firms in the Transportation

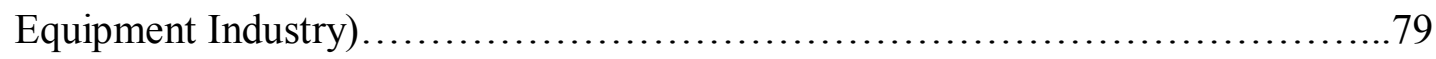

Figure 4.1: Interaction Effects with Institutional Ownership...........................116

Figure 4.2: Interaction Effects with Union Density.................................116

Figure 4.3: Interaction Effects with CEO Stock Options............................ 117 


\section{ACKNOWLEDGEMENTS}

This dissertation would not have been possible without a great deal of professional and personal support from my dissertation committee. My committee members, Frank Dobbin (Chair), Christopher Marquis, and Peter V. Marsden provided excellent guidance and invaluable advice through the years of my graduate student career. Frank Dobbin was an advisor whom I appreciated more and more as my time in graduate school passed. He was the reason I came to Harvard, and, after taking his seminar course on organizational sociology, I decided, without hesitation, to have him as my adviser. Ever since then, he helped me grow as a person and a researcher with his attention to the details as well as the big picture of my life and research. Throughout my graduate studies in both U.S. and South Korea, I met many great scholars, whose footsteps would continue to guide my future academic career. Frank is the greatest of them.

Christopher Marquis came to Harvard Business School when I was writing my qualifying paper, and willingly accepted my offer to be on my committed. Since then, he was always the right person to ask for advice about personal and professional development, and was very generous about his time whenever I needed his input. He was a great source of theoretical inspiration for my research. My research always benefited tremendously from his thoughtful and incisive comments and suggestions. Peter V. Marsden was another great source of inspiration. I learned greatly from his approach to research and teaching. He truly embodied a standard of academic rigor that is exemplary. Without his advice and guidance, I would not have achieved the level of analytical rigor for my dissertation research. I also learned a lot from my teaching assistantship for his courses. His dedication to teaching was almost legendary, something I would not be able to even imitate. 
I benefited from generous financial support from Harvard during my graduate studies. Eliot Dissertation Completion Fellowship provided funding that allowed me to primarily focus on research during the last year. Doctoral Dissertation Improvement Grant from National Science Foundation also supported this dissertation research at the early stage.

My friendship with fellow graduate students at Harvard was a critical source of support and inspiration, which helped me get through the years. It was very lucky of me to have the FMF meetings during the later part of my study here. The meeting started as a small research meeting with Frank and his graduate students, Soohan Kim, Dian Yang, and me. We continued the tradition while Frank was away in France during his sabbatical leave. I thank FMF members, Evgeny Firsov, Carl Gershenson, Gru Han, Soohan Kim, Dong Ju Lee, Eunmi Mun, Kim Pernell, Dan Schrage, Sameer Srivastava, Andras Tilcsik, and Shawna Bowden Vican, for their constructive feedback and warm support. The friendship with Jeff Denis, Dong Kyun Im, Chaeyoon Lim, Kevin Lewis, Eun Sil Oh, Sanjay Pinto, Tracey Shollenberger, Vaughn Tan, Jessica Welburn, and Min Zhou was a great source of support, which made my life at Harvard a much more memorable one.

I also have received enormous professional and personal support from outside Harvard. I am indebted to the faculty members of the Sociology Department at Seoul National University. In particular, Jaeyeol Yee introduced me to sociological research and encouraged me to pursue graduate studies. I benefited from my interaction with several Korean visiting scholars to Harvard, including Dukjin Chang, Joon Han, Chanwoong Park, Taekyun Park, Jaeyoun Won. Taekjin Shin was one of my best friends from my undergraduate years and continued to be a great source of professional as well as personal support since both of us came here to pursue graduate studies. Guilhem Bascle now at Erasmus University was always a great friend and 
colleague ever since we met in 2006 when he was a visiting student to Harvard. Finally, I deeply thank Gordon Harvey who walked me through academeic writing and reason with great patience. Without his support, the writing of this dissertation would have simply been an impossible task for me.

Finally, I want to thank my family and friends in Korea from their everlasting love and support. Thanks especially to my parents and my brother for placing their confidence in me. My oldest and dearest friends, Hyungman, Insoo, Jungjoon, Junkyu, always filled me with comfort. My wife colleague, Eunmi, has been with me through it all, and she is truly my better self. I would not have made it through graduate school if I did not have her. 


\section{INTRODUCTION}

In February, 1993, IBM, the world's largest computer maker, announced that it would order the first layoffs in its 80 -year history. This announcement came after months of hinting. When IBM said in December of the previous year that it would cut 25,000 jobs, it warned that some of these cuts might be made through layoffs. Although the company was a pioneer in personal computers, it had suffered from a steady decline in profitability and slow growth in past years. Its decline was due in large part to a strategic mistake it made at the beginning of the 1980s; it over-hired and over-built in expectation that business would be better. Instead, the company was faced with a prolonged industry-wide slackening of demand for computers and tougher international as well as domestic competition. Therefore, the company needed to adjust its total work force and reduce costs, to return to profitability and maintain its competitive edge.

Nevertheless, IBM's decision to make layoffs marked a drastic departure from its acclaimed tradition of full employment. Throughout its history, the company had prided itself on caring for its employees. Even when the company needed to adjust its work force in a period of weak demand, it relied on normal attrition, limited hiring, and early retirement incentives, rather than massive layoffs. During the downturn in the computer industry in 1986, it offered its senior employees special incentives for retiring early, and more than 10,000 of its U.S employees accepted them (Coy 1986). In the same year, when the company closed a parts distribution center in Greencastle, Indiana (the biggest closing of a facility in its history), it offered jobs elsewhere within the company to all of the 985 displaced workers, in keeping with its full-employment tradition (Huddleston 1986). Even during the severe recession of 1991, the company attempted 
to reduce its total work force by 14,000 , again with substantial incentives for early retirement and voluntary departure (Clary 1991).

IBM's decision to make layoffs, thus, indicated a significant shift in the way America's biggest companies - once considered providers of secure jobs and stable careers - treated their employees. Seen in a broader context, however, what was truly remarkable was that the company had managed to do without layoffs for so long, while its peers had already jumped ship. In fact, waves of downsizing had swept through corporate America throughout the 1980s, eroding the sense of economic security for middle and working class Americans, what Paul Osterman (1999, p. 21) terms the "postwar institutional structure" of the labor market. This change has reflected a fundamentally new conceptualization of employment relations on the part of employers.

Of course, downsizing per se is nothing new. Even before the early 1980 s, firms laid off their employees during economic downturns. What alarmed many observers of the trend in corporate downsizing, around the time of IBM's layoff decision, was that, unlike in the past, even healthy companies were laying off employees. Scholars of industrial relations noticed a general change from downsizing primarily in times of economic downturn to downsizing in both good and bad times (Cappelli 1999; Osterman 1999). For instance, Eastman Kodak Company announced its plan to trim 10,000 jobs in the next two years. While the company had been consistently profitable, its institutional investors exerted heavy pressure for the company to increase its profit margins. Later in the same year, Xerox Corporation followed suit with a plan to cut more than 10,000 jobs or nearly 10 percent of its work force. Like Kodak, Xerox had been consistently profitable before the announcement, but it sought even higher profits through drastic cost-cutting measures. Its CEO explained: "To compete effectively, we must have a lean and 
flexible organization which can deliver the most cost-effective document-processing products and services" (Holusha 1993).

Also conspicuous recently when firms make their decision on downsizing is their intention to maintain, restore, and boost their financial performance — or more precisely their stock price. When Jonathan Schwartz, the new CEO of Sun Microsystems, announced on May 31,2006 that the company planned to cut 4,000 to 5,000 jobs in the next six months, he stated that the expected cost savings from the job cuts would help Sun meet analyst forecasts of a loss of 2 cents a share in the fourth quarter. Meeting analyst forecasts matters here, because stock price tends to decline when firms do not meet analyst forecasts, and this adversely affects both shareholders and executives holding stock options. This explains why the new CEO was so eager to ensure that the firm would meet analyst forecasts. As a matter of fact, analysts viewed the job cuts as the bare minimum and suggested that the cuts, which were largely expected, were already built into analyst forecasts (Flynn 2006).

This radical shift in the nature of downsizing disproves the simple economic interpretation that downsizing since the early 1980s represents a natural adjustment that can remove corporate inefficiencies amassed during the previous decades of economic prosperity (Baumol, Blinder, and Wolff 2003; Caves and Krepps 1993). Even in the early 1980s, large-scale workforce downsizing was dubbed as a last-ditch effort to save a gasping venture, but it has now become an "accepted way of managing, the norm rather than unusual, and the way of life (Budros 1997, p. 244). Companies argue that layoffs, in good times as well as bad, have become essential in an age of cutthroat competition (Murray 1995), but many critics have raised concerns about the harmful impacts downsizing has had on individual workers, their families and communities (Uchitelle 2006). How, then, has such a controversial practice as workforce 
downsizing come to be considered as business-as-usual? How does the sense of downsizing as an acceptable organizational practice emerge in the first place?

In this dissertation, I examine this transformation of workforce downsizing as a shareholder-value-management strategy since the 1980s, by tracing the histories of downsizing and analyzing its consequences for more than 700 large U.S. corporations during the period between 1981 and 2006. Building on previous sociological studies of downsizing, I find at work in the transformation a shift in ideology, from an emphasis on corporate growth to an emphasis on profitability and shareholder value, an ideology that both reflects and intensifies the influence the financial sector generally on firm behavior. Leading the change have been institutional investors in the stock market, who have come to control large blocks of stock of most U.S. firms since the 1980s, and corporate managers, who have become more receptive to the norm of shareholder primacy. Other stakeholders, workers and their unions in particular, have protested the growing influence of financial sector and the increasing tendency among major U.S. firms to downsize to boost profits, but my analyses show that their ability to resist these changes have been severely undermined by the political environment hostile towards labor unions. Nevertheless, my analyses also show that the contest among investors, managers, and workers over downsizing persist in the actual implementation of downsizing plans. In all, these findings illustrate the contested nature of institutional change, highlighting the role of agency and power in the process.

\subsection{PREVIOUS RESEARCH ON DOWNSIZING}

By all accounts, it is clear that corporate downsizing has become prevalent among large U.S. corporations since the early 1980s. What explains this increase in downsizing and, more 
important, its new use? Most existing economic studies on downsizing focus on its impact on corporate performance, but much fewer studies examine the causes of downsizing. Nevertheless, the findings of the economic studies pose an intriguing question, which is relevant to the present research. Most economic studies find that downsizing has a negative, rather than positive, effect on corporate performance measured as both operating and stock-market performance. What then explains the growing popularity of downsizing as a value-maximizing strategy? In this respect, I argue, existing economic studies on the causes downsizing fails to provide a convincing explanation. Sociological studies on the same issue provide a more promising explanation, but, as I will soon explain, that explanation has several limitations that need to be addressed.

\subsubsection{Economic Research on Downsizing}

There are a considerable number of studies on downsizing by economists, and some of them provide insight into the growing prevalence of downsizing since the 1980s. They predict that firms more engage in downsizing in order to restore or enhance their performance, but their empirical findings often defy this efficiency-based explanation of downsizing.

Causes of Downsizing. There are several economic explanations for the recent surge in downsizing activity among U.S. firms. First, firms downsize in response to declining operating performance (Baumol, Blinder, and Wolff 2003; Bluestone and Harrison 1982). According to these accounts, U.S. firms have continued to downsize even during good times, because of fierce foreign competition. Baumol, Blinder and Wolff (2003), using industry-level data, demonstrate that downsizing has been most prevalent in traditional manufacturing sectors where American companies have faced the severest competition from their foreign competitors. Another explanation for downsizing during profitable periods is that U.S. companies had become 'fat' 
through the 1960s and 1970s (Gordon 1996; Love and Nohria 2005). According to this explanation, during the takeover wave in the 1960s, U.S. firms expanded by acquiring or merging with other firms in industries unrelated to their core businesses (Bhagat, Shleifer, and Vishny 1990). The resulting conglomerate firms often had bloated managerial ranks (Caves and Krepps 1993). This conglomerate strategy prevailed among major U.S. firms throughout the 1960s and 1970s, but most conglomerate firms were plagued by poor performance and undervalued stock price (Berger and Ofek 1995; Comment and Jarrell 1995; Lang and Stulz 1994). In this context, downsizing can be understood ad an attempt by firms to reduce redundancies and to regain efficiency. Finally, new technologies may explain why even profitable firms engage in downsizing. With advanced technologies, firms can maintain productivity with fewer employees. What has been critical in this respect is the introduction of information technology. But there remains considerable controversy about whether technological innovations are the main reason for the increased rate of downsizing among U.S. firms. Hence, It is often argued that the impact of technological changes depends on how technological innovations are use (Fernandez 2001).

Consequences of Downsizing. If downsizing became prevalent because it enhances a firm's competitiveness and efficiency, as most economic studies assert, or because of technological innovation, performance should improve after downsizing. The evidence, however, is mixed at best (Datta, Guthrie, Basuil, and Pandey 2010). A number of studies examine firm profitability (mostly operating performance) subsequent to downsizing. While a few of these report improvement in profitability (Kang and Shivdasani 1997; Perry and Shivdasani 2005; Wayhan and Werner 2000), most studies find no evidence that downsizing improves long-term performance, or that it hurts firm profitability and reputations (Cascio, Young, and Morris 1997; 
De Meuse, Vanderheiden, and Bergmann 1994; Dougherty and Bowman 1995; Flanagan and O’Shaughnessy 2005; Guthrie and Datta 2008; Love and Kraatz 2009).

Studies of market reactions to downsizing announcements come to a similar conclusion. They find that such announcements tend to incur significantly negative reactions in the stock market (Hallock 1998; Lee 1997; Nixon, Hitt, Lee, and Jeong 2004; Worrell, Davidson, and Sharma 1991). In probably the first systematic investigation of the issue, Worrell et al. (1991, p. 674) suggest that layoff announcements generally convey negative information to investors, consistent with the notion that such announcements are viewed as a signal that a firm's financial troubles are real. Also interesting is Lee's (1997) study showing that the market seem to react more negative to downsizing in the United States even than in Japan, where downsizing is not widely accepted. These negative reactions are puzzling, given the claim of sociological studies that U.S. companies engage in downsize under the pressure from the financial market. The negative reactions from that very market require explanation.

To make sense of these unexpected negative findings, a few studies argue that the effect of downsizing is contingent on pre-downsizing conditions. Industry also seems to matter. First, Love and Nohria (2005) distinguishes between proactive and reactive downsizing. Reactive downsizing occurs when firms are compelled to downsize because their performance is already in decline, while proactive downsizing when firms downsize preemptively in the anticipation of difficult times in the future or in a bid to enhance their competitive standing. Love and Nohria show that only proactive downsizing leads to positive post-downsizing outcomes. Another study suggests that the impact of downsizing is contingent on industry characteristics; specificially, downsizing is more detrimental for firms in industries characteriszed by high R\&D intensity, high growth, low capital intensity, and high dynamism (Guthrie and Datta 2008). Finally, 
Palmon, Sun, and Tang (1997) suggest that the stock market reacts differently to downsizing announcements depending on the reasons provided for the decision to downsize. Specifically, downsizing announcements citing the firm's intention to improve profitability or efficiency tend to incurs positive reactions, whereas those citing poor market conditions negative reactions. Interesting, however, in both cases, downsizing does not improve the firms' long-term profitability. Downsizing has a significantly negative effect on the long-term profitability of the former group, and so does it, to a lesser degree, for the latter group.

Critique of Economic Research on Downsizing. Although existing economic studies shed light on the prevalence of downsizing, they are limited in several crucial ways. First, the thesis that downsizing has become prevalent as firms attempt to restore declining performance may explain downsizings in the early 1980s, when the U.S. economy was hard hit by a severe recession. It may not, however, adequately explain downsizings under improved economic situations in the 1990s. Second, if the prevalence of downsizing reflects potential efficiency gains or equivalently potential cost savings through elimination of redundancies or application of new technology, downsizing should lead to a significant improve in corporate performance, which, as reviewed above, often does not occur. The contingency argument provides a more nuanced account of why downsizing does not always improve performance. But it still does not explain why many firms that are unlikely to benefit from downsizing continue to engage in downsizing. Furthermore, the contingency argument raises a more fundamental issue. It suggests that only proactive downsizing leads to a significant improvement in corporate performance. But the very notion of proactive downsizing, that profitable firms should also downsize in order to further enhance their profitability, is a novel conception that was unheard of before the 1980s. Back then, firms downsized reactively as a temporary measure during economic downturns. Why 
and how has it become legitimate for firms with even healthy profits to cut jobs in a massive scale? There should be more than mere economic calculations involved in the transformation.

\subsubsection{Sociological Research on Downsizing: A New Paradigm of the Firm}

Most economic studies do not adequately explain the changed nature of downsizing, mainly because of the asociological assumption that the orientation of firms remains constant. Organizational institutionalists challenge such a notion and argue that "institutional frameworks define the ends and shape the means by which interests are determined and pursued" (Scott 1987, p. 508). Building on this crucial insight, an alternative sociological perspective of the firm maintains that, to understand corporate behavior, one has to start off examining firms' institutional contexts at a specific historical moment, suggesting that what is counted as imperative when a firm makes key strategic decisions varies in different contexts (Davis, Diekmann, and Tinsley 1994; 1997; Dobbin and Dowd 2000; Fligstein 1990; 1996; Mizruchi, Stearns, and Marquis 2006).

Similarly, the changed nature of recent downsizings should be understood within the changed institutional environment of the firm since the 1980s. As the prosperity of the postwar years came to an end in the 1970s, culminating in stagflation and bear markets, many large U.S. companies experienced a chronic decline in their market share and profitability. This stimulated emerging power groups in financial markets to search for a remedy. Leading the charge were institutional investors, such as large public pension and mutual funds. In a social-movement-like fashion, they began to challenge management of leading U.S. firms and promoted the new financial orthodoxy that the only legitimate goal of corporations is to maximize returns to their shareholders - the shareholder-value paradigm of the firm. As a result, firms have come under 
increased pressure from financial markets to boost profits and thus stock price. The prevalence of downsizing is indicative of this paradigm shift within the corporate sector since the 1980s. In fact, many prominent scholars of industrial relations as well as sociologists attribute the change to the norm of shareholder primacy (Appelbaum and Batt 1994; Budros 1997; 2000; 2002; Cappelli 1999; Fligstein and Shin 2007; Hirsch and De Soucey 2006; Kochan forthcoming; Lazonick and O'Sullivan 2000; Osterman 1999).

There are several sociological studies that empirically test the claim that financial market pressure might have driven the emergence of the new downsizing, but their evidence seems less than conclusive. In a series of studies using data on Fortune 100 firms from 1979 to 1994 , Budros $(1997 ; 2000 ; 2002)$ demonstrated that decline in shareholder value (measured as percentage change in a firm's stock price) triggered corporate downsizing. Using industry-level data, Fligstein and Shin (2007) also showed that industries with low profits relative to assets were more likely to engage in layoffs. Like most economic studies, they demonstrate that declining performance leads to downsizing but then argue that pressure from the financial community may explain such a relationship. It is also likely, however, that poor performance may induce firms to voluntarily downsize. In addition, similar patterns have also been observed in contexts where shareholder-value orientations have not been central, such as Japan in the 1980s (Kang and Shivdasani 1997). Although it does seem likely that the shareholder-value paradigm has brought about the new form of downsizing, it still remains unclear by what processes this has occurred.

\subsection{SOCIO-POLITICAL ACCOUNT OF THE TRANSOFRMATION OF DOWNSIZING}


Despite their contributions to our understanding of the changed nature of downsizing, however, previous sociological studies have significant limitations. There are two broad issues. The first one is that of agency: who in the financial markets have pushed firms to downsize? The usual suspects are institutional investors, who have become dominant players in financial markets in the U.S. as well as abroad (Davis and Thompson 1994; Dobbin and Zorn 2005; Useem 1996). But pressure from institutional investors alone may not explain the growing tendency among leading U.S. firms to downsize; in any case, it is executives who should make the final decision. Hence, it is important to sort out agents of financial capitalism within the firm and to see how they respond to external pressure. Another important issue is how other stakeholders, workers and labor unions in particular, have responded to the change. When firms engage in downsizing, workers are the ones who suffer the most. Furthermore, the fact that even profitable firms now downsize to further enhance profits should generate bitter feelings among workers. Nevertheless, few studies have examined whether and how resistance from workers and their unions prevent firms from engaging in downsizing. During the postwar years, labor unions had some control over how firms adjust their workforce in response to economic hardship. The prevalence of downsizing since the 1980s suggests that unions have lost their control over the process, but why and how?

My dissertation addresses these issues and provides a socio-political account of the transformation of downsizing as a shareholder-value strategy, involving both the role of institutional investors and shareholder-value oriented managers in promoting downsizing and the resistance from labor unions. My socio-political account draws on two recent approaches in the institutional literature - the institutional approach to power and institutional pluralism. The first approach emphasizes the role of power and interest group politics in the process of 
institutionalization. Early work of organizational institutionalists has been criticized because of its lack of attention to the role of power and agency (DiMaggio 1988; Mizruchi and Fein 1999; Perrow 1986; Powell 1991). In response, later work attempts to incorporate the role of power and agency, particularly to explain institutional change. Hence, it is argued that shifts in a firm's institutional environment, such as the rise of the shareholder-value paradigm, do not automatically affect its strategy; instead, the ultimate outcome is crucially dependent on the power struggle among the firm's external as well as internal constituents (Davis, Diekmann, and Tinsley 1994; Dobbin and Dowd 2000; Fligstein 1990; Roy 1997). It is important here to reiterate that power relations among these constituents themselves are affected by shifts in institutional arrangements; in short, power and interest are also institutionally constructed (Dobbin and Jung 2012).

Another important recent approach in the institutional literature is institutional pluralism. While early institutional work assumes the presence of one dominant institutional logic, later work challenges the resulting imagery of a homogeneous institutional field governed by one dominant logic within a given place or time (Fligstein 1990; Haveman and Rao 1997; Ocasio and Kim 1999; Ruef and Scott 1998; Thornton and Ocasio 1999). Instead, later work sees institutional fields as composed of multiple institutional logics. The original insight comes from Friedland and Alford's widely-cited work in 1991. They suggest that there are multiples institutions in the western capitalist world, including capital market, bureaucratic state, democracy, nuclear family, and Christian religion. As these multiple institutions often shape individual preferences and organizational interests in contradictory ways, they tend to generate tensions among individuals or organizations with competing preferences and interests, which become the primary driver of institutional (Clemens and Cook 1999; Seo and Creed 2002; 
Stryker 2000). Subsequent studies have demonstrated how the presence of multiple institutional logics politicizes the process of institutional diffusion (Ahmadjian and Robbins 2005; Fiss and Zajac 2004; Greenwood et al. 2010; Hoffman 1999; Ingram and Rao 2004; Marquis and Lounsbury 2007).

Although these two developments - the attention to the role of power and interest group politics and the emphasis on institutional pluralism—-have emerged rather separately by different groups of institutionalists, they share lots of common assumptions and are intimately related with each other. On the one hand, the content and intensity of interest group politics should be crucially determined by the availability of multiple institutional logics. According to the institutional approach to power, the influence of different interest groups is not given but shaped by higher social orders (Jepperson 1991; Scott 1987). Hence, without logics that sharply define group interest, interest group politics is unlikely to intensify to the point that triggers significant institutional change. On the other hand, by the same token, the presence of multiple logics does not mean much unless there are carriers of different logics. Histories are full of examples where out-of-dated causes or ideas became revitalized as new social groups mobilized them to advance their economic and political interests (Blyth 2002; Campbell 2004).

In this dissertation, I attempt to synthesize these two approaches in order to construct a socio-political account of the transformation of downsizing. I attend to the role played by three interest groups in the process-corporate managers, institutional investors, and labor unions, who promote competing institutional logics about the firm-employee relationship. Institutional investors, the primary promoter of the shareholder-value paradigm, have pushed firms to downsize if that helps boost corporate performance. In contrast, labor unions, the primary defender of industrial unionism and the business-labor social contract, have tried to prevent 
downsizing for profit maximization. Finally, managers initially resisted the logic of shareholder primacy but have thus become increasingly receptive to the logic. In three separate but closely related chapters, I explore how this inter-class power struggle over definition of the legitimate form of downsizing unfolds. In the first chapter, I examine the role of institutional investors in pushing for downsizing to maximize shareholder value, and why managers have become more receptive to such demand from investors. In the second chapter, I examine how labor unions have resisted the spread of downsizing and how the anti-union stance of the U.S. government in the 1980s undermined unions' power to resist the change. These two chapters together tell the story of how the rise of shareholder primacy has shifted the balance of power between investors and workers and thereby has led to a radical reconceptualization of the firm-employee relationship. But the last chapter, however, demonstrates the lingering political tension over the transformation of downsizing among investors, managers, and workers. It examines the implementation of announced downsizing plans and demonstrates the contrasting influences of the three groups over the pace and intensity of downsizing.

\subsection{RESEARCH DESIGN}

To demonstrate the validity of my socio-political account, I examine the roles of institutional investors, corporate managers, and labor unions in (1) downsizing announcements, and (2) the actual implementation of announced downsizing plans. The research design for my dissertation has a number of important advantages over previous studies of downsizing. First, while many previous studies of corporate downsizing were done at the industry level, my dissertation project focuses on firm-level dynamics. This has been done by tracing the complete histories of 
downsizing announcements for more than 700 large U.S. corporations between 1981 and 2006; altogether, more than 6,000 announcements have been identified thorough archival search.

Second, I analyze both downsizing announcements and the actual implementation of the announced downsizing plans. This research design has two merits. Methodologically, it addresses the thorny measurement issue of whether the proper measure of downsizing is the intention to downsize or the actual reduction in the number of employees. Announcements of downsizing may not lead to an actual workforce reduction, but an actual headcount reduction may result from other events, such as divestiture. The present research avoids this problem by examining both in two separate analyses. Furthermore, any possible discrepancy between downsizing announcements and actual implementation is more than measurement error; it itself merits some theoretical explanation. Institutional theory suggests that such a decoupling is prevalent when organizational action is driven by external pressures (Meyer and Rowan 1977). Hence, I expect that if firms engage in downsizing activities in response to pressures from the financial community, decoupling of actual implementation from announcements of downsizing will be prevalent.

Third, for the actual implementation of announced downsizing plans, I have collected detailed information about workforce size and composition at the establishment level rather than at the firm level. Information is obtained from the annual "EEO-1" reports that private sector establishments submit to the Equal Employment Opportunity Commission (EEOC). These reports identify the location and industry in which each establishment operates and break down annual employment by nine job categories - (1) managers and officers, (2) professionals, (3) technicians, (4) sales workers, (5) administrative support workers, (6) craft workers, (7) operatives, (8) laborers and helpers, and (9) service workers. This feature of my research design 
will enable me to examine another important issue: whether the impact of downsizing varies across different occupational groups — especially for white-collar jobs and blue collar jobs. I have matched the data from EEO-1 reports with firm-level data from other sources. The use of these varied sources enables me to construct a comprehensive data set containing information on both financial and workforce status of the largest U.S. companies over a period of more than twenty years.

\subsection{DATA}

The initial sample included 789 large U.S. companies that were traded between 1965 and 2006. The sampling frame is Fortune's list of America's largest firms, supplemented by information from Dun's Million Dollar Directory for selected industries. We stratified the sample by industry, selecting a roughly equal number of firms from 23 industries. ${ }^{1}$ The majority of industries (16 out of 23) were sampled exclusively from the Fortune Industrial 500. Some sectors, however, such as communications, utilities, transportation, wholesale and retail, service, health care, and entertainment, are not included in this list. For entertainment and health care, we used Dun \& Bradstreet's Million Dollar Directory for years before 1983, at which point Fortune began to cover these industries.

Whereas most longitudinal datasets are sampled in a single year (typically at the midpoint), my collaborators in data collection and I sampled firms evenly across the entire period so as to achieve a more representative group of firms, and so as to include both firms and industries on the rise as well as those in decline. We sampled systematically, within industries,

\footnotetext{
${ }^{1}$ These are aerospace, apparel \& leather, automobile and transportation equipment, building materials, chemicals, communications, computer, electrical equipment, entertainment, food, healthcare, machinery, metal \& metal products, mining, oil extraction \& construction, paper \& wood products, petroleum refining, pharmaceutical, publishing, retail \& wholesale, service, textile, transportation, and utilities.
} 
with replacement when a firm already appeared in the sample. For every other sampling year starting in 1965 and ending in 2005, we drew two names from half of the industries, and one name from the other half. I enlarged the sample size by repeating the procedure for every other sampling year between 1966 and 2006 to draw one name from half of the industries. In a few cases (e.g., computers in the mid-1960s) we could not fill a cell and so left it empty. After eliminating foreign subsidiaries and firms whose data were not available in Compustat (the principal source for basic financial information), the final sample contained 789 firms. For this dissertation, I use data on 714 firms that existed between 1981 and 2006.

\subsection{STRUCTURE OF THE DISSERTATION}

The following three empirical chapters explore the role of agency and power in institutional change, by examining the role of competing interest groups in the transformation of downsizing as a shareholder-value strategy. The first chapter examines the role of institutional investors and shareholder-value-oriented managers in the transformation. The second chapter examines the potential resistance from labor unions and shows how the anti-union stance of the public policy regime in the 1980s weakened unions' power to resist. Finally, the last chapter addresses the issue of implementation. In the first and second chapters, I examine downsizing announcements, but it should be equally important whether and how they are actually implemented. The last chapter demonstrates the contested nature of the implementation process, by showing the contrasting roles of investors, managers, and unions. 


\section{THE TRANSFORMATION OF WORKFORCE DOWNSIZING AS A SHAREHOLDER-VALUE STRATEGY}

Since the passage of the Employee Retirement Income Security Act of 1974, pension assets for both private and public sector employees have flooded into the equity market, turning institutional investors in charge of those assets into controlling shareholders of large U.S. companies (Gourevitch and Shinn 2005, p. 47; Useem 1996). In pursuit of greater returns, institutional investors have begun to challenge corporate management and have brought about a new paradigm for how firms should be run, based on the notion that the sole goal of publiclytraded companies is to maximize returns to shareholders (Fligstein and Markowitz 1993). Organizational institutionalists have long emphasized the importance of dominant management paradigms, or what Neil Fligstein, a prominent institutionalist, terms conceptions of control, which not only define what constitutes the right relations among key stakeholders but also determine whose interests should be given priority (Dobbin and Dowd 2000; Fligstein 1990; 2001). ${ }^{2}$ The rise of the shareholder-value paradigm in the 1980s in particular has had profound implications for class dynamics in the American workplace-for example, an unequal distribution of power and wealth between owners and workers in favor of the former (Fligstein and Shin 2004; Tomaskovic-Devey and Lin 2011).

One indication of the rise of the shareholder-value paradigm is the increasing prevalence of workforce downsizing (Kalleberg 2009). Workforce downsizing has not only become more prevalent (Baumol, Blinder, and Wolff 2003), but its nature has changed. Previously, firms laid employees off temporarily to adjust workforce size during downturns (Kochan, Katz, and McKersie 1994). Since the early 1980s, however, firms have increasingly cut jobs permanently

\footnotetext{
${ }^{2}$ Hereafter, I use management paradigms and conceptions of control interchangeably.
} 
in both good and bad times, as a strategy to maximize profits (Appelbaum and Batt 1994;

Cappelli 1999; Osterman 1999). Previous studies by organizational sociologists have linked this new form of downsizing to the rise of the shareholder-value paradigm (Budros 1997; 2002; Fligstein and Shin 2007; Hirsch and De Soucey 2006; Useem 1993), but evidence of this link has not yet been conclusive. A study by Budros (1997), arguably the best empirical work on this issue thus far, shows that a decline in a firm's stock price triggers downsizing, suggesting that pressure from shareholders for greater returns induce firms to downsize. Similar patterns, however, have also been observed in contexts where shareholder-value orientations are not widely accepted, such as Japan in the 1980s (Kang and Shivdasani 1997). Although it does seem likely that the shareholder-value paradigm has brought about the new form of downsizing, it still remains unclear by what processes this has occurred.

In this paper, I aim to develop a fuller account of how the shareholder-value paradigm has promoted the new form of workforce downsizing. This account has two components. First, building on resource dependence theory, I suggest a mechanism of coercion operating through the power of external resource providers to impose their preferred management paradigms upon firms (Pfeffer and Salancik 1978; Prechel and Morris 2010). Since the 1980s, large U.S. companies have become increasingly dependent on institutional investors for capital flow. Because of this resource dependence relationship, they have become vulnerable to institutional investors' demands for greater returns, which may induce them to downsize more frequently (Useem 1996). This kind of resource dependence argument has been frequently made but rarely directly tested. In this paper, I provide a thorough empirical test for the argument. In conducting this test, however, I find that the resource dependence argument does not hold in its simple form; that is, not all institutional investors are equally capable of pressuring firms to downsize. Instead, 
I show that only blockholding institutions (those that hold a large block of a firm's stock) or pressure-resistant institutions (those that invulnerable to counter-pressure from corporate managers) can exert significant influence over firms' decision to downsize.

My second and equally important claim provides a mechanism of persuasion encouraging managerial embrace of the shareholder-value paradigm. Even taking into account the different levels of influence that different types of institutional investors hold, external pressure from institutional investors alone is unlikely to explain the increasing prevalence of downsizing. In the end, it is managers who make the decision to downsize, and they tend to resist external pressure, especially when it comes to strategic decisions such as downsizing (Oliver 1991). Before the 1980s, managers engaged in downsizing only reluctantly (Budros 1999, p. 78), given that, at the time, expanding the size of a firm was the hallmark of successful management. The recent prevalence of downsizing suggests that managers now have somehow embraced the shareholdervalue paradigm and have actively engaged in downsizing in order to enhance share price. Hence, building on Fligstein's $(1990 ; 2001)$ theory of conceptions of control, I suggest a second mechanism that encourages managers to embrace the shareholder-value paradigm. Shifts in the dominant management paradigm reshape the behavior of managers, I argue, by changing the context in which managers make important decisions, which I term decision context. In the present case, the rise of the shareholder-value paradigm has led to a new decision context in which managers have stronger incentives to maximize shareholder value. Crucial to constructing such a decision context has been a set of prescriptions for reforming corporate governance, prescriptions which were originally formulated by agency theorists in financial economics and which were thereafter promoted by the financial community (Dobbin and Jung 2010). 
My analysis of downsizing announcements, drawing on a sample of 714 large, publiclyheld companies between 1981 and 2006, shows that both the pressure from institutional investors and the new decision context encouraged firms to downsize more frequently. By demonstrating the role of institutional investors in promoting downsizing as a shareholder-value strategy, especially blockholding and pressure-resistant ones that are likely to overcome resistance from corporate managers, my findings emphasize the importance of agency and power in institutional change. At the same time, my findings about the new decision context also suggest that change agents themselves are socially constructed by the prevailing management paradigm. Managers initially resisted shareholder primacy, but within the changed decision context, they have become agents of shareholder value and in the process have reinvented workforce downsizing as a solution to managing shareholder value and sending to investors their commitment to increasing value.

\subsection{WORKFORCE DOWNSIZING AS A SHAREHOLDER-VALUE STRATEGY}

During the 1980s and 1990s, the postwar business-labor social contract disintegrated. This was important because prior to this disintegration, employees of large American companies in primary business sectors had enjoyed a fairly high degree of job security and career stability (Kalleberg 2009). Before the 1980s, employers and unions had set the rules governing various aspects of employment relations, including wages, benefits, working hours, and job descriptions (Kochan, Katz, and McKersie 1994). These informal rules, however, had come under severe strain beginning in the late 1970s (Osterman 1999). Faced with fierce foreign as well as domestic competition, U.S. companies experienced a severe drop in profitability and thus were less willing to make concessions to labor. In addition, automation and computerization had begun to replace 
human labor, thus further weakening the bargaining power of labor unions. In addition to these changes, the norm of shareholder primacy accelerated the collapse of the postwar business-labor social contract. Employers attempted to drastically revamp their postwar employment practices in the interest of maximizing shareholder value (Batt and Appelbaum 2010; Jacoby 2008; Kochan forthcoming).

The prevalence of downsizing is one prominent indication of the revamping of postwar employment practice driven by the norm of shareholder primacy (Osterman 1999). In the changed economic and political context since the 1980 s, which has been characterized by the growing influence of investors who demand maximum returns on their investment, workforce downsizing has become reconstructed as a means to enhance a firm's stock price (Budros 1997; 2002; Fligstein and Shin 2007; Lazonick and O'Sullivan 2000). In a book that popularized the business-process-reengineering movement, Hammer and Champy (1993) championed downsizing as an effective means to eliminate non-value adding work and thus to achieve immediate cost savings. Allured by this prospect, poorly-performing firms have engaged in massive workforce downsizing in order to achieve a quick turnaround, even though the likelihood of such a turnaround was very low (Cascio, Young, and Morris 1997; De Meuse, Vanderheiden, and Bergmann 1994; Guthrie and Datta 2008; Love and Nohria 2005).

Moreover, even well-performing firms do downsize to boost share price and satisfy shareholders (Cappelli 1999; Osterman 1999). In 1997, Kimberly-Clark eliminated 5,000 jobs in a bid to push the company closer toward achieving management's goal of doubling earnings per share between 1995 and 2000 (Langreth 1997). In another example, Dell Computer, after failing to meet Wall Street analysts' earnings forecasts for the fourth fiscal quarter of 2000 (it earned 18 cents per share while securities analysts had expected 25 cents per share), announced its 
intention to cut 1,700 jobs to improve profit margins (Gaither 2001). In yet another example, Alcoa planned to cut 6,700 jobs in 2006; while the company made record earnings in the first three quarters of that year, the CEO stated that the company needed to take the "difficult but necessary" steps to move forward (Glader 2006).

\subsection{TWO EXPLANATIONS: RESOURCE DEPENDENCE AND DECISION CONTEXT}

What accounts for this transformation of downsizing as a shareholder-value strategy? Both resource dependence theory and Fligstein's theory of conceptions of control provide crucial explanations. Resource dependence theory suggests that firms' growing dependence on institutional investors for capital flow makes them susceptible to those investors' demand for greater returns on their investment, which may induce them to downsize more frequently. Further developing this explanation, I suggest that such pressure from institutional investors is most effective when they are blockholders and resistant to counter-pressure from corporate managers. Fligstein's theory of conceptions of control provides a second explanation. It suggests that shifts in the dominant conception of control reorient the behavior of managers. Further developing this explanation, I argue that such reorientation in managerial behavior can occur because of a change in decision context. In this case, proponents of the shareholder-value paradigm have changed the decision context in a way that incentivizes managers to pursue strategies that enhance shareholder value, such as downsizing.

\subsubsection{Resource Dependence and External Pressure from Institutional Investors}

Resource dependence theory suggests that external resource providers can exert considerable influence over an organization (Pfeffer and Salancik 1978). The influence that one organization 
can exert over another is defined as a function of the latter's dependence on the former for critical resources (Emerson 1962). Capital dependence theory, a variant of resource dependence theory, applies this fundamental argument to the analysis of the modern corporation, focusing on “corporations' historically contingent capital-dependent relationship to the political, economic, and ideological dimensions of their institutional environment" (Prechel 2000, p. 10). According to the theory, a crucial feature of capital dependence since the 1980s has been "the change from debt to equity financing" (Prechel and Morris 2010, p. 341; see also Davis and Mizruchi 1999). Heavy corporate reliance on equity financing has empowered institutional investors, who have come to control a large block of a firm's stock (Davis and Thompson 1994; Useem 1996). "This historical contingency," Prechel and Morris argue, "increased institutional investors' power, which in some respects made corporate management more vulnerable to external influences" (Prechel and Morris 2010, p. 341). Unlike banks, which are satisfied as long as a debt is repaid, institutional investors have pressured corporate management to enhance profits and stock performance, creating incentives for corporate managers to maximize shareholder value.

As a result, it is argued, firms may be more likely to conduct downsizing to enhance profits under the oversight of these investors (Useem 1996). Although few studies have directly tested this relationship between investor pressure and downsizing in the United States, Ahmadjian and Robbins's (2005) study of downsizing in Japan demonstrates that ownership by foreign institutional investors (mostly from the U.S.) significantly increases the rate of downsizing. If institutional investors exert influence abroad, they should have similar or even greater influence in the U.S., where the politico-legal environment is considered more permissive of job cuts (Weiler 1990). Other studies, however, suggest that there may be limits to the direct influence of institutional investors. While a firm's dependence on institutional investors may be a 
necessary condition for the latter's influence over the former, it may not be a sufficient one. For one thing, managers often resist or manipulate external pressure (Oliver 1991). Indeed, previous studies demonstrate that there is considerable variation across different types of institutional investors in terms of their ability to influence management.

There are two main sources of this variation. The first is the size of holdings. Some studies have cast doubt on the ability of institutional investors to impose substantive reforms on firms, for most of them hold only a small portion of a firm's stock and may thus be reluctant or unable to challenge management (Coffee 1991; Davis and Kim 2007). Instead, it is suggested, only blockholding institutions have both the power and incentive to challenge managers (Hartzell and Starks 2003; Shleifer and Vishny 1986; Tosi and Gomez-Mejia 1989). In addition, unlike smallholders, blockholders cannot simply vote with their feet when dissatisfied with management, because it is hard to liquidate large chunks of shares without further depressing stock value (Coffee 1991; but see also Davis 2008). Hence, when stuck with an underperforming firm, blockholding institutions are often left with only one option, that is, pressuring managers to restore profitability. Such pressure may encourage managers to downsize.

Hypothesis 1-1: Ownership by blockholding institutions will increase the rate of workforce downsizing.

The second main source of variation is institutional investors' vulnerability to countpressure from corporate managers. Some institutions are pressure-sensitive, i.e., vulnerable to such pressure, while others are pressure-resistant. One important factor determining their vulnerability is an institutional fund manager's current or potential business ties to firms. Investors with such ties are unlikely to challenge management (Brickley, Lease, and Smith 1988; Coffee 1991; David, Kochhar, and Levitas 1998; Davis and Kim 2007). For instance, 
commercial banks and insurance companies are least willing to challenge corporate management, because they may lose business with the firms (Coffee 1991). Mutual funds have a similar conflict of interest; for instance, some mutual funds (e.g., Fidelity) sell pension instruments to companies (Davis and Kim 2007). Unlike these other institutions, public pension funds have almost no opportunity to earn fees or income from companies. Hence, they have been most active in pressuring management, sponsoring anti-management proxy proposals and pressuring managers through private negotiations (Carleton, Nelson, and Weisbach 1998; Del Guercio and Hawkins 1999; Gillan and Starks 2000). I expect that although they may not always directly pressure firms to downsize, their demand for greater returns on their investment can still encourage downsizing.

Hypothesis 1-2: Ownership by pressure-resistant institutions (i.e., public pension funds) will increase the rate of workforce downsizing.

These two hypotheses concerning the influence of blockholding and pressure-resistant institutions suggest that smallholding and pressure-sensitive institutions are unlikely to have a similarly positive influence over downsizing. In fact, I note, such institutions might even be expected to have a negative influence. Without having much influence over management, they typically choose to divest at the first sign of poor management. One study examining institutional investors' reaction to announcements of a forced CEO turnover shows that such investors sell even before such announcements are actually made (Parrino, Sias, and Starks 2003). Although downsizing may improve a firm's profitability in the near future, it can also have an immediate negative effect on the firm's earnings and thus its stock price, because downsizing often necessitates significant restructuring costs, such as lump-sum severance payments. Hence, if smallholding and pressure-sensitive institutions sell even before downsizing 
plans are publicly announced, the resulting sudden drop in ownership by such institutions can generate a spurious negative relationship between their ownership and the rate of downsizing.

\subsubsection{New Decision Context and Reorientation of Managerial Behavior}

While resource dependence theory provides a coercive mechanism for downsizing, through pressure from institutional investors, Fligstein's $(1990 ; 2001)$ theory of conceptions of control provides an additional explanation of persuasion, through reorientation in managerial behavior towards shareholder-value maximization. Fligstein posits that, at each historical moment, there is a dominant model of the firm, one that defines the right relationship among key stakeholders and appropriate strategies that firms should pursue in the interests of these stakeholders. Fligstein (1990) further suggests that shifts in the dominant conception of control reorient the behavior of firms and managers. For example, he shows that the shift from a conception of control that views the firm as a production function to a conception that views the firm as a portfolio of investment gave rise to a growth strategy through diversification in the 1960s and 1970s. This strategy was largely abandoned in the 1980s, however, when the viability of the firm-as-portfolio model was severely undermined by the newly emergent financial doctrine that investors, not firms, should diversify (Davis, Diekmann, and Tinsley 1994).

But how do shifts in the dominant conception of control change the behavior of managers? Fligstein argues that such change occurs through intra-firm power struggles among managerial groups with different strategic orientations. A shift in the dominant conception of control tends to change intra-firm power bases of different groups, pushing those with strategic orientations most congruent with the prevailing conception of control to the top (Fligstein 1987; Ocasio and Kim 1999; Thornton and Ocasio 1999). Fligstein's studies show that the firm-as-the-portfolio 
model favored managers with a background in finance, who came to control many prominent companies and actively pursued the diversification strategy in the 1960s and 1970s (Fligstein 1985; 1987; Fligstein and Brantley 1992). The decline of the firm-as-portfolio model, however, weakened the intra-firm power base of financial managers, which led to the abandonment of the diversification strategy (Ocasio and Kim 1999).

Building on Fligstein's explanation, I suggest that a shift in the dominant conception of control can also occur through the efforts of external groups to change the decision context in which managers make and implement key strategic decisions. I argue that this better explains how the rise of the shareholder-value paradigm has reshaped the behavior of managers in general and their behavior with respect to downsizing in particular. Differing from previous shifts in the dominant conception of control, the primary tension resulting from the shift to the shareholdervalue conception was not among internal agents (i.e., managers) but between agents and principals - that is, managers who were mostly interested in enlarging the size of firms and shareholders who wanted maximum returns on their investment. As the prosperity of the postwar years came to an end in the 1970s, culminating in stagflation and bear markets, many large U.S. companies experienced a steady decline in their market share and profitability. This stimulated emerging power groups in financial markets, e.g., institutional investors, to search for a remedy. These external groups promoted new corporate strategies for enhancing profitability and share price (Davis et al. 1994; Useem 1996; Zorn et al. 2004; Zuckerman 2000). They imposed such strategies upon management using their market power, but they also did so by changing the decision context in a way that induced managers to pursue profit maximization, and thus to implement many of those new strategies, including downsizing. 
Agency theory, a branch of financial economics, has played an important role in constructing this new decision context. Agency theorists argue that managers, who typically hold little stake in the firm, have insufficient incentive to maximize profit (Fama 1980; Jensen and Meckling 1976). In the 1960s and the 1970s, they were busy diversifying their firms to expand the size of their empires and to raise their salaries, without increasing shareholder wealth (Amihud and Lev 1981; Jensen 1986). Agency theorists not only diagnosed these problems but also provided ready remedies, by means of practitioner outlets such as Harvard Business Review (e.g., Jensen $1984 ; 1989)$ that contributed to the theory's ascendance in the financial community. Agency theorists called for broader governance reforms to ensure that managers would pursue value maximization.

Three such reforms became prominent. First of all, to minimize agency costs, agency theorists prescribed that managers should become owners: "If the manager of a firm owned 100 percent of the firm's shares, then ... the decisions made by that manager would be presumed to be those that maximize long-run shareholder value ..." (Jensen, Murphy, and Wruck 2004, p. 21). While this is practically impossible, the board still can tie the wealth of the firm's executives to that of shareholders, for instance by granting executive stock options (Jensen and Murphy 1990). Agency theorists also attributed the agency problems of the 1960s and the 1970s to the failure of an internal monitoring system - the board of directors (Jensen 1993, p. 862). As a remedy, they called for boards to be composed mostly of outside directors. Finally, agency theorists argued that firms should increase financial transparency, so that investors could assess their prospects (Jensen et al. 2004). For that purpose, management consultants advised firms to have a financial specialist on the top management team - a chief financial officer (Zorn 2004). 
Existing studies point to the importance of academic theories in shaping the behavior of managers (Khurana 2007; Strang and Meyer 1993). Performativity theory, for instance, suggests that market participants perform their roles as set out by theories they believe in (Callon 1998; Mackenzie and Millo 2003). Although it is unlikely that firms in this case have simply performed according to agency-theory prescriptions, all three agency-theory prescriptions mentioned above have been widely adopted. Since the 1980s, executive compensation has steadily increased, and much of the increase has been driven by stock options (Dobbin and Jung 2010; Yermack 1995). There have also been significant improvements in board monitoring in that most boards are now dominated by outside directors (Gordon 2007). Finally, by the end of the 1990s, most Fortune 500 firms had hired a CFO or similar executive (Rao and Sivakumar 1999; Zorn 2004).

One reason that corporations have embraced agency-theory prescriptions is that institutional investors have actively advocated for them. While they have put direct pressure upon firms to boost profits, they have also been interested in improving the broader corporate governance structure of firms, by pushing for a set of agency-theory prescriptions (Dobbin and Jung 2012). Public pension funds have led the charge, sponsoring an array of shareholder proposals to improve board governance, executive compensation, and financial transparency (Carleton, Nelson, and Weisbach 1998; Gourevitch and Shinn 2005). For instance, in 1985, the California Public Employees' Retirement System (CalPERS) led the Council of Institutional Investors (CII), bringing together public, private, and union fund managers, whose "shareholder bill of rights" called for greater shareholder input to reduce agency costs (Jacoby 2007). As firms have adopted these agency-theory prescriptions, they have constructed a decision context in which stock-price-enhancing actions are rewarded, while stock-price-reducing ones are punished. 
I argue that in this changed decision context, workforce downsizing has become an accepted strategy to enhance stock price. Previous studies have shown that equity-based compensation practices create incentives for managers to pursue profit maximization (Burns and Kedia 2006; Efendi, Srivastava, and Swanson 2007; Sanders and Hambrick 2007; Zhang et al. 2008). Hence, firms with option-loaded chief executives may be likely to engage in downsizing more frequently as they aim at greater profits. Studies have also shown that independent boards are more likely to fire CEOs of poorly-performing firms and replace them with outsiders (Huson, Parrino, and Starks 2001; Weisbach 1988). Managers may thus become more conscious of profit maximization under the monitoring of independent boards, which in turn may induce them to downsize. Finally, whereas financial managers used to perform back-office functions like bookkeeping and preparation of tax documents, as CFOs they are deeply involved in making key strategic decisions. As cost experts, they have pushed for strategies that, they believe, cut costs and thereby boost profits. Workforce downsizing is one such strategy.

Hypothesis 2-1: Stock option grants to CEOs will increase the rate of workforce downsizing. Hypothesis 2-2: Board independence will increase the rate of workforce downsizing.

Hypothesis 2-3: The presence of a CFO will increase the rate of workforce downsizing.

\subsection{DATA AND METHOD}

To test my arguments, I analyze downsizing announcements made by 714 large publicly-held U.S. corporations from 1981 to 2006, using a continuous-time event history analysis, which uses a fine-grained duration measure, and thus is better able to capture temporal dynamics than a discrete-time model. I utilize a fixed-effects version of the Cox model, the Cox model with stratification on subjects (Allison 1996). The Cox model is a widely used method for continuous- 
time event history analysis, and the fixed-effect estimator allows more rigorous causal inferences by controlling for unobserved firm-specific characteristics that are stable over time. I assemble a comprehensive set of variables that are known to affect a firm's decision to downsize. In particular, previous studies show that most firms downsize reactively, in response to declining profitability or stock price (Budros 1997). My analysis demonstrates the proactive nature of recent workforce downsizings; even after controlling for prior financial performance, pressures from shareholder groups and shareholder-value prescriptions significantly increase the rate of workforce downsizing.

\subsubsection{Sample}

The original sample included 789 large U.S. companies that were traded between 1965 and 2006. Most longitudinal studies of large firms use samples drawn in a single year (typically at the midpoint). Studies based on such samples may suffer from survivorship bias, because these samples become biased toward successful firms in later years. To overcome this problem, my collaborators in data collection and I sampled firms evenly across the entire period so as to include firms in growing as well as declining industries. We sampled systematically, within industries, with replacement when a firm already appeared in the sample. The sampling frame is Fortune's list of America's largest firms, supplemented by information from Dun's Million Dollar Directory for selected industries. We stratified the sample by industry, selecting a roughly equal number of firms from 23 industries. ${ }^{3}$ The majority of industries (16 out of 23 ) were sampled exclusively from the Fortune Industrial 500. Some sectors, however, such as communications, utilities, transportation, wholesale and retail, service, health care, and entertainment, are not included in this list. For entertainment and health care, we used Dun \&

\footnotetext{
${ }^{3}$ See Footnote 1.
} 
Bradstreet's Million Dollar Directory for years before 1983, at which point Fortune began to cover these industries. For the present study, I use data on 714 firms that were publicly traded between the third quarter of 1981 and the fourth quarter of 2006.

\subsubsection{Dependent Variable: Downsizing Announcements}

I collected information on the history of downsizing announcements for the 714 firms in my sample between 1981 and 2006. Following Budros (1999), I define downsizing as permanent personnel reduction. This definition excludes announcements of temporary layoffs and sales of assets. Data on downsizing announcements were obtained through extensive archival search. The primary source was the Lexis/Nexis electronic database. The database catalogues most major newspapers, such as The Wall Street Journal and The New York Times, and several newswire services. Rather than limiting sources to one or two major newspapers-a tactic that previous studies have adopted-I used all possible sources, including local newspapers. Cases that referred to downsizing plans announced earlier were dropped. Ultimately, 5,843 announcements were identified. Some may question the validity of my measure of downsizing activity, because announcements of downsizing may not lead to actual workforce reductions (Budros 1997, p. 235-36). To check the validity of my measure, I analyzed whether firms actually implemented their announced downsizing plans. The result shows that after announcing their downsizing plans, firms, on average, reduced their workforce size by about 3.3 percent. More than 60 percent of firms that announced a downsizing plan in the previous year reduced their workforce by at least one percent.

\subsubsection{Independent Variables}


I have two sets of key explanatory variables, one for the resource dependence explanation and the other for my argument of the new decision context. A firm's dependence on institutional investors is measured by the percentage of the firm's shares held by institutional investors. Data on institutional ownership were obtained from Thomson Financial's institutional ownership database. To compare the influence of blockholding and smallholding institutions, I divide the overall institutional ownership into three parts, one by blockholders (those holding more than 5 percent of a firm's stock), another by intermediate holders (those holding between 1 and 5 percent), and finally one by smallholders (those holding less than 1 percent). This 5 percent threshold for blockholders has been widely used in other studies (e.g., Hambrick and Finkelstein 1995; Salancik and Pfeffer 1980; Tosi and Gomez-Mejia 1989). To compare the influence of pressure-resistant and pressure-sensitive institutions, I divide the overall institutional ownership into 5 different pieces, each by different types of institutions including banks, insurance companies, investment companies (i.e., mutual funds), investment advisors, and public pension funds. Among them, the first three — banks, insurance companies, and mutual funds—are often regarded as pressure-sensitive in the literature, while public pension funds are seen as pressureresistant. The remaining category, investment advisors, is not clearly defined as either in the literature, and so I leave it as an indeterminate category.

I construct another set of measures for agency-theory prescriptions to account for the changed decision context. First of all, the extent to which a firm's CEO is compensated with stock options is measured using the ratio of stock-option to total compensation. I also include total CEO compensation. Because Compustat's Execomp database began to report stock option values, calculated using the Black-Scholes-Merton method, in 1992, I explore the effects of compensation in separate models, with a one-year lag, for 1993-2005. Second, board 
independence is measured by the percentage of outside directors on the board. Outside directors are defined as any directors not employed by the firm. Information for this variable is taken from Standard \& Poor's Register of Corporations, Directors, and Executives. Finally, the presence of a CFO is measured as a binary variable, coded as one when a firm has a CFO. Information for these two variables is taken from Standard \& Poor's Register.

\subsubsection{Control Variables}

I include several control variables that have previously been shown to affect a firm's decision to downsize. Table 2.1 presents data sources for each variable along with descriptive statistics. Some variables included in the analyses vary annually, and others vary quarterly. They are lagged so that they reflect the state in the previous fiscal year or quarter.

First of all, I control for a given firm's performance prior to downsizing. For operating performance, I include return on assets (ROA). For stock-market performance, I include cumulative stock returns over three months (change in share price). Investment in new technology is measured using a firm's net expenditure in property, plant, and equipment (PPE) per employee. Debt burden is measured by debt-to-equity ratio. To account for the possibility that workforce downsizing follows other restructuring moves, I include the number of acquisitions and divestitures completed by the focal firm in the previous fiscal quarter. Corporate strategy also matters. Firms that pursue a focused strategy often shed jobs as they get rid of noncore businesses. To account for this, the degree of diversification is included, measured using the entropy index (Palepu 1985). Some firms engage in downsizing to avoid unwanted takeover attempts. To account for this, an indicator variable is included when a given firm was the target of an unwanted takeover bid in the previous quarter. Three binary variables for CEO functional 
Table 2.1: Data Sources and Descriptive Statistics

\begin{tabular}{|c|c|c|c|}
\hline & Data Source & Mean & S.D. \\
\hline CEO Options/Comp. & Execomp & 0.330 & 0.267 \\
\hline Board Independence & S\&P Registers & 75.646 & 13.409 \\
\hline Chief Financial Officer (CFO) & S\&P Registers & 0.618 & 0.486 \\
\hline Institutional Ownership (IO) & Thomson Fin. & 51.545 & 21.384 \\
\hline IO by Blockholders & Thomson Fin. & 10.602 & 11.725 \\
\hline IO by Intermediate Holders & Thomson Fin. & 21.653 & 11.225 \\
\hline IO by Smallholders & Thomson Fin. & 19.290 & 9.949 \\
\hline IO by Banks & Thomson Fin. & 11.614 & 7.111 \\
\hline IO by Insurance Companies & Thomson Fin. & 4.269 & 3.948 \\
\hline IO by Investment Companies & Thomson Fin. & 9.703 & 9.270 \\
\hline IO by Investment Advisors & Thomson Fin. & 21.905 & 12.501 \\
\hline IO by Public Pension Funds & Thomson Fin. & 2.490 & 2.043 \\
\hline CEO Compensation & Execomp & 8.153 & 1.022 \\
\hline Cumulative Stock Returns & CRSP & 0.037 & 0.189 \\
\hline Return on Assets (ROA) & Compustat & 0.907 & 2.185 \\
\hline Net Investment in Fixed Assets & Compustat & 3.957 & 1.346 \\
\hline Debt-to-Equity & Compustat & 0.536 & 0.480 \\
\hline Acquisitions & SDC Platinum & 0.019 & 0.142 \\
\hline Divestitures & SDC Platinum & 0.155 & 0.505 \\
\hline Diversification & SDC Platinum & 0.003 & 0.051 \\
\hline Hostile Takeover Bid & SDC Platinum & 0.615 & 0.535 \\
\hline CEO Background: Finance & Who's Who in Finance & 0.192 & 0.394 \\
\hline CEO Background: Production & Who's Who in Finance & 0.199 & 0.399 \\
\hline CEO Background: Operations & Who's Who in Finance & 0.258 & 0.438 \\
\hline Number of Employees & Compustat & 2.841 & 1.207 \\
\hline Total Assets & Compustat & 7.827 & 1.538 \\
\hline Within-Industry Downsizing Density & & 0.491 & 0.435 \\
\hline Industry Growth Rate & Compustat & 10.595 & 202.754 \\
\hline Union Coverage & Unionstat.com & 20.978 & 14.587 \\
\hline Quarterly Change in CPI & U.S. Dept. of Commerce & 0.831 & 0.555 \\
\hline Recessionary Period & Burea of Labor Statistics & 0.234 & 0.423 \\
\hline Annual Time-Trend & & 12.096 & 7.311 \\
\hline
\end{tabular}


backgrounds are also included: (1) finance, (2) engineering or production, and (3) operations. Firm size is measured as both the size of a given firm's total assets and the number of employees. Several important aspects of macroeconomic or institutional contexts are also considered. Density of downsizing is measured as the percentage of firms within the focal firm's industry, minus the focal firm, that announced downsizing plans in the previous year. Industry growth rate is measured as the percentage change in the aggregate sales for each 2-digit SIC industry the firm operates in. Aggregate sales were calculated using information for all companies in Compustat. Quarter-to-quarter changes in the Consumer Price Index (CPI) tap overall macro economic conditions. An indicator variable for recessionary periods (1990-1991 and 2000-2001) is included. An annual time-trend variable is included to capture the effect of unmeasured secular trends. Last but not least, a measure of unionization at the industry level is included (see Hirsch and Macpherson 2003).

\subsubsection{Missing Values and Multiple Imputation}

For some financial variables, missing values are of concern. The most severe case is the ROA variable; for about 15 percent of all quarterly intervals, this information is not available. For all the other variables, the rate of missing data is less than 5 percent. When data are missing for nonrandom reasons, list-wise deletion can yield biased estimates (Allison 2002). To address this problem, I estimated missing values for these variables using a multiple imputation program, Amelia II (King et al. 2001). Results are robust to the exclusion of organization-years for which there are missing data. 


\subsubsection{Modeling Procedure}

I analyze downsizing announcements between the first fiscal quarter of 1981 and the fourth fiscal quarter of 2006. For each announcement, I obtained information on the exact date of its occurrence. Hence, the metric for duration time is day, which is fine-grained enough to allow me to use continuous-time event history models rather than discrete-time models. Announcement spells are defined as the time intervals between announcements; in other words, the duration time is reset to zero every time an event occurs. Since firms in the sample typically made more than one downsizing announcement, the total number of announcement spells exceeds the number of firms. In most cases, the first spell is left-truncated. For these left-truncated spells (457 spells about 10 percent of the entire set), the beginning point was set to January 1st, 1980. Since this procedure can lead to biased estimates, I conducted a robustness check by estimating models without those spells whose beginning was set to January 1, 1980. This is the most common method for addressing the problem of left-truncation (Singer and Willett 2003). The results are qualitatively the same.

Covariates are updated on a quarterly basis. To do so, I split each announcement spell into quarterly intervals. Each quarterly interval starts at the date of quarterly earnings report and ends immediately prior to the next quarterly earnings report. Specifically, at each date of a firm's quarterly earnings announcement, I note whether the firm meets or beats the consensus analyst forecast and update information on explanatory and control variables. Next, I observe whether or not the firm makes a downsizing announcement. If no announcement occurs until the next quarterly earnings report, I update information on variables at that point and repeat the same process. If an announcement occurs within the quarterly interval, however, I record the duration time since the beginning of the given announcement spell and start another spell. 
I use a Cox regression model for estimation. One important advantage of Cox regression over other parametric models is that one does not have to choose some particular probability distribution to represent survival times. Without having much prior knowledge, any choice of the functional form for the baseline hazard function would be arbitrary. Instead, the Cox regression model lets the data determine the shape of the hazard function (Singer and Willett 2003). This is preferable for the present research. Like most social science research, the present research is chiefly concerned with the relationship between the outcome and covariates of theoretical interest and less concerned with the specific form of the duration dependency, which can be sensitive to the posited model (Box-Steffensmeier and Jones 2004, p. 47).

The repeatability of the event under study requires special treatment; there can be dependence among the multiple observations from the same unit, arising from unobserved heterogeneity (Allison 1995, p. 240). To address this issue, I use fixed-effects Cox regression, which lets announcement spells from a firm share the same baseline hazard function. Allison (Allison 1996, p. 220) suggests that, under conditions of moderate censoring, the fixed-effects estimator is more suitable for handling repeatable events than conventional single-event approaches. One shortfall of this approach is that it drops subjects with no events, that is, those with only a single right-censored spell as well as subjects with one uncensored spell and one censored spell, if the censored spell is shorter than the uncensored spell (Allison 2005, p. 116). An alternative approach, which does not exclude firms experiencing no event, is the conditional frailty model - the Cox model with the frailty term (Box-Steffensmeier and Jones 2004). This model is basically a random-effects model and thus has the same strengths and weaknesses. Like other random-effects models, it assumes no correlation between the random effect and covariates in the model. If this assumption holds, it is more efficient (i.e., the estimated standard errors are 
smaller) than a fixed-effects Cox model, but if not, the resulting estimates can be biased and inconsistent. Despite potential loss of data and efficiency, however, I draw primarily on the results of the fixed-effects Cox model, because it enables one to make a more stringent causal argument than the random-effects model, by accounting for all unobserved subject-specific characteristics that do not vary over time (Allison 2005, p. 112). Finally, tied event times are handled using the Efron method (Efron 1977).

\subsection{RESULTS}

Figure 1 plots the frequency of downsizing announcements by firms in my sample between 1981 and 2006. Firms still engage in workforce downsizing during economic downturns, but there are also a couple of new trends to be noted. First, workforce downsizing has generally become more frequent in the latter period. There were more downsizings during the recession in the early 2000s than during the recessions in the early 1980s and 1990s. Moreover, firms continued to downsize throughout the 1990s, despite an improving economy. Hence, there is a significant negative correlation between GDP growth and downsizing frequency $(-0.551 ; \mathrm{p}<0.05)$, but it becomes tenuous after the $1980 \mathrm{~s}(-0.203 ; \mathrm{p}>0.05)$. If only years in the $1990 \mathrm{~s}$ are considered, the correlation becomes close to zero $(0.086 ; \mathrm{p}>0.05)$.

The fixed-effects Cox models of downsizing announcements reported in Table 2.2 test both the resource-dependence hypotheses and the decision-context hypotheses. Models 1 through 6 cover the entire period from 1981 to 2006. Models 7 through 9 cover the sub-period between 


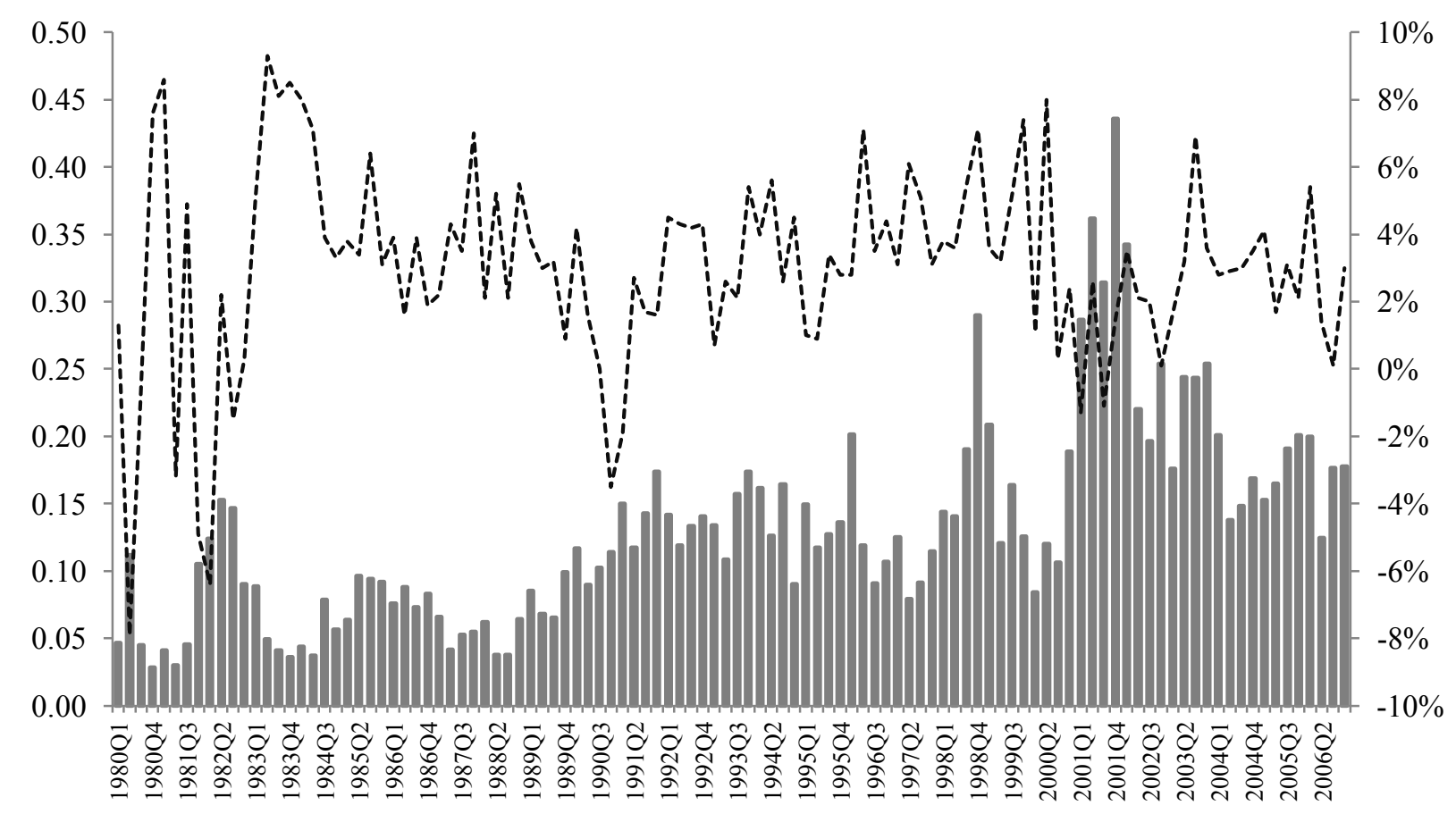

Frequency of Downsizing Announcements

GDP Percent Change

Figure 2.1: Downsizing Announcements

Note: Frequency is calculated as the number of downsizing announcements divided by the number of companies in the sample, each quarter; GDP percent change is based on 2005 dollars.

1993 and 2006, because executive compensation variables are only available, with a one-year lag, from 1993. Models 1 and 7 are baseline models with only control variables. Models 2 through 4 test the resource-dependence hypotheses with variables of institutional ownership. Models 5, 6, 8, and 9 test the decision-context hypotheses with variables of agency theory prescriptions.

Likelihood ratio tests show that, in all cases, adding these key explanatory variables significantly improves model fit over that of baseline models.

\subsubsection{Resource-Dependence Predictions}

The results in Table 2.2 support the resource-dependence hypotheses. In Model 2, the overall institutional ownership is negatively related to the hazard rate of downsizing announcements, 
Table 2.2: Continuous-Time Event-History Analysis of Downsizing Announcments (Cox Model with Stratification by Firm)

\begin{tabular}{|c|c|c|c|c|c|c|c|c|}
\hline & \multicolumn{8}{|c|}{$1981-2006$} \\
\hline & \multicolumn{2}{|c|}{ Model 1} & \multicolumn{2}{|c|}{ Model 2} & \multicolumn{2}{|c|}{ Model 3} & \multicolumn{2}{|c|}{ Model 4} \\
\hline & Coef. & S.E. & Coef. & S.E. & Coef. & S.E. & Coef. & S.E. \\
\hline \multicolumn{9}{|l|}{ Direct Power } \\
\hline Institutional Ownership & & & 0.002 & $(0.001)$ & & & & \\
\hline By Inst. Holding Less Than 1\% & & & & & $-0.038 * * *$ & $(0.003)$ & & \\
\hline By Insti. Holding b/w $1 \%$ and $5 \%$ & & & & & $0.008 * * *$ & $(0.002)$ & & \\
\hline By Insti. Holding More Than 5\% & & & & & $0.009 * * *$ & $(0.002)$ & & \\
\hline By Banks & & & & & & & $-0.029 * * *$ & $(0.003)$ \\
\hline By Insurance Companies & & & & & & & $-0.013 *$ & $(0.006)$ \\
\hline By Investment Companies & & & & & & & $0.013 * * *$ & $(0.002)$ \\
\hline By Investment Advisors & & & & & & & $0.005^{*}$ & $(0.002)$ \\
\hline By Public Pensions & & & & & & & $0.044 * * *$ & $(0.010)$ \\
\hline \multicolumn{9}{|l|}{ Indirect Power } \\
\hline \multicolumn{9}{|l|}{ Board Independence } \\
\hline \multicolumn{9}{|l|}{ Chief Financial Officer (CFO) } \\
\hline \multicolumn{9}{|l|}{ CEO Options/Comp. } \\
\hline \multicolumn{9}{|l|}{ Control Variables } \\
\hline Cumulative Stock Returns & $-1.011 * * *$ & $(0.083)$ & $-1.014 * * *$ & $(0.083)$ & $-1.024 * * *$ & $(0.082)$ & $-1.034 * * *$ & $(0.083)$ \\
\hline Return on Assets (ROA) & $-0.074 * * *$ & $(0.006)$ & $-0.074 * * *$ & $(0.006)$ & $-0.066^{* * *}$ & $(0.007)$ & $-0.073 * * *$ & $(0.006)$ \\
\hline Net Investment in Fixed Assets & $0.262 * * *$ & $(0.061)$ & $0.267 * * *$ & $(0.061)$ & $0.268 * * *$ & $(0.061)$ & $0.229 * * *$ & $(0.061)$ \\
\hline Debt-to-Equity & -0.064 & $(0.041)$ & -0.060 & $(0.041)$ & $-0.151 * * *$ & $(0.042)$ & -0.075 & $(0.041)$ \\
\hline Acquisitions & $0.384 * * *$ & $(0.083)$ & $0.384 * * *$ & $(0.083)$ & $0.416^{* * *}$ & $(0.083)$ & $0.392 * * *$ & $(0.083)$ \\
\hline Divestitures & $0.071 * *$ & $(0.022)$ & $0.071 * *$ & $(0.022)$ & $0.063 * *$ & $(0.022)$ & $0.069 * *$ & $(0.022)$ \\
\hline Number of Employees & $1.147 * * *$ & $(0.071)$ & $1.164 * * *$ & $(0.072)$ & $1.217 * * *$ & $(0.071)$ & $1.253 * * *$ & $(0.074)$ \\
\hline Total Assets & $0.261 * * *$ & $(0.055)$ & $0.237 * * *$ & $(0.058)$ & $0.292 * * *$ & $(0.057)$ & $0.143^{*}$ & $(0.060)$ \\
\hline Within-Industry Downsizing Density & $0.754 * * *$ & $(0.042)$ & $0.753 * * *$ & $(0.042)$ & $0.725 * * *$ & $(0.043)$ & $0.694 * * *$ & $(0.043)$ \\
\hline Industry Growth Rate & $-0.003^{*}$ & $(0.001)$ & $-0.003 *$ & $(0.001)$ & $-0.002 *$ & $(0.001)$ & $-0.002 *$ & $(0.001)$ \\
\hline Union Coverage & $-0.007 * *$ & $(0.002)$ & $-0.007 * *$ & $(0.002)$ & $-0.005 *$ & $(0.002)$ & -0.004 & $(0.002)$ \\
\hline Quarterly Change in CPI & $-0.188 * * *$ & $(0.028)$ & $-0.186^{* * *}$ & $(0.029)$ & $-0.185 * * *$ & $(0.028)$ & $-0.175 * * *$ & $(0.029)$ \\
\hline Recessionary Period & $0.245^{* * *}$ & $(0.036)$ & $0.249 * * *$ & $(0.036)$ & $0.254 * * *$ & $(0.036)$ & $0.277 * * *$ & $(0.036)$ \\
\hline Log Likelihood & \multicolumn{2}{|c|}{$-20,163.209$} & \multicolumn{2}{|c|}{$-20,162.332$} & \multicolumn{2}{|c|}{$-20,051.632$} & \multicolumn{2}{|c|}{$-20,088.022$} \\
\hline No. Quarterly Intervals & \multicolumn{2}{|c|}{46,823} & \multicolumn{2}{|c|}{46,823} & \multicolumn{2}{|c|}{46,823} & \multicolumn{2}{|c|}{46,823} \\
\hline No. Announcement Events & \multicolumn{2}{|c|}{5,787} & \multicolumn{2}{|c|}{5,787} & \multicolumn{2}{|c|}{5,787} & \multicolumn{2}{|c|}{5,787} \\
\hline No. Firms & \multicolumn{2}{|c|}{544} & \multicolumn{2}{|c|}{544} & \multicolumn{2}{|c|}{544} & \multicolumn{2}{|c|}{544} \\
\hline
\end{tabular}

$* \mathrm{p}<0.05 ; * * \mathrm{p}<0.01 ; * * * \mathrm{p}<0.001$ (two-tailed tests) 
Table 2.2 (Continued)

\begin{tabular}{|c|c|c|c|c|c|c|c|}
\hline \multicolumn{4}{|c|}{ 1981-2006 } & \multicolumn{4}{|c|}{$1993-2006$} \\
\hline & & & & & & & \\
\hline Coef. & S.E. & Coef. & S.E. & Coef. & S.E. & Coef. & S.E. \\
\hline
\end{tabular}

Direct Power

Institutional Ownership

By Inst. Holding Less Than 1\%

$\begin{array}{cc}-0.039 * * * & (0.003) \\ 0.006 * * & (0.002) \\ 0.008 * * * & (0.002)\end{array}$

$$
\begin{array}{cc}
-0.034 * * * & (0.005) \\
-0.002 & (0.003) \\
0.005 * & (0.002)
\end{array}
$$

By Insti. Holding More Than 5\% $0.008 * * * \quad(0.002)$

$-0.027 * * *(0.003)$

$-0.014 * \quad(0.006)$

$0.010 * * * \quad(0.002)$

$0.003 \quad(0.002)$

$0.040 * * * \quad(0.010)$

By Insurance Companies

By Investment Companies

By Investment Advisors

By Public Pensions

Indirect Power

Board Independence

$0.015 * * * \quad(0.002) \quad 0.012 * * * \quad(0.002)$

$0.228 * * * \quad(0.045)$

$0.223 * * * \quad(0.045)$

$0.017 * * * \quad(0.003)$

$0.130 \quad(0.071)$

$0.214 * \quad(0.092)$

Chief Financial Officer (CFO)

CEO Options/Comp.

Control Variables

Cumulative Stock Returns

Return on Assets (ROA)

Net Investment in Fixed Assets

Debt-to-Equity

Acquisitions

Divestitures

Number of Employees

Total Assets

Within-Industry Downsizing Density

Industry Growth Rate

Union Coverage

Quarterly Change in CPI

Recessionary Period

Log Likelihood

No. Quarterly Intervals

No. Announcement Events

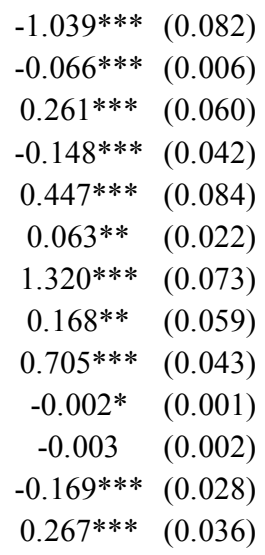

\begin{tabular}{cccc}
$-20,006.653$ & $-20,053.811$ & $-10,949.957$ & $-10,968.441$ \\
46,823 & 46,823 & 25,134 & 25,134 \\
5,787 & 5,787 & 3,749 & 3,749 \\
544 & 544 & 486 & 486 \\
\hline
\end{tabular}

No. Firms

$* \mathrm{p}<0.05 ;{ }^{* *} \mathrm{p}<0.01 ; * * * \mathrm{p}<0.001$ (two-tailed tests)
$0.016^{* * *} \quad(0.003)$

$$
\begin{array}{cc}
-0.023 * * * & (0.005) \\
-0.023 * * & (0.007) \\
-0.005 & (0.003) \\
0.003 & (0.002) \\
0.040 * & (0.016)
\end{array}
$$$$
0.142 * \quad(0.071)
$$$$
0.223 * \quad(0.092)
$$

486 
which is contrary to the resource dependence argument that firms heavily dependent on institutional investors are likely to downsize more frequently. This significant negative effect of institutional ownership, however, conceals considerable variation across different categories of institutional investors. The first source of variation is the size of their holdings. In Model 3, I replace overall institutional ownership with ownership by blockholding, intermediate holding, and smallholding institutions. As I have predicted, ownership by blockholding institutions significantly increases the hazard rate, whereas ownership by smallholding institutions significantly decreases it. A similar kind of variation is observed for between pressure-resistant and pressure-sensitive institutions. In Model 4, I replace overall institutional ownership with ownership by five different categories. As I predicted, ownership by pressure-resistant institutions, that is public pension funds, significantly increases the hazard rate, whereas ownership by pressure-sensitive institutions, especially banks, significantly decreases it. While the considerable amount of variation across different types of institutional investors and the positive effects of ownership by blockholding and pressure-resistant institutions support my predictions, the negative effects of smallholding and pressure-sensitive institutions requires some explanation. Do these negative effects suggest that such institutions do not want firms to downsize and lobby managers not to do so? It is possbile that they may not be enthusiastic about downsizing. Downsizing might improve a firm's profitability and thus its stock price in the intermediate and long run but could have an immediate, negative effect because downsizing often incurs significant restructuring costs, such as lump-sum severance payments to affected workers. But it is unlikely that smallholding or pressure-sensitive institutions would pressure firms not to downsize. What seems to happen instead is that they sell 
their holdings downsizing announcements, because rumors about possible downsizing announcements often widely circulate in the financial community.

To see if this is the case, I ran supplementary analyses of institutional ownership with relevant predictor variables, one of which was an indicator of downsizing announcements in the previous three-month period. Figure 2.2 plots the coefficients for the indicator variable from the analyses. As suspected, smallholders tend to leave firms just before downsizing announcements, while blockholders do not. Similarly, pressure-sensitive institutions, especially banks, also tend to leave firms just before downsizing announcements, while pressure-resistant institutions, public pension funds, do not. Since the models in Table 2 are basically fixed-effects models and thus

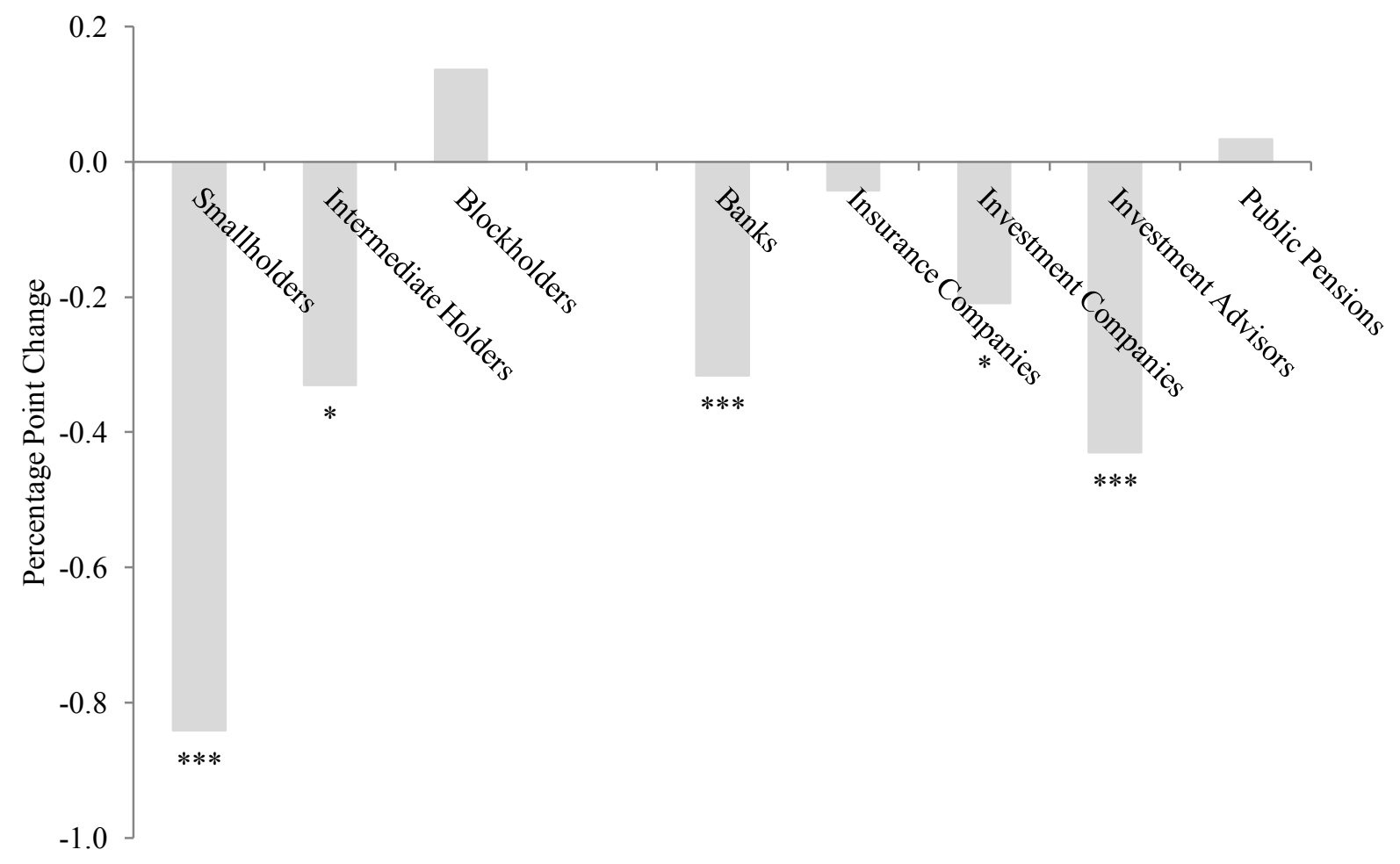

Figure 2.2: Changes in Institutional Ownership before Downsizing Announcements Note: Full models are presented in Appendix E. $* \mathrm{p}<0.05 ; * * \mathrm{p}<0.01 ; * * * \mathrm{p}<0.001$ (two-tailed tests) 
use only within-firm variation, a sudden drop in ownership by either smallholding or pressuresensitive institutions just before a downsizing announcement could generate a spurious negative association between their ownership and the hazard rate of downsizing announcements.

\subsubsection{Decision-Context Predictions}

The results in Table 2.2 also support my decision-context hypotheses. Firms that adopted or implemented the three agency theory prescriptions engage in workforce downsizing more frequently. First, when a significant portion of the CEO's compensation is equity-based through stock option grants, downsizing is more likely. The coefficient for the ratio of stock options to total CEO compensation is significantly positive in both Models 7 and 8 . Specifically, every one percent increase in stock options increases the hazard rate of downsizing by roughly 0.4 percent. Note also that the overall level of CEO compensation is negatively associated with the rate, suggesting that it is primarily the equity component of the compensation package that induces the $\mathrm{CEO}$ to adopt a downsizing plan. Second, the results in Models 5 and 6 also support Hypothesis 2-2 that outside directors significantly increase the risk of downsizing. The coefficient for the board-independence variable is 0.008 in Model 5 and 0.009 in Model 6, both significant at the 0.1 percent level. More concretely, given that the average board had about 12 directors during the study period, replacing one inside director with an outside director (i.e., about 8 percent increase in board independence) increases the hazard rate by about 7 percent. Finally, the results in Models 5 and 6 support Hypothesis 2-3 that firms with CFOs will engage in workforce downsizing more frequently. Having a CFO increases the hazard rate by 12 percent in Model 5 and by 13 percent in Model 6. 


\subsubsection{Control Variables}

A number of control variables show the expected effects. Both operating and stock-market performance decrease the rate of workforce downsizing. It also occurs more frequently after both acquisitions and divestitures. The degree of diversification also has a significant effect; diversified firms downsize less frequently. There is also evidence that firms that become targets of hostile takeover attempts are more likely to downsize. As for CEOs' functional backgrounds, those with a background in finance seem most willing to engage in downsizing. Both workforce size and the number of establishments increase the rate of downsizing, while asset size decreases it. As for environmental factors, the density of downsizing significantly increases the frequency of downsizing by the focal firm, probably reflecting some kind of contagion effect. Firms in declining industries engage in downsizing more frequently. Finally, union coverage has no significant effect on the hazard rate. Its coefficient has a positive sign but is not significant.

\subsubsection{Robustness Checks}

First, I did a robustness check without the left-truncated announcement spells. The results appear very similar to those in Table 2.2, except that the significance level for ownership by public pension funds and the presence of a CFO is reduced in Models 4 through 6. This appears to occur because, by dropping left-truncated spells, these models do not capture well the earlier part of the observation period. In fact, the model for the period after 1993 looks essentially the same. Second, because the fixed-effects estimator only includes subjects experiencing the event at least once, 99 firms with no announcement events are excluded, as well as 49 additional firms with one uncensored spell and one censored spell, because their censored spell is shorter than the uncensored one (Allison 2005, p. 115). In the end, 56 announcement spells are not used, which is 
about 1 percent of the entire announcement spells. To see if excluding these spells affects the results, I replicated the models in Table 2.2 using the Cox model with the frailty term. The results are very similar for most key explanatory variables.

\subsection{CONCLUSION}

Frustrated by the lackluster performance of leading U.S. companies in the 1970s, institutional fund managers have since sought to change the way firms are run. Throughout the 1980s, they challenged managers who ran large U.S. companies and pushed for the notion that the only legitimate goal of firms is shareholder-value maximization. By the 1990s, the shareholder-value paradigm was firmly in place. One clear indication is the prevalence of workforce downsizing. In the past, prominent U.S. companies had prided themselves on caring for their employees. Some (e.g., IBM) boasted of a no-layoff policy. Others in more cyclical industries (e.g., the Big Three automobile manufacturers) did use temporary layoffs during economic downturns but with the promise of recall. Shareholder primacy, however, leaves little room for such an implicit social contract between labor and business. Instead, leading U.S. companies now regularly downsize to maintain, restore, or boost stock price.

In the present paper, I provide a theoretical account of this transformation of workforce downsizing as a shareholder-value strategy, building on two prominent theories in organizational sociology — resource dependence theory and Fligstein's theory of conceptions of control, respectively. Building on resource dependence theory, I suggest that firms' growing dependence on equity-financing makes them vulnerable to pressure from institutional investors, and that such pressures lead firms to downsize more frequently in their attempt to enhance stock performance. However I further suggest that their direct pressure may be limited to the extent that they are 
vulnerable to pressure from management and their ownership is dispersed. The results of my analysis largely support my argument. Although overall institutional ownership decreases the rate of downsizing announcements, that negative effect is mostly due to ownership by smallholding institutions, which tend to leave just before downsizing announcements. In contrast, ownership by blockholding institutions significantly increases the rate of downsizing announcements. Similarly, ownership by institutions that are unlikely to challenge management because of their current or potential business ties to firms (particularly banks) is negatively related to the rate of downsizing announcements, because they also tend to divest before downsizing announcements, whereas ownership by public pension funds, which are least vulnerable to pressure from management, significantly increases the rate of downsizing announcements.

Second, further developing Fligstein's theory of conceptions of control, I suggest that the rise of the shareholder-value paradigm of the firm has reshaped the behavior of managers with respect to downsizing, by constructing a decision context in which firms and their executives are induced to jump on the downsizing bandwagon. For most of the twentieth century, managers had little incentive to pursue shareholder-value maximization. The diffusion of various agencytheory prescriptions has created a decision context in which managers view the maximization of shareholders' wealth as in their own interest. Thanks to executive stock option grants and other equity-based compensation practices, executives have a greater stake in increasing share price. Monitoring by independent directors means that executives face an increased risk of losing their jobs if they fail to satisfy shareholders and fund managers. The rise of CFOs as second-incommand to the CEO further infuses the shareholder-value orientation into the top management team. My results suggest that these agency-theory prescriptions presage the rise in downsizing by 
altering the context of managerial decision-making; managers have actively engaged in workforce downsizing more frequently, as they aim at maximum possible returns to their shareholders.

My research makes a strong case for the financialization of the American corporation and the ascendance of shareholder power, by demonstrating the influence of institutional investors and shareholder-value-oriented managers over leading U.S. firms' decision to downsize. Recently, a number of prominent scholars of industrial relations as well as sociologists have maintained that the growing pressure from financial markets and the rise of shareholder value have brought drastic changes to the employment policies of leading U.S. companies (Budros 1997; 2002; Cappelli 1999; Fligstein and Shin 2007; Hirsch and De Soucey 2006; Osterman 1999). With a corresponding power shift within corporations to executives responsible for finance, U.S. firms have placed a low priority on human resources relative to financial and shareholder considerations (Kochan forthcoming). As a result, firms downsize more readily than before, in order to raise the price of their stock immediately, even though it remains uncertain whether this strategy will improve their long-term viability. Although plausible, much more research is needed to specify how pressure from financial markets has induced firms to downsize. For instance, few studies directly examine the influence of institutional investors in the process, although many have suspected that they have played a crucial role (Batt and Appelbaum 2010; Useem 1996). My empirical findings demonstrate that the direct pressure from certain types of institutional investors has indeed resulted in more downsizing. My findings also demonstrate that the changed decision context, through the adoption of agency-theory prescriptions, has further contributed to the prevalence of downsizing, by promoting managers' acceptance of downsizing as an effective strategy to enhance shareholder value. 
Beyond the contribution to the literature on workforce downsizing, the present research has broader theoretical implications for the literature of organizational sociology. My findings about the role of institutional investors highlight the importance of agency and power in institutional change, which, as criticized by many, previous studies by institutionalists have often neglected (DiMaggio 1988; Mizruchi and Fein 1999; Perrow 1986). Of particular importance in this respect is to elaborate the role of external power groups in institutional change. Recent efforts at synthesizing institutional and power theories emphasize that many historical examples of institutional change reflect the interest of powerful external groups (Dobbin and Dowd 2000; Roy 1997). This insight is particularly relevant in understanding the behavior of large corporations under the "new financial capitalism" (Davis 2009). Previously, professional managers literally monopolized the authority to determine key strategic decisions (Berle and Means 1933), but this kind of managerialism has recently been challenged. Since the 1980s, power groups in financial markets have exerted significant influence over important corporate decisions whose implications extend beyond the corporate and financial sectors (Davis et al. 1994; Dobbin and Zorn 2005; Useem 1996). This research demonstrates the role of one such group, institutional investors, in reshaping employment policies of leading U.S., through their promotion of workforce downsizing.

But my findings about decision context also point to the social construction of change agents. In the case at hand, agency theory and external groups in financial markets promoting its prescriptions have succeeded in reconstructing the interest of corporate managers, bringing the interest of shareholders and share value back to the fore and suppressing interests of other stakeholders such as employees. The significant positive effects of the various shareholder-value prescriptions deserve some attention. Other studies have cast doubt on the effectiveness of these 
prescriptions in reducing agency costs and enhancing corporate performance. For instance, a number of studies of equity-based executive compensation practices have failed to find that they improve performance (Dalton et al. 2003). Studies of board independence have come to a similar conclusion (Bhagat and Black 1999). Both of these shareholder-value prescriptions, however, induce downsizing. Although managers initially resisted shareholder primacy, in the changed decision context resulting from corporate embrace of various agency theory prescriptions, they have become agents of shareholder value and have actively engaged in downsizing. 


\section{LABOR RESISTANCE, PUBLIC POLICY, AND CHANGING LAYOFF POLICIES}

Waves of downsizing have swept through corporate America since the 1980s, eroding whatever sense there had been of economic security for middle and working class Americans. This change reflects a fundamentally new conceptualization of employment relations on the part of employers and marks a radical departure from what Paul Osterman (1999) terms the "postwar institutional structure" of the labor market, in which employees of large American companies in primary business sectors have enjoyed a fairly high degree of job security and career stability. Not only did downsizing become more prevalent during this period, but its basic nature also changed. Previously, firms used to lay off employees in response to market demands but now cut jobs, often on a massive scale, even when times are good in order to boost financial performance. Moreover, whereas layoff previously meant temporary suspension of employment with an explicit or implicit agreement that laid-off employees would be called back when economic conditions improved, it now usually means permanent termination (Appelbaum and Batt 1994; Cappelli 1999; Osterman 1999).

Behind this transformation of layoff policies are changing inter-class power dynamics in the corporate governance of large U.S. firms. Broadly defined, corporate governance refers to mechanisms of allocating power and wealth to key stakeholders, most importantly managers, shareholders, and workers (Davis 2005; Roe 2003). Previous sociological studies suggest that the changed power relations between managers and shareholders led to the rise of permanent layoff as a strategy of maximizing shareholder value (Budros 1997; 2002; Fligstein and Shin 2007; Hirsch and De Soucey 2006; Lazonick and O'Sullivan 2000). These studies, however, do not provide a full picture of the changing inter-class power dynamics in the process. While 
focusing on the power relations between managers and shareholders, they largely overlook the resistance from workers and labor unions. Why did once-influential unions fail to prevent both the decline of temporary layoff and the rise of permanent layoff? This still requires explanation.

To address this issue, I attend to the role of public policy. I argue that the policy regime in the 1980s affected the balance of power between business and labor and thereby facilitated the shift from temporary to permanent layoff. I build on the institutional literature on public policy and institutional change (Campbell and Lindberg 1990; Dobbin and Dowd 1997; 2000; Fligstein 1990; 1996; Marquis and Huang 2009; Roy 1997) and extend the literature in two main ways. First, I explore the role of public policy in shaping the power of groups to resist institutional change. My analysis demonstrates that labor unions, despite their declining political influence, attempted not only to maintain temporary layoff with a promise of recall but also to discourage permanent layoff to boost profits; but the policy regime of the 1980s significantly undermined the power of unions to do both. Second, I explore the role of policy in shaping legitimation processes; in this case, the perceived legitimacy of permanent and temporary layoff. My analysis shows how the anti-union, pro-business stance of the Reagan Administration, by undermining industrial unionism that supported temporary layoff, accelerated its deinstitutionalization while strengthening the legitimacy of permanent layoff. As a result, labor unions lost a critical battle in the 1980s and, although they regained some of their influence afterwards, did not fully recover from the loss.

\subsection{PUBLIC POLICY AND INSTITUTIONAL CHANGE}

There has been a long-standing interest among organizational sociologists, particularly those with a neoinstitutional perspective, in the role of public policy in institutional stability and 
change. In their seminal paper on institutionalization, Meyer and Rowan (1977, p. 347-8) posit that, as the centralized state expands its dominance over diverse domains of social life, organizations adopt practices institutionalized by the state. DiMaggio and Powell (1983, p. 150) also list government mandates as one source of coercive isomorphism, one of the three mechanisms of institutional diffusion (see also Tolbert and Zucker 1983).

Subsequent studies build on these initial insights and present a sophisticated account of the role of public policy in institutional change. In particular, a body of studies on modern personnel practices in the United States suggests that public policy plays a more subtle role than simply dictating specific actions (Baron, Dobbin, and Jennings 1986; Dobbin and Sutton 1998; Dobbin et al. 1993; Edelman 1990; 1992; Sutton and Dobbin 1996; Sutton et al. 1994). New policies often outlaw preexisting practices without providing clear mandates, leaving organizations themselves to formulate proper responses. Hence, the effect of public policy is not only direct but also indirect, a matter of constituting a new institutional environment to which organizations adapt.

Organizational sociologists who study the behavior of firms build on these further insights and explore how public policy shapes business strategies. Here again, its role is an indirect one through the manipulation of the institutional environment in which important corporate decisions are made. The modern state establishes and enforces rules for economic exchanges, which in turn determine the "institutional basis of power relations" among key economic actors (Campbell and Lindberg 1990, p. 642). By affecting the distribution of economic resources and power among key stakeholders of firms, such rules crucially defines "who has claims on the profits of firm" (Fligstein 1996, p. 658). Therefore, major shifts in public policy reshape the power relations among key stakeholders and affect their ability to promote 
and enforce their preferred business strategies, often leading to significant changes in dominant business strategies (Davis, Diekmann, and Tinsley 1994; Davis and Thompson 1994; Dobbin and Dowd 1997; 2000; Fligstein 1990; Roy 1997; Stearns and Allan 1996).

Previous studies have demonstrated this indirect effect of public policy, through its impact on power dynamics among key stakeholders, on business strategies. For example, Fligstein $(1985 ; 1987 ; 1990)$ shows that when the Celler-Kefauver Act of 1950 banned horizontal mergers (i.e., mergers between firms in the same industry), it stimulated intra-firm power struggles among managerial groups who promoted different solutions; ultimately, finance managers prevailed in their push for conglomerate mergers. The Reagan-era antitrust policy, however, again permitted horizontal mergers and provoked another round of power struggles, this time, between executives of conglomerate firms and corporate raiders targeting such firms (Davis, Diekmann, and Tinsley 1994; Stearns and Allan 1996). In response to the threat of hostile takeovers, large U.S. firms pursued the strategy of focusing on their core businesses and within-industry mergers, rather than conglomerate mergers and diversification.

In another example, Dobbin and Dowd (2000) demonstrate that the shift in government's antitrust policy in the late 19th century intensified inter-industry power struggles between railroad firms and financiers, who pushed for different models of managing competition. When antitrust laws banned cartels, large railroads moved to adopt predatory tactics of destroying competitors through a rate war. But financiers, with stock in many firms that might become prey, opposed predation, by threatening to cut capital flows to predators, and instead championed amicable mergers.

In this paper, I attempt to advance the literature on how public policy shapes business models in two main ways. First, I explore how public policy affects the ability of actors and 
groups to resist, as well as to promote, institutional change. Although many previous studies posit that policy shifts lead to institutional change by redefining power relations among interest groups, they rarely examine how a new policy actually affects the power of competing groups to promote or resist change. Instead, they mostly rely on proxy measures of intra- or interorganizational power struggle. ${ }^{4}$ More important, even studies that examine power struggle more directly tend to focus on how a new policy empowers groups who promote institutional change but rarely examine how the policy undermines the power of groups who may resist the change. As the literature on social movements suggests, mobilization of change agents often arouses counter-mobilization of groups who thrived under the status quo (Ingram and Rao 2004; Meyer and Staggenborg 1996; Vogus and Davis 2005). If the latter groups are powerful enough, drastic institutional change is unlikely (Ahmadjian and Robbins 2005). In such cases, a new policy may also contribute to institutional change by limiting the ability of such groups to resist it.

The second way in which I hope to advance the literature is by examining how policy shifts affect both the institutionalization and the deinstitutionalization of practices that are promoted by competing groups. Scott (1995) identifies three sources of institutionalizationregulative, normative, and cognitive-cultural. Obviously, public policy is an important source of regulative legitimacy. On the one hand, endorsement by the government legitimizes a given organizational practice (Baum and Oliver 1991; 1992; Ruef and Scott 1998; Russo 2001). On the other hand, competition or incongruence with the existing public-policy regime delegitimizes a given organizational form (Ingram and Simons 2000; Simons and Ingram 2003). In addition to this obvious effect of public policy, however, I suggest that a new policy can reinforce or undermine the other sources of institutionalization. Both organizational ecologists and

\footnotetext{
${ }^{4}$ For instance, Fligstein (1990) suggests that in each historical period a different managerial group prevailed and runs separate models for each period. This way, his analysis captures the effect of shifts in power but cannot show how the shifts occurred.
} 
institutionalists have argued that increases in the density of a given organizational form or practice increases its cognitive-cultural legitimacy and thereby facilitates its diffusion across organizations (DiMaggio and Powell 1983; Hannan and Freeman 1989). I suggest that this density-dependent legitimation process may itself be dependent on public policy regimes. When a new policy prioritizes the claims of one group over those of others, the prevalence of a practice championed by the privileged group will further legitimize the practice, while dampening a similar density-dependent legitimation process for practices backed by other groups. In doing so, policy shifts can accelerate both the institutionalization of practices promoted by newly empowered groups and the deinstitutionalization of practices supported by groups negatively affected by policy shifts. In the following, I will argue that these two public-policy-driven mechanisms of institutionalization were at work in the transformation of layoff policies of many large U.S. companies.

\subsection{THE TRANSITION FROM TEMPORARY TO PERMANENT LAYOFF}

During the 1980s and 1990s, postwar labor-market institutions went through a tremendous change (Osterman 1999), prominent indications of which were the prevalence of layoffs and a shift in their nature from temporary suspension of employment to permanent termination. Underlying this shift was the decline of industrial unionism, which was championed by labor unions, and the rise of the shareholder-value model of the firm, which was promoted by new power groups in the financial market. Under industrial unionism, unions and employers had set the rules governing various aspects of employment relations, including wages, benefits, working hours, job descriptions, and terms of layoff (Kochan, Katz, and McKersie 1994). Under the 
shareholder-value model, employers dismantled those rules and revised their employment practices in the interests of maximizing stock price.

\subsubsection{Industrial Unionism and Temporary Layoff}

The U.S. labor market is often said to be more market-oriented than its Western European and Japanese counterparts (Dore 1973; Hall and Soskice 2001; Swenson 2002). While this is generally the case, there still were considerable variation throughout American history in the extent to which market principles govern employment relations (Kochan et al. 1994). During the New Deal years, firms and unions, assisted by government intervention, developed a set of rules and norms by which they attempted to mitigate the harms to workers caused by excessive market competition (Baron, Dobbin, and Jennings 1986; Jacoby 1985). Paul Osterman (1999, p. 21) argues that these rules and norms induced firms to ensure employees a high degree of job security in return for reciprocal commitment from employees to stay with the firm and invest in firm-specific skills.

Labor unions, especially those in key industries such as automobile and steel, played a crucial part in establishing the postwar institutional structure. Many prominent elements of the system- e.g., seniority-based wage increases and closed and relatively stable internal career structures - emerged through bargains between major industrial unions and leading firms within the given industry. In particular, the agreement negotiated between General Motors and United Auto Workers (UAW) in 1948 became the model that was followed in other industries (Katz 1985). The resulting model of employment relations also significantly shaped employment practices in non-unionized sectors (Kochan et al. 1994). To deflect demand for unionization, employers paid wages and benefits that came close to union advances and adopted many of the 
internal career structures prevalent within unionized firms (Leicht 1989). Some non-union employers went even further; the no-layoff policies of IBM and of Digital Equipment are wellknown examples.

Temporary layoff followed by recall was one of the key elements of industrial unionism. Through this practice, firms could adjust the level of their workforce in response to declines in aggregate demand, while workers remained attached to their original employer. According to one estimate, at least 75 percent of the workers laid off in the manufacturing sector were subsequently rehired by their original employer during the 1970s (Feldstein 1976, p. 940). By the mid-1970s, temporary layoffs were so widespread that Martin Feldstein, a Harvard economics professor who served as chief economic advisor to President Ronald Reagan, proclaimed that "the overwhelming importance of temporary layoffs requires a revision of the basic conceptual framework within which layoffs and unemployment are now discussed" (Feldstein 1976, p. 955).

While it was still management who decided when to make layoffs, unions had considerable control over the process. Collective bargaining agreements often included rules about who would get laid off and how their work would be re-allocated. Unions generally preferred temporary layoff to alternative forms of workforce adjustment (e.g., reduced hours) for two main reasons (Freeman and Medoff 1984, p. 115-16). First, the burden of layoff fell more on junior workers, who had less influence in union decisions, than on senior workers, who were protected by seniority rules and thus often active union members. Second, the unemployment insurance system tended to reward layoff-intensive adjustment practices, because the employer's unemployment tax rate was capped; above a certain layoff rate, further layoff did not increase the employer's tax rate. In the 1960s and the 1970s, studies by labor economists show, firms in highly unionized sectors were more likely than those in non-unionized sectors to respond to 
declines in aggregate demand by temporarily laying off workers (Freeman and Medoff 1984; Medoff 1979; Montgomery 1991).

\subsubsection{Shareholder Value and Permanent Layoff}

The industrial unionism that guided employment practices in many large U.S. corporations began to collapse in the 1980s (Appelbaum and Batt 1994; Cappelli 1999; Kochan et al. 1994;

Osterman 1999). Foreign competition and deep recessions in the late 1970s and the early 1980s intensified firms' search for alternative models of workplace governance that would contain costs and enhance competitiveness (Barley and Gideon 1992). The anti-union, pro-business stance of the Reagan Administration and the steady decline of labor unions helped precipitate the demise of industrial unionism (Clawson and Clawson 1999).

Another significant cause of the collapse came from the financial sector - the rise of shareholder value. Osterman (1999, p. 30-31) suggests that the postwar institutional structure was possible partly because of the weak influence of shareholders during the postwar period. Formally, American corporate law gave shareholders primacy in the governance of the firm. In reality, however, as Berle and Means noted as early as 1933, professional managers, because of dispersed ownership, enjoyed a great deal of autonomy. Their relative autonomy allowed managers to make concessions to labor unions in workplace issues. To be sure, they did not so purely out of some kind of social consciousness. In fact, U.S. managers remained hostile to the industrial union model (Kochan et al. 1994). Resistance toward unions had been historically embedded in their belief system of U.S. managers (Bendix 1956). But while such anti-union sentiment persisted among managers, they nonetheless came to see unions as inevitable, and they 
pragmatically accommodated to collective bargaining in order to avoid the high costs of dislodging established unions (Kochan et al. 1994, p. 14).

This corporate governance system, characterized by "strong managers and weak owners" (Roe 1994) has gone through a significant change since the 1980s. Hostile takeovers in the 1980s and the growth of institutional ownership undermined the norm of managerial control (Davis et al. 1994; Davis and Thompson 1994; Gourevitch and Shinn 2005; Useem 1996). Assertive shareholders sought to regain control over key governance issues, such as the choice of chief executives and directors (Khurana 2002; Useem 1996). These new developments sent a strong message that firms must maximize shareholder value in order not to be victimized by the flux of the financial market (Dobbin and Zorn 2005; Fligstein and Markowitz 1993; Zajac and Westphal 2004). As managers sought to enhance profitability and thus stock price, less room was left for making concessions to labor unions. Instead, managers became more aggressive in demanding concessions from unions and cutting labor costs. Prior research suggests that the shareholdervalue orientation is closely related to the prevalence of massive layoff and the change in its nature (Budros 1997; 2002; Fligstein and Shin 2007; Lazonick and O'Sullivan 2000). While most layoffs in the past were temporary and often followed by recall, recent ones are more or less equivalent to permanent termination (Cappelli 1999; Osterman 1999).

\subsection{THE ROLE OF PUBLIC POLICY IN THE SHIFT OF LAYOFF POLICIES}

What role did public policy play in the shift of layoff policies? Of course, no policy specified which form of layoff firms should rely on when they had to adjust their workforce. But building on my discussion above regarding the role public policy in institutional change, I suggest that the policy stance of the government in the 1980s facilitated the shift, by weakening both the power 
of unions to resist the shift to permanent layoff and the cultural-cognitive legitimacy of temporary layoff. Labor unions tried to discourage permanent layoff and, when some kind of workforce adjustment was unavoidable, turned to temporary layoff, but their ability to do both was severely constrained by the anti-union, pro-business stance of the Reagan Administration. At the same time, many of the harsh actions taken by the same administration towards unions undermined the industrial unionism on which the cognitive-cultural legitimacy of temporary layoff was critically dependent, thereby facilitating the deinstitutionalization of temporary layoff as well as the institutionalization of permanent layoff. I first sketch hypotheses about the role of union resistance and cognitive-cultural legitimacy of both temporary and permanent layoff in the shift to the latter form of layoff. And then I discuss how the hypothesized effects of these two factors are contingent on the policy stance of the government.

\subsubsection{Resistance from Labor Unions}

Obviously, labor unions actively resisted the shift in the dominant model of employment relations. I suggest that union resistance came in two forms. First, they strove to sustain their preferred method of workforce adjustment - temporary layoff. While there is considerable evidence that they succeeded in the 1960s and 1970s, in that firms in highly unionized sectors were more likely to make temporary layoffs (Freeman and Medoff 1984; Medoff 1979; Montgomery 1991), it remains unclear whether labor unions exerted similar influence in the significantly changed economic and political environments since the 1980s. There is some indication that labor unions were able to maintain the use of temporary layoff, at least within their strongholds. During the 1987 Ford-UAW contract negotiations, for example, the union accepted lower wage increases and less rigid work rules than under the prior contract, in return 
for landmark job-security protections for its members, which, nevertheless, permitted temporary layoffs in case production had to be cut back because of a drop in sales (Holusha 1987). Given this strong preference of unions for temporary layoff, I expect that the use of temporary layoff is more likely within highly unionized sectors.

Hypothesis 1-1: Union density at the industry level is positively associated with the rate of temporary layoff.

At the same time, labor unions resisted the alternative form of workforce reductionpermanent layoff. Although the steady decline of union membership and union strike activities throughout the 1980s should have limited their ability to prevent permanent layoffs, unions did fight back fiercely. For instance, after AT\&T's announcement of 24,000 job cuts in August of 1985, the Communications Workers of America warned that the cutbacks could create "insurmountable obstacles" for AT\&T in negotiating a new contract with the union (Stevenson 1985). When this kind of warning was not well heeded by management, unions could resort to a more disruptive tactics, mostly importantly calling for a strike. Although such tactics might not prevent permanent layoff indefinitely, they might still discourage firms from considering it for the time being.

Hypothesis 1-2: Union strike activities will decrease the rate of permanent layoff.

\subsubsection{Cognitive-Cultural Legitimacy of Temporary versus Permanent Layoff}

Another factor that could affect the shift of layoff policies was the cognitive-cultural legitimacy of temporary layoff versus that of permanent layoff. Both institutionalists and organizational ecologists posit that organizations take the density of a given practice as an indicator of its cultural-cognitive legitimacy within the field (DiMaggio and Powell 1983; Hannan and Freeman 
1989). Studies have shown that as more organizations adopt the practice, it further induces other organizations to follow suit (Hannan and Carroll 1992; Hannan et al. 1995; Haveman 1993; Haveman and Rao 1997; Sine, Haveman, and Tolbert 2005; Tolbert and Zucker 1983). A similar pattern is observed in the case of permanent layoff. It was rare among prominent U.S. companies until the 1980s but soon became "business-as-usual" as more firms downsized (Budros 1999). While this growing prevalence of permanent layoff should help institutionalize this type of layoff, this might not immediately result in the deinstitutionalization of temporary layoff. In sectors with strong union presence, such as the automobile industry, a considerable number of firms continued to rely on temporary layoff as a means to adjust workforce throughout the 1980s. Although the number of such firms declined steadily, their continued use of temporary layoff should induce other firms in the same sector at least to consider relying on it rather than turning to permanent layoff. Hence:

Hypothesis2-1: The density of temporary layoffs will increase the rate of temporary layoff, and the density of permanent layoff will increase the rate of permanent layoff. At the same time, the density of one type of layoff may discourage firms from turning to the other type. Studies on inter-form competition show that the prevalence of one organizational form or practice can undermine the cognitive-cultural legitimacy of an alternative one (Barnett and Woywode 2004; Ruef 2000; 2004). As more organizations abandon a given practice and adopt an alternative practice, others will jump ship (Greve 1995). Hence, in the case of temporary layoff, firms are more likely to turn away from it when many firms in the same sector turn increasingly to permanent layoff. In this case, inter-form competition contributes to institutional change by facilitating the deinstitutionalization of a previously prevalent practice. In contrast, firms are less willing to rely on permanent layoff and stick to temporary layoff when 
most firms in the same sector do. In this case, inter-form competition delays institutional change by slowing down the institutionalization of a new practice.

Hypothesis2-2: The density of temporary layoffs will decrease the rate of permanent layoff, and the density of permanent layoff will decrease the rate of temporary layoff.

\subsubsection{The Role of Public Policy}

My third and most important set of hypotheses concerns how public policy affects the power of labor unions and the density-dependent process of legitimation. Previous studies suggest that a significant shift in public policy can change the balance of power among interest groups within and around the firm, and thereby affect the institutional standing of the practices promoted by each group (Davis et al. 1994; Dobbin and Dowd 2000; Fligstein 1990; Roy 1997; Stearns and Allan 1996). I focus here on the policy regime in the 1980s, a time of many significant policy changes regarding the role of unions.

Particularly relevant to the present study is the anti-union stance of the Reagan Administration. Deeply influenced by free market ideology, Reagan officials were wary of measures that would restrict management's flexibility, including the ability to fire employees. This stance significantly undermined the ability of labor unions to challenge management. Government policies, of course, had always affected labor unions' ability to challenge management, but their influence intensified and became more adverse under the Reagan Administration. Early in industrialization, the government mostly attempted to repress strike activities, but, after the New Deal, it turned to the more preventive approach of encouraging collective bargaining between management and organized labor and thus significantly enhanced unions' bargaining power vis-à-vis management throughout the postwar period (Kaufman 1982; 
McCammon 1993; Snyder 1975). The Reagan Administration, however, turned the tables again and took a more repressive approach, as was seen in its unrelenting response to the air traffic controllers' strike in 1981 that resulted in the firing of 11,000 striking air traffic controllers. As a result of this change in the political environment, the effect of strike activities on the economic standing of workers has been significantly reduced since the 1980s (Rosenfeld 2006; Wallace, Leicht, and Raffalovich 1999).

The Reagan Administration's anti-union stance also severely undermined the ability of labor unions to organize workers. Emboldened by the Administration's pro-business stance, management adopted aggressive union-defying tactics such as illegal discharges and other employment reprisals against union activities (Cooke and Meyer 1990; Goldfield 1987; Meyer and Cooke 1993). In many cases, however, decisions and rulings by courts, National Labor Relations Board (NLRB), and other federal and state agencies were made in favor of management (Goldfield 1987). As a consequence of various union-defying tactics and favorable court and administrative rulings, the frequency of union certification elections and the percentage of union victories fell sharply (Farber and Western 2002; Tope and Jacobs 2009). Particularly vulnerable to this changed political environment were unions in key manufacturing sectors, such as automobile and steel, that were accustomed to business-labor cooperation under industrial unionism (Martin and Dixon 2010).

I expect that the actions taken by the Reagan Administration to weaken the power of labor unions both to maintain temporary layoffs and to prevent permanent layoffs. Particularly relevant to the case of layoff policies is the struggle over the Worker Adjustment and Retraining Notification Act (WARN), which required employers to notify employees at least 60 days in advance of permanent layoffs or plant closings. The legislation was originally a provision of a 
comprehensive trade bill as a concession made to unions for their support for the bill. When the bill passed both the Congress and the Senate in 1988, however, President Reagan vetoed the entire bill because of the plant-closing provision. The provision passed as a separate law later the same year and avoided the President's veto, but only after the requirement of 60 days' notice was significantly watered down. ${ }^{5}$ By first vetoing and then watering down WARN, the Administration successfully defeated unions' attempt to gain some nominal control over layoff policies. This kind of incident suggests that the 1980s under the Reagan Administration (and to a lesser degree under the Bush Administration) was a particularly hostile political environment for unions. Although the stance of subsequent administrations was hardly pro-labor, the Reagan Administration's stance was by far most anti-union.

Hypothesis 3-1: The positive effect of union density on the rate of temporary layoff will be less in the 1980 s than in the later period.

Hypothesis 3-2: The negative effect of union strike activity on the rate of permanent layoff will be less in the 1980 s than in the later period.

I further expect the anti-union stance of the Reagan Administration to impair the cognitive-cultural legitimacy of temporary layoff, which was supported by unions, while strengthening that of permanent layoff, which was preferred by managers. Although the government did not openly advocate permanent layoff over temporary layoff, it did so indirectly. Elected with a promise to reduce the size of government, the Reagan Administration vehemently pursued public sector downsizing. According to one estimate, during the first three years of the Reagan administration, more than 12,000 of 1.4 million white-collar civil servants were fired

\footnotetext{
${ }^{5}$ The revised bill affected only companies that employ at least 100 full-time workers at one site and required notice only if 500 workers or one-third of a plant's work force, whichever was lower, were affected by a layoff order. A company was also exempt from the requirement if the closing or layoff was caused by "not reasonably foreseeable circumstances" like a flood or drought. Finally, the requirement also did not apply if sending out a notice would harm the company's ability to raise capital or attract new business or if the company's workers were on strike.
} 
(Causey 1985). The recurring rhetoric of a smaller and more efficient government resonated perfectly with the popular business rhetoric of "lean and mean" firms, which was frequently heard when firms justified their layoff and plant-closing decisions (Budros 2002). I expect this political environment privileging firms' right to dismiss workers to alter the density-dependent process of legitimation between temporary and permanent layoff, in favor of the latter. Hence, the positive density effect on the rate of the same type of layoff will become weaker in the case of temporary layoff but stronger in the case of permanent layoff. At the same time, the negative density effect on the rate of the other type of layoff will be weaker in the case of temporary layoff but stronger in the case of permanent layoff. Hence:

Hypothesis 3-3: The positive effect of temporary-layoff density on the rate of temporary layoff will be less in the 1980s than in the later period, while the positive effect of permanentlayoff density on the rate of permanent layoff will be greater in the 1980s than in the later period.

Hypothesis 3-4: The negative effect of temporary-layoff density on the rate of permanent layoff will be less in the 1980s than in the later period, while the negative effect of permanentlayoff density on the rate of temporary layoff will be greater in the 1980s than in the later period.

\subsection{DATA AND METHOD}

I present event-history models of temporary versus permanent layoff announcements, which runs two separate event history models for each form of layoff. This method is suited to testing whether the power of labor unions and density dynamics work differently for the two types of layoff. The analysis covers the period from 1984 to 2006. Due to data issues-most labor-union- 
related variables are available from only 1984 on - the analysis does not cover the first term of the Reagan Administration, but even with this limitation, my models capture significant effects of policy shifts during the period.

\subsubsection{Sample}

The original sample included 789 large U.S. companies that were traded between 1965 and 2006. The primary sampling frame is Fortune's list of America's largest firms. I and my collaborators in data collection stratified the sample by industry, selecting a roughly equal number of firms from 23 industries. ${ }^{6}$ Most industries (16 out of 23) were sampled exclusively from the Fortune Industrial 500, and the remainder from specialized Fortune lists. For entertainment and health care, we used Dun \& Bradstreet's Million Dollar Directory for years before 1983, at which point Fortune began to cover these industries. Another important aspect of our sample is that, unlike most longitudinal studies of large firms that use samples drawn at the beginning, we sampled firms evenly across the entire observation period. This ensures that our sample is not biased toward successful firms in later years and includes firms in growing as well as declining industries. For the present study, I use data on 681 firms that were listed as companies between 1984and 2006. It covers a period early enough to observe the transformation of layoff policies, because previous studies suggest that it happened after the early 1980s (Cappelli 1999; Kochan et al. 1994; Osterman 1999).

\subsubsection{Dependent Variable: Layoff Announcements}

I have collected information on the history of layoff announcements for the firms in my sample since 1980. The data are obtained through extensive archival search. The primary source is the

\footnotetext{
${ }^{6}$ See Footnote 1.
} 
Lexis/Nexis electronic database. The database catalogues most major newspapers, such as The Wall Street Journal and The New York Times, and several newswire services. Rather than relying on one or two major newspapers - a tactic that most previous studies adopted-I use all possible sources, including local newspapers. Cases that referred to previously announced layoffs were dropped. Ultimately, 5,717 layoff announcements were identified. I classify them into announcements of temporary layoff and those of permanent layoffs. An announced layoff was regarded as temporary when the firm described it as such (often by implying that) and revealed its duration. Firms sometimes did not reveal the duration of announced layoffs but instead said that they would last for an "indefinite" period. While this kind of layoff are in between temporary and permanent ones, I still regard it as a temporary one, because, when announcing an indefinite layoff, firms typically implied that the laid off workers would be recalled later. Finally, involuntary furlough, a practice that is common in industries such as the airline industry, is also regarded as temporary layoff. In total, 496 announcements are classified as temporary layoff announcements. The rest are considered as permanent.

\subsubsection{Independent Variables}

I use two measures of the influence of labor unions. The first measure is union membership at the industry level. Although a firm-level measure would be preferable (there are few reliable sources of firm-level union membership), the industry-level measure should capture the influence of unions over employment practices of firms within a given sector, because, as most historical accounts suggest, powerful industrial unions helped establish standards of employment practices within their respective industry, which even non-unionized employers could not simply ignore (Katz 1985; Kochan et al. 1994). The data on annual, industry-level union membership 
are provided by Hirsch and Macpherson (Hirsch and Macpherson 2003), via their website (http://www.unionstats.com). Their estimates are based on the Current Population Survey (CPS), using Bureau of Labor Statistics (BLS) methods. Because many firms have operations in more than one industry, I calculate a weighted average of union membership at industries in which a firm has operations. The weight for an industry is the portion of the firm's sales from that industry. This information is from Compustat's segment database. The second measure of the influence of unions is the incidence of union strike activities. I construct an indicator variable of whether there was an incidence of work stoppage involving 1,000 or more workers at the firms in my sample over the 12-month period. The data on work stoppage are from the Federal Mediation Conciliation Service (FMCS) and the BLS. The density of temporary (permanent) layoffs is measured as the percentage of firms within the focal firm's industry, not including the focal firm, that announced temporary (permanent) layoffs in the previous 12-month period. Finally, to capture the effect of the government's anti-labor stance in the 1980s, I construct an indicator variable for the period. The effects of the policy regime on both the influence of labor unions and layoff density are captured by interaction terms of these variables with the period indicator.

\subsubsection{Control Variables}

I also control for a wide range of firm-level as well as industry- or economy-wise factors that have previously been shown to affect a firm's decision to conduct a workforce reduction. Definitions and data sources for each variable are listed in Table 3.1. Some variables included in the analyses vary annually, and others vary quarterly. These control variables as well as the key explanatory variables are lagged so that they reflect the state in the previous fiscal year or quarter. 
First, I include measures of pressure from financial markets and of a given firm's shareholder-value orientation. Previous studies suggest that these factors are positively related to the rate of permanent layoff (Budros 1997; 2002). For pressure from financial markets, I include hostile takeover bids for a given firm and ownership by blockholding institutional investors (the percentage of a firm's stock owned by institutions holding 5 percent of more of its stock). For a firm's shareholder-value orientation, I control for the percentage of outside (i.e., non-employee) directors on the board, who are more independent of management than inside directors, and the presence of a chief financial officer (CFO), who often leads a firm's efforts at restructuring. In addition to those measures of a firm's shareholder-value orientation, other firm-level and environment-level factors are included. To begin with firm-level factors, a given firm's prior performance should be an important factor behind its decision for both temporary and permanent layoff. Return on assets (ROA) is a widely used measure of a firm's operating performance, and cumulative stock returns (the change in share price over the previous three months) measures the firm's stock performance. Another potentially important measure of performance is whether a firm meets the consensus (i.e., average) forecast of securities analysts covering the firm. I include a binary variable, coded as one if a firm's reported quarterly earnings per share is less than the consensus forecast. A firm's debt burden is measured by debt-to-equity ratio. To account for the possibility that workforce downsizing follows other restructuring moves, I include the number of acquisitions and divestitures completed by the focal firm in the previous fiscal quarter. The degree of diversification is measured using the entropy index of diversification (Jacquemin and Berry 1979; Palepu 1985). A firm's workforce size is the total number of employees, both domestic and foreign. Investment in new technology is measured using a firm's net expenditure in property, plant, and equipment (PPE) per employee. A firm's 


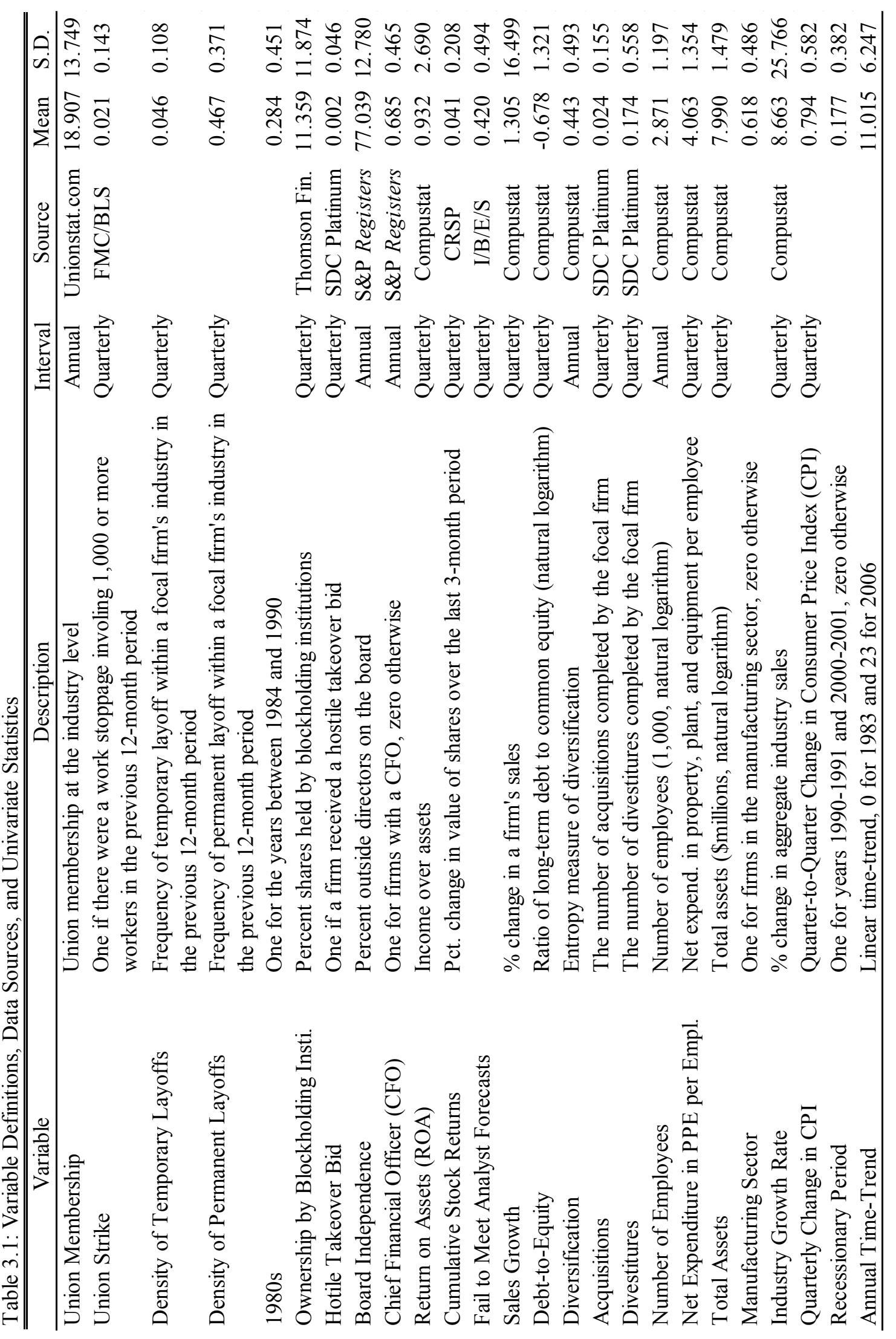


asset size is also controlled for.

Several important aspects of macroeconomic or institutional contexts are also considered. First, quarter-to-quarter changes in the Consumer Price Index (CPI) tap overall macro economic conditions. Industry growth rate is measured as the percentage change in the aggregate sales for each 2-digit SIC industry the firm operates in. Aggregate sales were calculated using information for all companies in Compustat. An indicator variable for recessionary periods (1990-1991 and 2000-2001) is included. An annual time-trend variable is included to capture the effect of unmeasured secular trends.

\subsubsection{Missing Values and Multiple Imputation}

For some explanatory and control variables, missing values are of concern. The most severe case is the ROA variable; for about 18 percent of all quarterly intervals, this information is not available. The amount of missing data is also reported in Table 3.1. When the data are missing for reasons that are not completely random, list-wise deletion tends to yield biased estimates (Allison 2002). To address this problem, I impute missing values using multiple imputation, using a R package called Amelia II (King et al. 2001). It predicts missing values from the complete data but adds to the predicted value a random error from a normal distribution. Hence, it generates $\mathrm{N}$ different data sets, each containing different imputed values for the missing component. For a moderate number of missing cases (e.g., 10 to 20 percent), 5 to 10 data sets are usually sufficient. 10 data sets were generated for the present study. The resulting coefficients and standard errors are combined using the formula in King et al. (2001, p. 53).

\subsubsection{Modeling Procedure}


I analyze layoff announcements between 1984 and 2006, using a continuous-time event history analysis. Announcement-spells are defined as the time intervals between announcements; hence, the duration time is reset to zero every time an event occurs. The metric for duration is day, which is fine-grained enough for continuous-time models. Since firms in the sample typically made more than one layoff announcement, the total number of announcement-spells exceeds the number of firms. I split each spell into quarterly intervals so that time-varying predictors are updated on a quarterly basis. Predictors are lagged to avoid the problem of rate dependence, that is, a time-varying predictor's value at time $t$ is affected by the subject's hazard rate. Hence, for those variables that vary quarterly (annually), they reflect the state in the previous quarter (year).

For many firms, their first spells are left-truncated. Left-truncation can be handled properly, as long as one knows the reference for the onset of the left-truncated spells-the date of the last layoff announcement in the current case. For each left-truncated spell, I searched beyond 1984 to identify the date of the previous announcement. However, this was done only up to January 1st, 1980; prior to this point, media coverage of layoff announcements available from Lexis/Nexis was very sparse and, even when available, not detailed enough to distinguish between temporary and permanent layoffs. Therefore, for those spells (448 for temporary layoff and 381 for permanent layoff), the beginning point was set to January 1st, 1980. I conducted a robustness check by estimating models without those spells, which is the most common method for handling the problem of left-truncation (Singer and Willett 2003). The results were qualitatively the same.

I use a Cox regression model for estimation. The Cox model is a widely used method for continuous-time event history analysis, because it incorporates a flexible framework for studying the duration until each event; unlike other parametric models, it does not require researchers to 
choose some particular probability distribution to represent survival times (Allison 1995). Without having much prior knowledge, any choice of the functional form for the baseline hazard function would be arbitrary. Instead, the Cox regression model lets the data determine the shape of the hazard function (Allison 1995). Given the two alternative forms of layoff-temporary and permanent-I run separate event history models for each form of layoff (Box-Steffensmeier and Jones 2004, p. 168-9).

The repeatability of the event under study requires special treatment; there can be dependence among the multiple observations from the same unit, arising from unobserved heterogeneity (Allison 1995, p. 240). To address this issue, I use the fixed-effects Cox regression, which lets announcement-spells of the same firm share the same baseline hazard function. Allison (1996, p. 220) suggests that the fixed-effects estimator addresses repeatable events better than conventional single-event approaches and, by accounting for all unobserved subject-specific characteristics, enables one to make a more stringent causal argument. One shortfall of this model is that it is most feasible when most subjects under study experience an event more than once. This is the case with permanent layoffs but not for temporary layoffs. In fact, only 97 firms out the total sample of 681 made a temporary-layoff announcement at least once, while 582 firms made a permanent-layoff announcement. Hence, I conduct robustness checks using a randomeffects variant of Cox model, which, unlike the fixed-effect model, does not drop subjects that do not experience (Box-Steffensmeier and Jones 2004, p. 162-6). The results are mostly similar to those from the fixed-effects model.

\subsection{RESULTS}


My data of layoff announcements demonstrate significant changes in layoff policies of large U.S. corporations since the 1980s. Figure 2.1 plots average count of the number of layoffs announced by all sampled firms from 1980 to 2006 . There are two noticeable trends. First, layoff announcements have become more frequent. Whereas, during the recession in the early $1980 \mathrm{~s}$, firms on average made about 0.4 layoff announcement (including both temporary and permanent layoffs), during the recession in the early 2000 s, firms on average made more than one announcement. Second and more importantly, announced layoffs have been predominantly permanent ones. Early on, the ratio of temporary to permanent layoffs was close to one, but it has come down to 0.1 in the later period. The same pattern is observed, in a more dramatic way, in the transportation equipment industry, a stronghold of the UAW, probably the most influential industrial union in the U.S. (see Figure 2.2). There, temporary layoffs were more commonly seen than permanent ones in the early 1980s and persisted throughout the 1980s. But they declined rapidly afterwards.

\subsubsection{Union Resistance and Public Policy}

Table 3.2 presents the event-history models of temporary and permanent layoffs. The results generally support my hypotheses about how the policy regime in the 1980s affects the influence of labor unions and the effect of density-dependent legitimation process. To begin with the influence of unions, there is some evidence that it helped maintain temporary layoffs and discouraged permanent layoffs, but such effects were critically contingent on the public policy regime. In Model 1, neither union member nor union strike activity significantly affects the rate of temporary layoff. With an interaction term with the period indicator for the 1980s added in Model 2, union membership has a significant positive main effect. But its interaction has a 


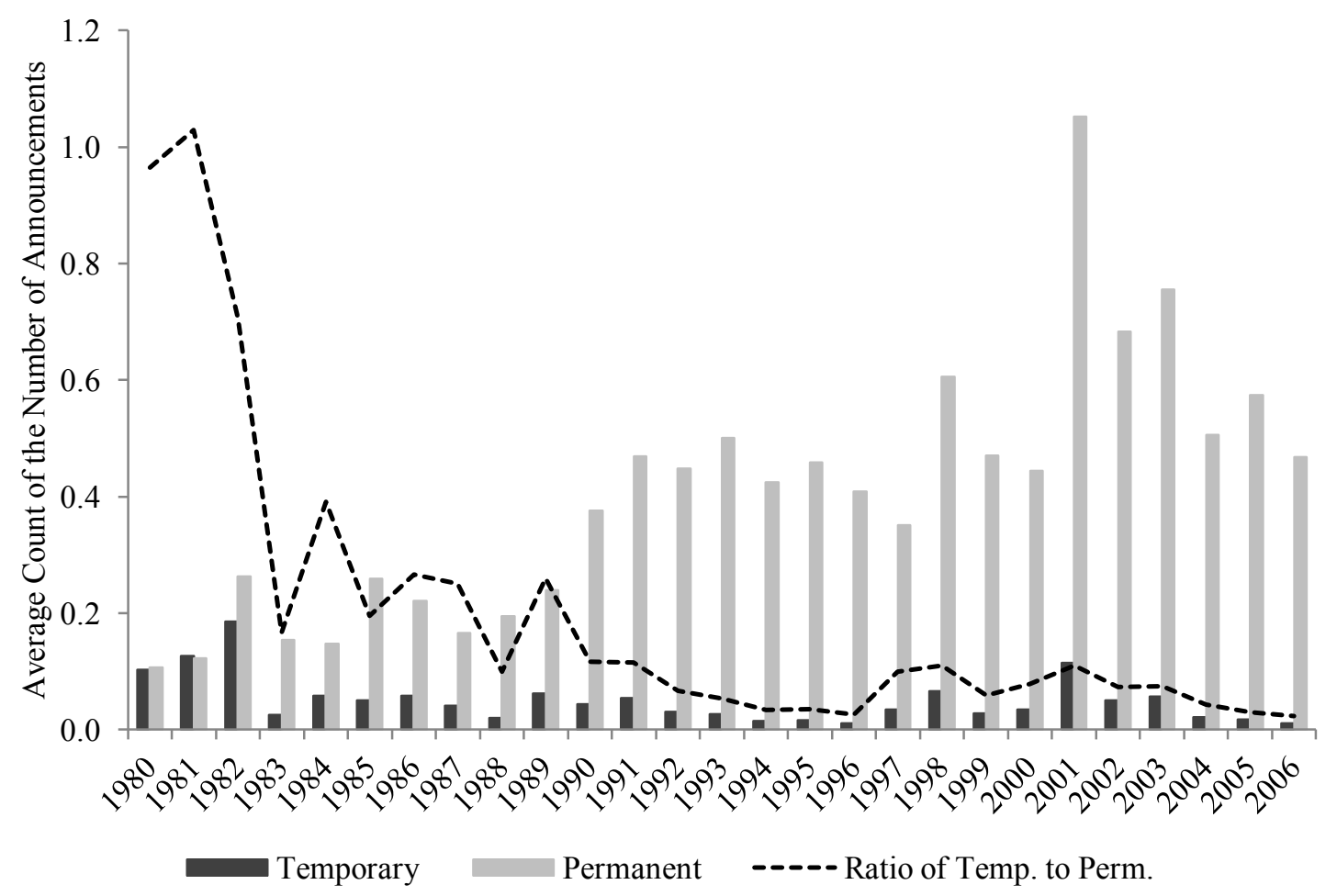

Figure 3.1: Temporary and Permanent Layoff Announcements (All Sampled Firms)

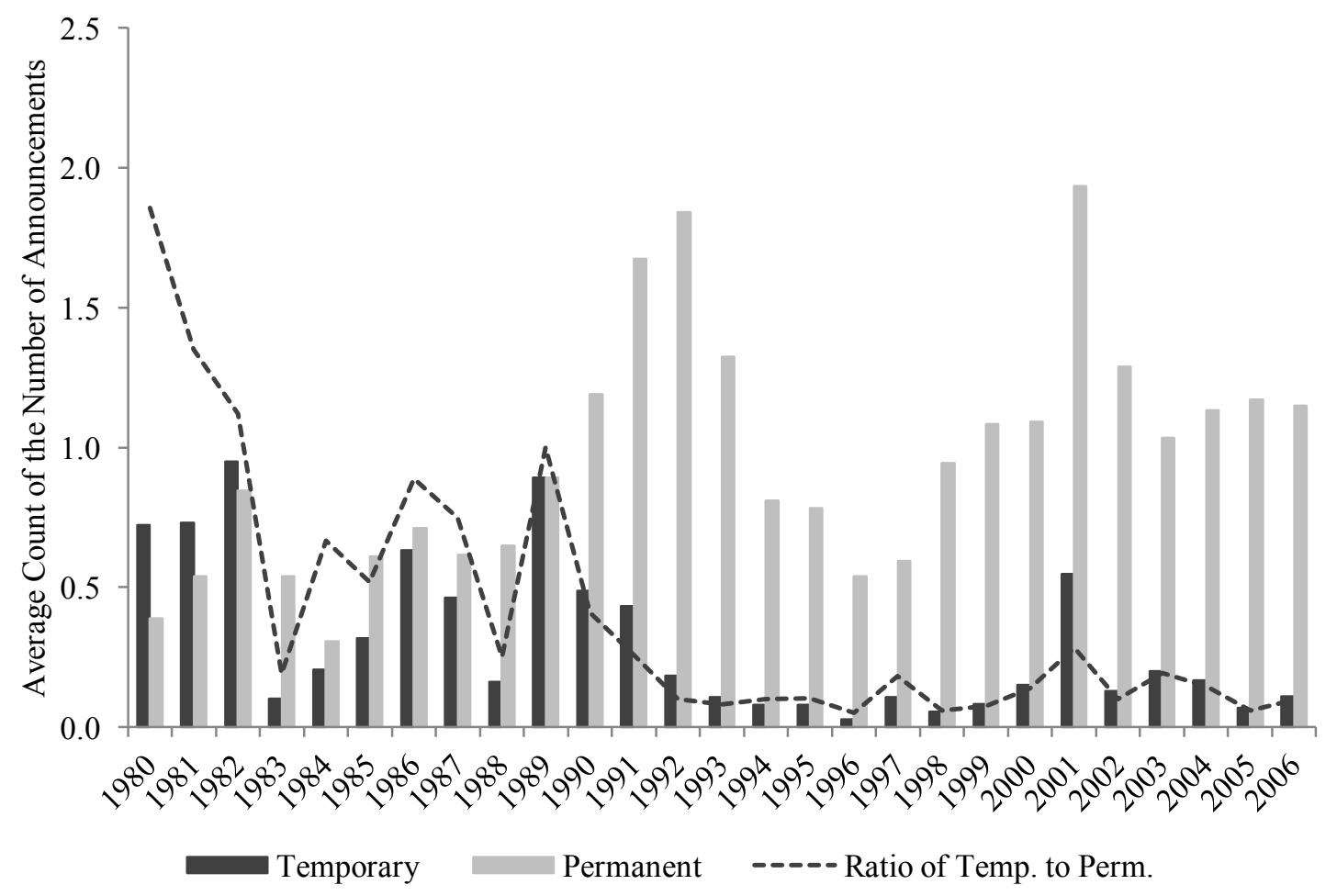

Figure 3.2: Temporary and Permanent Layoff Announcements (Firms in the Transportation Equipment Industry) 
significantly negative one, which suggests that the ability of unions to maintain temporary layoff was significantly undermined in the 1980s. After the 1980s, they regained some of their influence so that temporary layoff continued at least within union strongholds. Specifically, one percent increases in union membership increases the hazard rate by about 4.6 percent $(100 *[\exp (0.045)-1] ; \mathrm{p}<0.05)$. A similar interaction pattern is not observed for union strike activity in the case of temporary layoff.

The influence of labor unions also discouraged permanent layoffs, but, again, their influence was significantly contingent on the public policy regime. As is the case with temporary layoff, there is no significant main effect of union membership and union strike activity on the rate of permanent layoff. With an interaction term with the period indicator in Model 5, the main term for union strike activity becomes negative and statistically significant. Specifically, the rate of permanent layoff for firms that experienced a work stoppage in the previous year is about 22 percent $(=100 *[\exp (-0.249)-1] ; \mathrm{p}<0.05)$ less than that of firms that did not. But the interaction term has a significant, positive coefficient, which implies that union strike activity was not as effective in preventing permanent layoffs in the 1980s as it was in the later period. Note also that there is no similar negative effect of union membership on the rate of permanent layoff. It seems that it requires more direct confrontational tactics to block permanent layoffs, than the mere presence of unions.

\subsubsection{Density-Dependent Legitimation and Public Policy}

Turning to the density-dependent legitimation process, there is also strong evidence that public policy significantly affects its outcome. As expected, in Models 1 and 4, the density of each type of layoff increases the rate of the same type, respectively. Further analyses in Models 3 and 6, 
Table 3.2: Event-History Analysis of Temporary versus Permanent Layoff Announcements

\begin{tabular}{|c|c|c|c|c|c|c|}
\hline \multirow[b]{3}{*}{ Union Membership } & \multicolumn{6}{|c|}{ Temporary Layoff } \\
\hline & \multicolumn{2}{|c|}{ Model 1} & \multicolumn{2}{|c|}{ Model 2} & \multicolumn{2}{|c|}{ Model 3} \\
\hline & 0.021 & $(0.016)$ & $0.045^{*}$ & $(0.018)$ & 0.026 & $(0.016)$ \\
\hline 1980s $\times$ Union Membership & & & $-0.044 * * *$ & $(0.012)$ & & \\
\hline Union Strike & -0.225 & $(0.245)$ & -0.450 & $(0.356)$ & -0.119 & $(0.250)$ \\
\hline 1980s $\times$ Union Strike & & & 0.319 & $(0.491)$ & & \\
\hline Density of Temporary Layoffs & $3.639 * * *$ & $(0.747)$ & $3.485 * * *$ & $(0.751)$ & $4.139 * * *$ & $(0.974)$ \\
\hline 1980s $\times$ Temporary Layoff Density & & & & & $-4.068 * *$ & $(1.503)$ \\
\hline Density of Permanent Layoffs & -0.237 & $(0.325)$ & -0.352 & $(0.328)$ & -0.237 & $(0.342)$ \\
\hline 1980s $\times$ Permanent Layoff Density & & & & & $3.783 * * *$ & $(0.935)$ \\
\hline Period 1980s & $0.817 * * *$ & $(0.226)$ & $2.462 * * *$ & $(0.508)$ & -0.182 & $(0.364)$ \\
\hline Ownership by Blockholding Instit. & $2.870 * *$ & $(0.946)$ & $2.964 * *$ & $(0.947)$ & $3.090 * *$ & $(0.958)$ \\
\hline Hotile Takeover Bid & -0.410 & $(1.064)$ & -0.452 & $(1.076)$ & -0.207 & $(1.049)$ \\
\hline Board Independence & -0.906 & $(0.920)$ & -0.102 & $(0.959)$ & -0.887 & $(0.939)$ \\
\hline Chief Financial Officer (CFO) & $-0.465^{*}$ & $(0.192)$ & $-0.477^{*}$ & $(0.198)$ & $-0.401^{*}$ & $(0.197)$ \\
\hline Return on Assets (ROA) & -0.022 & $(0.028)$ & -0.021 & $(0.029)$ & -0.014 & $(0.029)$ \\
\hline Cumulative Stock Returns & $-1.633 * * *$ & $(0.327)$ & $-1.610 * * *$ & $(0.329)$ & $-1.598 * * *$ & $(0.326)$ \\
\hline Fail to Meet Analyst Forecasts & $0.343 * *$ & $(0.119)$ & $0.315^{* *}$ & $(0.120)$ & $0.334 * *$ & $(0.120)$ \\
\hline Sales Growth & -0.005 & $(0.005)$ & -0.005 & $(0.005)$ & -0.006 & $(0.005)$ \\
\hline Debt-to-Equity & $0.181^{*}$ & $(0.084)$ & 0.145 & $(0.085)$ & $0.171^{*}$ & $(0.085)$ \\
\hline Diversification & -0.235 & $(0.365)$ & -0.314 & $(0.366)$ & -0.166 & $(0.362)$ \\
\hline Acquisitions & 0.678 & $(0.483)$ & 0.660 & $(0.481)$ & 0.688 & $(0.482)$ \\
\hline Divestitures & -0.155 & $(0.122)$ & -0.158 & $(0.121)$ & -0.193 & $(0.122)$ \\
\hline Number of Employees & $1.457 * * *$ & $(0.312)$ & $1.524 * * *$ & $(0.318)$ & $1.414 * * *$ & $(0.322)$ \\
\hline Net Expenditure in PPE & -0.199 & $(0.296)$ & -0.309 & $(0.300)$ & -0.080 & $(0.307)$ \\
\hline Total Assets & 0.026 & $(0.267)$ & -0.049 & $(0.271)$ & -0.176 & $(0.276)$ \\
\hline Quarterly Change in CPI & $-0.401 * * *$ & $(0.103)$ & $-0.414 * * *$ & $(0.103)$ & $-0.427 * * *$ & $(0.105)$ \\
\hline Recessionary Period & $0.515^{* * *}$ & $(0.146)$ & $0.460 * *$ & $(0.147)$ & $0.468 * *$ & $(0.149)$ \\
\hline Industry Growth Rate & 0.002 & $(0.003)$ & 0.003 & $(0.003)$ & 0.00001 & $(0.003)$ \\
\hline Annual Time-Trend & $0.061^{*}$ & $(0.029)$ & $0.087 * *$ & $(0.030)$ & 0.058 & $(0.030)$ \\
\hline Log Likelihood & $-1,237$ & .325 & $-1,22$ & .146 & $-1,228$ & .646 \\
\hline No. Quarterly Intervals & 7,0 & & 7,0 & & 7,0 & \\
\hline No. Announcement Events & 42 & & 42 & & 42 & \\
\hline No. Firms & 97 & & 9 & & 9 & \\
\hline
\end{tabular}

$* \mathrm{p}<0.05 ; * * \mathrm{p}<0.01 ; * * * \mathrm{p}<0.001$ (two-sided tests) 
Table 3.2 (Continued)

\begin{tabular}{|c|c|c|c|c|c|c|}
\hline \multirow[b]{3}{*}{ Union Membership } & \multicolumn{6}{|c|}{ Permanent Layoff } \\
\hline & \multicolumn{2}{|c|}{ Model 4} & \multicolumn{2}{|c|}{ Model 5} & \multicolumn{2}{|c|}{ Model 6} \\
\hline & 0.005 & $(0.004)$ & 0.004 & $(0.004)$ & 0.004 & $(0.004)$ \\
\hline 1980s $\times$ Union Membership & & & 0.002 & $(0.004)$ & & \\
\hline Union Strike & -0.098 & $(0.086)$ & $-0.249^{*}$ & $(0.101)$ & -0.099 & $(0.086)$ \\
\hline 1980s $\times$ Union Strike & & & $0.583 * *$ & $(0.187)$ & & \\
\hline Density of Temporary Layoffs & $1.467 * * *$ & $(0.233)$ & $1.409 * * *$ & $(0.234)$ & $1.196^{* * *}$ & $(0.257)$ \\
\hline 1980s $\times$ Temporary Layoff Density & & & & & $-1.150 *$ & $(0.533)$ \\
\hline Density of Permanent Layoffs & $0.610 * * *$ & $(0.088)$ & $0.625^{* * *}$ & $(0.088)$ & $0.674 * * *$ & $(0.090)$ \\
\hline $1980 \mathrm{~s} \times$ Permanent Layoff Density & & & & & $2.130 * * *$ & $(0.424)$ \\
\hline Period 1980s & $-0.856 * * *$ & $(0.067)$ & $-0.950 * * *$ & $(0.114)$ & $-1.382 * * *$ & $(0.115)$ \\
\hline Ownership by Blockholding Instit. & $0.793 * *$ & $(0.250)$ & $0.788^{* *}$ & $(0.250)$ & $0.801 * *$ & $(0.250)$ \\
\hline Hotile Takeover Bid & $0.894 * *$ & $(0.284)$ & $0.902 * *$ & $(0.285)$ & $0.915^{* *}$ & $(0.285)$ \\
\hline Board Independence & $0.810^{* *}$ & $(0.250)$ & $0.807 * *$ & $(0.251)$ & $0.831 * * *$ & $(0.252)$ \\
\hline Chief Financial Officer (CFO) & $0.257 * * *$ & $(0.053)$ & $0.262 * * *$ & $(0.053)$ & $0.255^{* * *}$ & $(0.053)$ \\
\hline Return on Assets (ROA) & $-0.064 * * *$ & $(0.007)$ & $-0.064 * * *$ & $(0.007)$ & $-0.064 * * *$ & $(0.007)$ \\
\hline Cumulative Stock Returns & $-0.752 * * *$ & $(0.086)$ & $-0.750 * * *$ & $(0.086)$ & $-0.735 * * *$ & $(0.086)$ \\
\hline Fail to Meet Analyst Forecasts & $0.291 * * *$ & $(0.033)$ & $0.291 * * *$ & $(0.033)$ & $0.289 * * *$ & $(0.033)$ \\
\hline Sales Growth & -0.001 & $(0.001)$ & -0.001 & $(0.001)$ & -0.001 & $(0.001)$ \\
\hline Debt-to-Equity & $0.086^{* * *}$ & $(0.022)$ & $0.086^{* * *}$ & $(0.022)$ & $0.088 * * *$ & $(0.022)$ \\
\hline Diversification & $-0.170 *$ & $(0.075)$ & $-0.153 *$ & $(0.076)$ & -0.147 & $(0.076)$ \\
\hline Acquisitions & $0.581 * * *$ & $(0.086)$ & $0.583 * * *$ & $(0.086)$ & $0.585^{* * *}$ & $(0.086)$ \\
\hline Divestitures & $0.049 *$ & $(0.022)$ & $0.049^{*}$ & $(0.022)$ & $0.048 *$ & $(0.022)$ \\
\hline Number of Employees & $1.694 * * *$ & $(0.099)$ & $1.694 * * *$ & $(0.099)$ & $1.670^{* * *}$ & $(0.098)$ \\
\hline Net Expenditure in PPE & $0.513 * * *$ & $(0.075)$ & $0.520 * * *$ & $(0.075)$ & $0.503 * * *$ & $(0.074)$ \\
\hline Total Assets & $-0.304 * * *$ & $(0.080)$ & $-0.307 * * *$ & $(0.080)$ & $-0.291 * * *$ & $(0.080)$ \\
\hline Quarterly Change in CPI & $-0.125 * * *$ & $(0.026)$ & $-0.125 * * *$ & $(0.026)$ & $-0.130 * * *$ & $(0.026)$ \\
\hline Recessionary Period & $0.429 * * *$ & $(0.038)$ & $0.433 * * *$ & $(0.038)$ & $0.423 * * *$ & $(0.038)$ \\
\hline Industry Growth Rate & $-0.004 * * *$ & $(0.001)$ & $-0.003 * * *$ & $(0.001)$ & $-0.004 * * *$ & $(0.001)$ \\
\hline Annual Time-Trend & $0.035^{* * *}$ & $(0.007)$ & $0.034 * * *$ & $(0.007)$ & $0.030 * * *$ & $(0.007)$ \\
\hline Log Likelihood & $-15,63$ & 4.277 & $-15,62$ & .107 & $-15,61$ & 5.088 \\
\hline No. Quarterly Intervals & 38 & & $38, ?$ & & 38 & \\
\hline No. Announcement Events & 4,9 & & 4,9 & & 4,9 & \\
\hline No. Firms & 52 & & 52 & & 52 & \\
\hline
\end{tabular}

$* \mathrm{p}<0.05 ; * * \mathrm{p}<0.01 ; * * * \mathrm{p}<0.001$ (two-sided tests) 
however, demonstrate that the policy regime in the 1980s significantly altered the positive effect of form-specific density measures. On the one hand, in Model 4, the positive effect of temporary-layoff density on the rate of the same type of layoff is significantly reduced in the 1980s. Combined with the interaction term with the period indicator for the 1980s, its coefficient becomes close to zero $(0.071=4.139-4.068)$, meaning that its significantly positive effect is limited only to the period after the 1980s. It seems that the anti-union stance of the government in the 1980s negatively affected the cognitive-cultural legitimacy of temporary layoff, which was preferred by labor unions; as a result, firms stopped considering it serious even when some other firms in the same industry continued the practice. On the other hand, in Model 6, the positive effect of permanent-layoff density on the rate of the same type of layoff is significantly reinforced. The combined coefficient for the 1980 s (i.e., $2.804=0.674+2.130$ ) is significantly larger than the main effect for the period after the 1980s (i.e., 0.674). This pattern suggests that the strong pro-business stance of the government in the 1980s strengthened management's ability to make permanent adjustment to workforce size, whenever they saw it necessary.

Contrary to my predictions, however, there is little evidence that the density of one type of layoff decreases the rate of the other type. In Model 1, the density of permanent layoff does not decrease the rate of temporary layoff. Moreover, in Model 4, the density of temporary layoff significantly increases, not decreases, the rate of permanent layoff. Therefore, for the case at hand, the density of one type of layoff mostly legitimizes, rather than delegitimizes, the other form. Nevertheless, the results reported in Models 3 and 6 suggest that these effects are also significantly contingent on the public policy regime. First, when combined with the period indictor for the 1980s in Model 3, the coefficient for the density of permanent layoff become significantly positive $(3.546=-0.237+3.783)$, meaning that it has a positive effect on the rate of 
temporary in the 1980s. Second, the combined coefficient with the period indicator in Model 6 is close to zero $(0.046=1.196-1.150)$, meaning that the positive effect of temporary-layoff density on the rate of permanent layoff is limited only to the period after the 1980s. These results, together, suggest that the cultural-cognitive legitimacy of temporary layoff was significantly undermined after the 1980s. In the 1980s, some firms seeking to adjust workforce continued to turn to temporary layoff when many others within the same sector turned away from it and towards permanent layoff. This was not the case anymore after the 1980s. In that period, most firms turned to permanent layoff even when some other firms in the same sector tried temporary layoff.

\subsubsection{Control Variables}

Most control variables have an expected effect. First of all, all of my measures of a firm's shareholder-value orientation increase the rate of permanent layoff. Some of them—ownership by blockholding institutions and failure to meet analyst forecasts - also increase the rate of temporary layoff, but others have no significant effect, except for the CFO variable that has a significantly negative effect. As for other control variables, poor firm performance, large workforce, other corporate restructuring events (acquisitions and divestitures), and worsening macroeconomic conditions generally increase the hazard rate of both temporary and permanent layoffs. Reflecting the trend in Figure 1, temporary layoffs become less frequent over time, while permanent layoffs become more frequent.

\subsection{CONCLUSION}


In the 1980s, the layoff policies of many large U.S. companies changed from temporary suspension of employment to permanent termination. While firms once temporarily laid off workers during economic downturns and recalled them when the overall economic conditions improved, now even firms with healthy profits cut jobs on a massive scale in a bid to impress the financial community. Previous studies suggest that powerful shareholders and shareholder-value oriented managers promoted this change, and that, although initially contested, it was gradually taken for granted (Budros 1997; 2002; Fligstein and Shin 2007; Hirsch and De Soucey 2006). In suggesting this, however, these previous studies leave out an important aspect of the processthe resistance from workers and their unions. This paper fills in the gap in the sociological literature of downsizing. I explore the role of labor unions in resisting the change and explain why their resistance failed to prevent it. My findings suggest that unions attempted not only to maintain temporary layoff but also to discourage permanent layoff, but that their ability to do both was significantly curtailed in the 1980s by the government's anti-labor, pro-business stance.

One of the two main theoretical contributions of this paper is to elaborate the role played by public policy in institutional change, through its influence over inter-group power struggles. Although the United States is often regarded as an example of a weak state, it exerts considerable influence over the behavior, by shaping and reshaping the institutional environment of firms in favor of certain groups over others (Campbell and Lindberg 1990; 1997; Dobbin and Dowd 2000; Dobbin and Sutton 1998; Fligstein 1990; 2001). My analysis of layoff policies in large U.S. firms provides another piece of supportive evidence. My findings suggest that the anti-union, pro-business approach of the Reagan Administration facilitated the transition from temporary to permanent layoff, precisely by affecting the balance of power between management and labor. This effect of public policy, although indirect, proved to be enduring. 
Although the stance of subsequent administrations towards labor unions became less confrontational, permanent layoff continued to prevail over temporary layoff long after the Reagan era.

The other theoretical contribution of this paper is to explore the inter-relationships between Scott's (1995) three sources of legitimacy_regulative, normative, and culturalcognitive ones. The role of the state in conferring or withdrawing legitimacy has been extensively studied (Baum and Oliver 1991; 1992; Dobbin and Dowd 1997; Fligstein 1990; Ingram and Simons 2000; Ruef and Scott 1998; Simons and Ingram 2003). Building on the previous studies, my analysis examines how this regulative legitimacy reinforces other sources of legitimacy - in this case, cognitive-cultural legitimacy. While it is a widely accepted that the prevalence of a given organizational structure or practice indicates its cognitive-cultural legitimacy (Hannan and Freeman 1989; Tolbert and Zucker 1983), this paper explores how public policy affects this density-dependent process. I show that the anti-union, pro-business stand of the U.S. government in the 1980s reinforced the legitimation process for permanent layoff but dampened the process for temporary layoff. Hence, in the 1980s, firms engaged in permanent layoff when many of their industry peers did the same but not in temporary layoff even when other firms did.

Further research on the role of public policy in institutional change is warranted, especially given the contested nature of institutional change itself. While early work tends to describe institutional change as an apolitical process driven by taken-for-granted cognitive schemas and common cultural norms, more recent work emphasizes political aspects of the process, involving competing interest groups within as well as without of organizations (Clemens and Cook 1999; Friedland and Alford 1991; Kim et al. 2007; King and Pearce 2010; 
Pache and Santos 2010; Seo and Creed 2002). According to these studies, institutional change results from inter-group politics involving not only those who push for change but also those who maintain the status quo (Ahmadjian and Robbins 2005; Fiss and Zajac 2004; Ingram and Rao 2004; Schneiberg and Bartley 2001). This emphasis on political process helps overcome the criticism that early work pays insufficient attention to the role of agency and power (DiMaggio 1988; Mizruchi and Fein 1999; Perrow 1986). At the same time, however, the new emphasis raises the thorny issue of what social and political conditions and processes determine the outcome of inter-group power struggle, which ultimately determines the course and outcome of institutional change. The findings of this paper suggest that public policy can play a crucial role in this regard, by shaping the "political opportunity structure" for different groups (McAdam 1982). My findings suggest that the policy regime in the 1980s significantly contributed to the shift from temporary to permanent layoff by weakening the influence of labor unions and ideologically supporting the latter form of layoff. Future research could usefully examine how political struggles among interest groups over the course of institutional change shift under different policy regimes.

The resistance from unions, although it fell short of preventing the shift from temporary to permanent layoff in the 1980s, nonetheless reveals the political tension over the change. In fact, the effect of union membership and strike activity on the rate of both temporary and permanent layoff after the 1980s is remarkable, despite the waning political influence of labor unions. Because union membership declined steadily from its peak in the 1960s, and the level of strike activity slid precipitously in the 1980s, skeptics might expect no significant effect of labor unions on firms' decision about layoffs. Indeed, what occurred in the 1980s under the anti-union, pro-business policy regime seems to confirm this view; my analysis shows that neither union 
membership nor strike activity affected both forms of layoff in the 1980s. What happened after the 1980s, however, suggests something quite different. Unions, although indeed significantly weakened, still provided some buffer against the spread of massive layoffs. My results demonstrate that, after the 1980 s, union membership increased the rate of temporary layoff and that strike activity decreased the rate of permanent layoff. Whether these findings reflect the revitalization of the union movement in the 1990s (Clawson and Clawson 1999; Voss and Sherman 2000) or more conciliatory approaches of firms to unions in the improving economic conditions of the 1990s, they demonstrate that unions clearly played an important role and thus strong suggest that their role should not neglected. 


\section{MULTIPLE INSTITUTIONAL DEMANDS AND IMPLEMENTATION OF WORKFORCE DOWNSIZING BY FIRMS}

Since Meyer and Rowan's (1977) and DiMaggio and Powell's (1983) seminal papers, organizational institutionalists have done extensive research on diffusion of formal structure and policies across organizations. Meyer and Rowan (1977) posit that organizations adopt externallylegitimized practices in order to achieve legitimacy in the eyes of important constituents including customers, suppliers, competitors, and regulatory agencies. Building on this initial insight, DiMaggio and Power (1983) propose three theoretical mechanisms-coercive, mimetic and normative- through which such externally-legitimized practices diffuse from one organization to another. Studies have shown that organizations within a given field become homogeneous as they adopt similar practices (Dobbin and Sutton 1998; Edelman 1990; Fligstein 1985; Haveman 1993; Henisz, Zelner, and Guillen 2005; Mezias 1990; Tolbert and Zucker 1983).

Despite their contribution to our understanding of the normative dimension of organizational behavior, however, these studies mostly focus on the adoption of policies and fail to consider implementation. This is regrettable in that more research is needed regarding policy implementation as a critical stage of institutional change (Campbell 2004; Halliday and Carruthers 2009). Studies that examine how formally adopted policies are implemented show that there is considerable variation in the way that such policies are actually implemented (Fiss and Zajac 2004; Weber, Davis, and Lounsbury 2009; Westphal, Gulati, and Shortell 1997; Westphal and Zajac 2001; Zbaracki 1998). In addition, recent studies that have examined policy implementation suggest that it is a highly contentious process, even more so than policy adoption, involving opponents as well as supporters of a given policy (Halliday and Carruthers 2009; 
Henisz and Zelner 2005; Zelner, Henisz, and Holburn 2009). Without considering the implementation stage, therefore, one might risk overestimating the extent to which institutional diffusion makes organizations homogenous, while underestimating the contested nature of the institutional change.

In this paper, I develop a socio-political account of policy implementation. I build on the notion that organizations are embedded in a complex web of power relations involving competing interest groups (Dobbin and Dowd 2000; Friedland and Alford 1991; Granovetter 1985; Mintz and Schwartz 1985; Prechel 2000; Roy 1997). I discuss how being embedded in multitudinal power relations constrains as well as enhances the ability of organizations to implement formally adopted policies. In general, sustained pressure from supporters of a given policy limits their ability to not implement the adopted policy, while resistance from opponents constrains their ability to implement the same policy. Intra-organizational groups also play a significant role in the presence of such conflicting demands, choosing to implement adopted policies only when doing so serves their own interests. By considering the influence of politicalstructural factors on policy implementation, I depart from an approach that focuses on the strategic motivations of organizations. It has been suggested that organizations actively manage conflicting demands arising from multiple institutional logics by formally adopting policies without implementing them fully (Boxenbaum and Jonsson 2008; Meyer and Rowan 1977; Oliver 1991). In fact, prior research shows that such a "decoupling" strategy is prevalent in the presence of conflicting institutional demands (Basu, Dirsmith, and Gupta 1999; Edelman 1992; Elsbach and Sutton 1992; Kostova and Roth 2002; Westphal and Zajac 1998). But I argue that there exist limits on the extent to which organizations can appease institutional demands by 
decoupling, and that the tension resulting from conflicting demands can also constrain the ability of organizations to move strategically.

I test my argument with an analysis of the implementation of workforce downsizing plans announced by leading U.S. firms. This provides an ideal case for testing how conflicting institutional demands affect the ability of firms to implement formally adopted policies. Since the 1980s, leading U.S. firms have begun to announce massive downsizing plans under the banner of maximizing shareholder value, but there remains skepticism about how seriously firms implement these plans. Even when firms actually implement them, the magnitude of workforce reduction may fall short of what is announced. I argue that this uncertainty over the implementation of downsizing reflects the influence of groups with conflicting interests in and around the firm. Shareholders, often represented by large institutional investors who have been staunch advocates of the logic of shareholder primacy, have actively promoted downsizing as a means of enhancing corporate performance; at the same time, employees represented by labor unions have fiercely resisted the logic of shareholder primacy and hence the idea that jobs can be sacrificed to enhance shareholder value. Additionally, managers may not actively embrace the logic of shareholder primacy but may nonetheless engage in and implement downsizing, so long as it serves their own interests.

Using a sample of 694 companies between 1984 and 2005, I examine how these three interest groups influence two aspects of implementation - the post-announcement reduction in overall employment size and the reduction in the relative proportion of managerial workforce. My results demonstrate the contrasting influences of the three groups, which in turn reflect their conflicting interests regarding the implementation of downsizing. Such findings suggest that 
firms are embedded in a delicate web of power relations, and that multiple, often conflict institutional demands inherent in such a web can constrain their ability to act strategically.

\subsection{CONFLICTING INSTITUTIONAL DEMANDS AND POLICY IMPLEMENTATION}

Policy implementation (whether and how organizations implement formally adopted policies), although less studied than policy adoption, was raised as one of the central issues at the beginning of organizational institutionalism. In their seminal paper, Meyer and Rowan (1977) suggest that when organizations adopt new policies in order to conform to the demands of their external constituents, which may be expressed as legal mandates or simply as public opinion, such policies can conflict with core technical activities of those organizations. To avoid such tensions, they suggest, organizations decouple formally adopted policies from other core activities. As such, decoupling was initially discussed to indicate the need for organizations to conform to externally legitimized demands, but subsequent research has instead emphasized the strategic aspect of decoupling. In a widely cited paper, Oliver (1991) adds to the original insight from Meyer and Rowan this strategic consideration, suggesting that organizations can actively manage external demands, rather than passively conform to them, by strategically decoupling adoption from implementation when it is to their advantage.

Empirical studies have shown that various decoupling strategies indeed work well, when organizations are confronted with conflicting institutional demands (Elsbach and Sutton 1992; Westphal and Zajac 1994; 1998; Zajac and Westphal 2004). In a series of studies on executive compensation practices, Westphal and Zajac $(1994 ; 1998)$ show that management "symbolically" manage external demands from investors while still maintaining their discretion over executive 
compensation, by adopting but not fully implementing long-term incentive plans for chief executives. They show that even the mere adoption of such plans may lead to positive stockmarket reactions, regardless of its implementation (Westphal and Zajac 1998). This kind of symbolic management is especially prevalent when there are multiple institutional demands (Basu, Dirsmith, and Gupta 1999; Kostova and Roth 2002). For instance, organizations have to deal with multiple regulatory agencies that make conflicting demands. In such a case, symbolic management allows organizations to selectively address concerns of certain institutional constituents while making symbolic gestures to the remainder, so that the organizations save face with their constituents.

This kind of strategic view of decoupling enhances our understanding of the relationship between organizations and their institutional environments. Most importantly, it helps overcome one limitation of organizational institutionalism, namely its inattention to the strategic aspect of organizational response to institutional demands (Oliver 1991). At the same time, however, the strategic view risks overestimating an organization's ability to manage external demands and underestimating the constraints placed upon it by its institutional constituents. For one thing, there are limits on the extent to which organizations can appease institutional demands with only symbolic gestures, in the face of third-party monitoring or regulatory surveillance (Short and Toffel 2010; Zuckerman 1999). For another thing, while the presence of conflicting institutional demands can create latitude for organizations to exercise some level of strategic choice, by pitting one group of constituents against another (Clemens and Cook 1999; Dorado 2005; Seo and Creed 2002), the tension resulting from conflicting demands can also constrain an organization's ability to take decisive action (Pache and Santos 2010). Decoupling may, in fact, 
reflect an organization's inability to implement adopted policies, rather than its intentional decision not to implement.

Hence, to better understand policy implementation, one should attend to not only the strategic motivations of organizations, but also to the political-structural factors that can constrain as well as enhance an organization's ability to implement (or not implement) formally adopted policies. Organizations are embedded in a complex web of inter- and intraorganizational power relations (Dobbin and Dowd 2000; Friedland and Alford 1991; Granovetter 1985; Mintz and Schwartz 1985; Prechel 2000; Roy 1997). The resulting political tension significantly affects what organizations can and cannot do, especially in the presence of multiple, competing institutional logics (Dunn and Jones 2010; Friedland and Alford 1991; Marquis and Lounsbury 2007; Rao, Monin, and Durand 2003; Stryker 2000). Prior research on diffusion have shown that the presence of groups embracing competing logics can politicize the diffusion process, some facilitating the adoption of a given practice, others impeding it (Fiss and Zajac 2004; Greenwood et al. 2010; Ingram and Rao 2004; Schneiberg and Bartley 2001; Schneper and Guillen 2004). The availability of an alternative logic encourages institutional entrepreneurs to challenge the status quo (Marquis and Lounsbury 2007; Sine, Haveman, and Tolbert 2005). But at the same time, competition between logics prevents one logic from becoming predominant, making drastic changes or reforms difficult (Ahmadjian and Robbins 2005).

One would expect the political tension arising from conflicting demands also to have significant implications for policy implementation, probably even more so than for policy adoption. The inter-group tension at the point of adoption often continues or even intensifies during implementation (Halliday and Carruthers 2007; Henisz and Zelner 2005; Zelner, Henisz, and Holburn 2009). In a study of bankruptcy law reforms in developing countries, Halliday and 
Carruthers $(2007 ; 2009)$ demonstrate how contentious the implementation of formally adopted policies can be. Starting in the 1990s, in response to pressure from international organizations such as the International Monetary Fund and World Bank, many developing countries adopted a new bankruptcy law that met western standards. In many cases, however, local interest groups, such as local government officers and legal professionals, fiercely resisted radical reforms and attempted to defend their privileges. As a result, many key elements of the new bankruptcy regime were either repealed or compromised. Other studies on externally imposed reforms find similar patterns of retrenchment or lack of implementation (Hafner-Burton and Tsutsui 2005; Weber et al. 2009; Zelner, Henisz, and Holburn 2009).

The ability of organizations to implement a formally adopted policy is, then, critically dependent on the multitudinal power-relations in which the organizations are embedded. On the one hand, strict monitoring and continuing pressure from key institutional constituents is likely to discourage decoupling, by increasing the risk of punishment. On the other hand, resistance from other constituents who are negatively affected by a new policy can severely constrain the ability of organizations to implement formally adopted policies, even when they are genuinely willing to do so. Even if such groups fail to block the adoption of a policy that they resist, they may persist in their resistance by hindering its implementation. In the presence of such conflicting demands, one would expect the role of internal groups also to be crucial (Kim et al. 2007; Pache and Santos 2010). The outcome of policy implementation will depend on the interest of organizational decision makers after adoption; they may be initially enthusiastic about new policies, but, once they achieve the appearance of conformity, they may lose interest in implementing policies unless doing so serves their own interests. In the following, I apply this 
socio-political account to the implementation of workforce downsizing plans announced by leading U.S. firms.

\subsection{WORKFORCE DOWNSIZING AND ITS IMPLEMENTATION}

In response to growing pressure from shareholders, leading U.S. companies have invented and promoted various strategies to demonstrate their commitment to shareholder-value maximization, such as governance reforms and strategic changes (Dobbin and Zorn 2005). Workforce downsizing is another such strategy (Budros 1999; 2002; Fligstein and Shin 2007; Lazonick and O'Sullivan 2000). Traditionally, companies laid off employees, mostly on a temporary basis, during economic downturns (Cappelli 1999; Osterman 1999). Permanent downsizings were relatively rare, and large-scale ones were even rarer. This has drastically changed since the 1980s. Throughout the recessionary 1980s, downsizing became so prevalent that when the economic conditions improved in the mid-1990s, even profitable companies engaged in downsizing; many firms regarded it as an essential business strategy to maintain competitive cost structures (Hirsch and De Soucey 2006; Lazonick and O'Sullivan 2000). Fortune 500 companies like Kodak and Xerox announced massive downsizing plans even as they reported profits in the 1990s. In 1994, according to one estimate, while corporate profits rose $11 \%$ (after a $13 \%$ rise in 1993 ), corporate America cut 516,069 jobs; this was far more than in the recession year of 1990, when 316,047 jobs were eliminated (Murray 1995). While massive downsizing might have indicated failed management in the past, it has now become a measure that shows off management's "bareknuckled resolve" (Grimsley 1995).

The primary purpose of such downsizing is clearly to foster positive market reactions. Although the evidence of empirical studies is mixed (Caves and Krepps 1993; Hallock 1998; Lee 
1997; Palmon, Sun, and Tang 1997; Worrell, Davidson, and Sharma 1991), there are still many eye-catching cases of downsizing announcements leading to significant increases in stock price. The day when Sears announced it was discarding 50,000 jobs, its stock rose almost 4 percent; the day when Xerox said it would prune 10,000 jobs, its stock surged 7 percent (Uchitelle 1996). Given that firms tend to imitate their successful peers (Haveman 1993), these kinds of examples have tempted other firms to follow suit, in order to boost or restore share price. Previous studies show that a decline in share price is one of the most significant predictors of downsizing announcements in the 1990s (Budros 1997). Another indication that firms attempt to shape market reactions through downsizing announcements is the tendency of companies to announce a downsizing plan when they fail to meet securities analysts' forecasts. While stock price once fluctuated on the strength of actual profits, it now rises and falls on the strength of analyst forecasts of profits (Dobbin and Zorn 2005). The CEO of Sun Microsystems, when announcing a plan to cut 5,000 jobs in 2006, emphasized that the expected cost savings from the cuts would help the company meet the consensus analyst forecast, even though that forecast was of a loss of 2 cents a share (Flynn 2006).

Given this emphasis on apparent intention, an intriguing question is whether or to what degree firms actually implement their announced downsizing plans. Baumol and his colleagues (2003, p. 40-2) find that many firms that had announced a downsizing plan ended up with a labor force of roughly the same size or even larger than that before the announcement. This does not necessarily mean that companies attempt to cheat investors. What seems to occur, instead, is that companies rely on mere headcount cuts without making other difficult but necessary restructuring efforts (Gordon 1996; Harrison and Bluestone 1988). Consequently, when demand increases, such companies scramble to hire more employees (Prinstin 1998). Nevertheless, the 
finding by Baumol and his colleagues still suggests that downsizing is not fully implemented even though investors had been promised that it would be. Companies increasingly emphasize their downsizing plans as a part of broader restructuring efforts that entail drastic changes to workforce structure. The market also reacts positively to downsizing announcements framed in this way (De Meuse et al. 1994; Worrell et al. 1991). The fact that many firms end up with the same or even a larger workforce than before downsizing announcements, however, suggests that such drastic changes are unlikely to occur.

Less-than-full implementation is also apparent in the limited effect of downsizing on managerial jobs. Reducing the proportion of jobs not directly related to value-generating activities is one of the primary purposes of downsizing (Hammer and Champy 1993). Market reactions are also more likely to be positive when the announced downsizing involves a reduction in managerial jobs, suggesting that the market views such downsizing as creating value (Caves and Krepps 1993; Love and Nohria 2005). Nonetheless, research shows that downsizings do not lead to a significant reduction in managerial jobs (Baumol et al. 2003). One recent study even finds that the proportion of managerial jobs increases, rather than decreases, after downsizing, and suggests that this indicates the re-emergence of managerialism (Goldstein 2012). The implication may be that top managers are apathetic when it comes to streamlining overgrown managerial ranks (Gordon 1996).

\subsection{INTER-GROUP STRUGGLE OVER THE IMPLEMENTATION OF DOWNSIZING}

One possible reason for loose implementation of announced downsizing plans is that firms announce such plans mainly as a symbolic gesture to appease the financial community. It has 
been widely observed that the market often responds positively to announced policy changes even when those policies lack substantive plans for implementation (Westphal and Zajac 1998; Zajac and Westphal 2004). Companies may initially be interested in impressing market participants with drastic downsizing plans but, once this kind of impression management is accomplished, may become less interested in implementing such plans (Elsbach 1994; Elsbach and Sutton 1992). I suggest, however, below that this lax implementation also reflects political tensions resulting from conflicting external demands and the selective internal response to the conflicting demands. In particular, I attend to the influence of institutional investors, labor unions, and managers, over two post-announcement reductions involved in implementation: in the total number employees and in the proportion of managerial employees.

\subsubsection{Pressure from Institutional Investors}

Pressure from external constituents is one of the primary reasons for formal adoption of policies (DiMaggio and Powell 1983; Meyer and Rowan 1977). The question is whether such external groups continue to monitor and pressure organizations to implement the adopted policies. To the extent that they actually do, they discourage organizations from not implementing the adopted policy. Because of information asymmetry, such external monitoring may only be effective in a limited way. In the capital market, for instance, dispersed ownership reduces the ability and incentives of individual investors to monitor the behavior of managers (Berle and Means 1933). Concentration of share ownership, however, may enhance the effectiveness of external monitoring. What has been significant in this respect is the growth of market intermediaries, such as institutional investors, who have actively promoted the logic of shareholder-value maximization, and who over the past several decades, institutional investors have gained 
considerable influence over corporate decision-making (Dobbin and Jung 2012; Dobbin and Zorn 2005). Such investors, who, for example, manage large mutual funds or public pension assets, often own a large block of shares of a given company. Because of this, they cannot easily liquidate their holdings even when a company faces difficulty—any attempt to do so would further depress the value of their holdings—-and therefore have more incentive to monitor management than smallholding individual investors (Davis and Thompson 1994; Useem 1996).

Pressure from institutional investors has been a significant factor behind many recent corporate adoptions of workforce downsizing plans (Jung 2012), and such investors are unlikely to be satisfied only with plan adoption but are likely to be concerned with how the adopted plans are actually implemented. This is because downsizing plans are risky and will produce expected profit-boosting effects only when firms implement them as planned. Downsizing may improve the overall cost structure of firms, but it can be costly in the short run because firms usually have to incur considerable restructuring charges upfront (e.g., severance expenses). Studies suggest that most firms that engage in downsizing fail to improve profits even in the long run (Cascio, Young, and Morris 1997; De Meuse, Vanderheiden, and Bergmann 1994). Hence, institutional investors are likely to be highly concerned with the manner in which adopted downsizing plans are implemented over a considerable period of time, in order to ensure that anticipated cost savings are achieved.

Hypothesis 1: Pressure from institutional investors will accelerate post-announcement reduction in both the total number of employees and the proportion of managerial employees.

\subsubsection{Resistance from Labor Unions}


While external pressure from some constituents accelerates the implementation of policies, resistance from others has an opposite effect. Resistance from key constituents discourages the adoption of a given policy (Schneper and Guillen 2004), but even after the policy is formally adopted, their resistance may not subside soon. More often than not, formal adoption is only the beginning of a long process of institutional change. Recent studies on the local implementation of globally-diffusing policies illustrate this point well. Halliday and Carruthers (2009) show how local interest groups contested corporate bankruptcy reforms enacted by developing countries under international pressures, resulting in considerable differences in the way the reforms were implemented across countries. Zelner et al. (2009) document a similar case, in which national governments reinstated electricity-liberalization policies in response to negative public sentiment.

This kind of political dynamic can be expected, in the implementation of adopted downsizing plans, primarily through resistance from labor unions. In the postwar period, labor unions championed the industrial-union model of employment relations, where unions and employers set the rules regarding wages, benefits, working hours, job descriptions, and layoff terms (Kochan et al. 1994; Osterman 1999). In the 1980s, firms attempted to dismantle such rules and to evade collective bargaining (Meyer and Cooke 1993), but labor unions vehemently resisted such attempts. As a result, workforce downsizing has become an object of intense political struggle between employers and unions. Unions have attempted to prevent firms from implementing downsizing plans by using confrontational tactics such as work stoppages and, at the same time have promoted their preferred form of workforce reduction: temporary layoffs with promise of recall (Jung 2012). Even when unions have failed to prevent firms from adopting downsizing plans, they have attempted to exert influence over how they are implemented. As least for union members, who are protected by collective bargaining agreements, firms have 
typically negotiated with unions about the pace and terms of layoffs and other issues such as severance packages. Some unions have also directly challenged on-going downsizing. For instance, the strikes by United Auto Workers (UAW) at two General Motors parts factories significantly delayed the company's downsizing efforts (Bradsher 1998). Hence, I expect to find in my data that resistance from unions will hinder rapid and thorough implementation of adopted downsizing plans.

While union resistance may impede the overall pace of implementation, however, it may facilitate another aspect of implementation - the reduction in the relative proportion of managerial jobs. When pressured by firms to make concessions - such as work rule changes, wage cuts, and layoffs_-labor unions often call for similar sacrifice from white-collar workers. When steel companies, hurt by recessions and imports in the 1980s, pressured unionized workers to make concessions, the present of the United Steelworkers of America countered that the companies would have to institute reforms first, including reducing what he said were excessive layers of supervisors and other white-collar managers (Serrin 1986). And firms sometimes do increase white-collar job cuts in an apparent attempt to mollify their unionized workforce. After the eight-week strike over GM's downsizing plan, the company announced a sweeping reorganization, which included elimination of as many as 1,000 white-collar jobs (Krebs 1998). Hypothesis 2: Resistance from labor unions will delay the post-announcement reduction in the total number of employees, but will accelerate the post-announcement reduction in the proportion of managerial employees.

\subsubsection{Self-Interest of Top Managers}


The self-interest of managers is yet a third factor that determines the implementation of formally adopted policies. Even at the adoption stage, managers exert considerable influence over which policies are adopted and which are not. Dobbin and Jung (2012), for instance, show that although institutional investors have promoted a set of agency-theory prescriptions to maximize shareholder value, executives have embraced only those prescriptions that serve their own interest (e.g., stock option grants), while resisting others that might constrain their power (e.g., governance reforms). Given the influence of managers over the adoption of policies, even after a firm does adopt a certain policy, managerial influence, based on self-interest, will significantly determine the level of implementation (Westphal and Zajac 2001).

Under what circumstances, then, do managers come to have greater incentive to more fully implement adopted downsizing plans? One important factor is the structure of executive compensation. Studies have shown that equity-based compensation practices, which tie executive compensation to the performance of a given firm's stock, create strong incentives for managers to pursue strategies that maximize share price (Sanders 2001; Sanders and Hambrick 2007). Firms whose CEOs are paid mostly in stock options are, in fact, more likely to make downsizing announcements than firms whose CEOs are mostly paid in cash (Jung 2012). To the extent that implementation of announced downsizing plans enhances the firm's stock price, equity-based compensation may also facilitate its implementation.

Therefore, I expect that equity-compensated managers will facilitate the implementation of announced downsizing plans, thus leading to more rapid reductions in the overall employment level. They, however, may not be equally active in executing another aspect of the implementation - the reduction in managerial jobs. Despite the prevailing rhetoric against the bloated corporate bureaucracies of the 1990s, Gordon (1996) argues, the spread of workforce 
downsizing has failed to remove them; instead, it has increased the bureaucratic burden of supervising less-motivated workers, rather ironically fattening corporate bureaucracies. A recent study by Goldstein (2012) study, using industry level data, provides support for this argument; the prevalence of downsizing is positively correlated with the proportion of managerial workers and the valuation of managerial work.

Hypothesis 3: The self-interest of managers will accelerate the post-announcement reduction in the total number of employees but not the post-announcement reduction in the proportion of managerial employees.

\subsection{DATA AND METHOD}

I present fixed-effects models of the implementation of announced downsizing plans for the period 1984-2005. The fixed effects allow me to determine whether changes in independent variables are followed by changes in dependent variables. Hence, the main effect of downsizing announcements will test whether they actually lead to reductions in both total and managerial workforce. The interaction effects of downsizing announcements with other mediating factors will test whether and how external pressure from institutional investors, resistance from labor unions, and self-interests of managers affect the implementation of those announced downsizing plans.

\subsubsection{Sample}

The original sample included 789 large U.S. companies that were traded between 1965 and 2006 . The primary sampling frame is Fortune's list of America's largest firms. I and my collaborators in data collection stratified the sample by industry, selecting a roughly equal number of firms 
from 23 industries. ${ }^{7}$ The majority of industries (16 out of 23) were sampled exclusively from the Fortune Industrial 500, and the remainder were from specialized Fortune lists. For entertainment and health care, we used Dun \& Bradstreet's Million Dollar Directory for years before 1983, at which point Fortune began to cover these industries. Another important aspect of our sample is that, unlike most longitudinal studies of large firms that use samples drawn at the beginning, we sampled firms evenly across the entire observation period. This ensures that our sample is not biased toward successful firms in later years and includes firms in growing as well as declining industries. The final sample contained 789 firms. For the present study, I use data on 694 firms that were listed as companies between 1984 and 2005.

\subsubsection{Dependent Variables}

Two dependent variables are used to capture the actual implementation of announced downsizing plans. The first dependent variable is the percentage change in the total number of employees, which is calculated as follows:

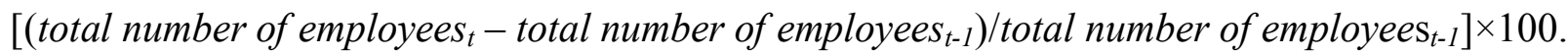

The second dependent variable is the log-odds of managerial employees, which measures the proportion of managerial employees relative to that of non-managerial employees. It is calculated as follows:

$\log \left(\text { proportion of managerial employees }_{t} / \text { proportion of non-managerial employees }\right)_{t}$.

\subsubsection{Independent Variables}

To construct an indicator variable for downsizing announcements, I collected information on the history of downsizing announcements for the sampled firms. Following Budros (1999), I define

\footnotetext{
${ }^{7}$ See Footnote 1.
} 
downsizing as permanent personnel reduction. This definition excludes announcements of temporary layoffs and sales of assets. Data on downsizing announcements were obtained through extensive archival search. The primary source was the Lexis/Nexis electronic database. The database catalogues most major newspapers, such as The Wall Street Journal and The New York Times, and several newswire services. Rather than limiting sources to one or two major newspapers - a tactic that previous studies have often adopted - I used all possible sources, including local newspapers. For each announcement, I read the contents carefully and dropped cases that referred to downsizing plans announced earlier. Using these data on downsizing announcements, I construct two binary variables, coded as one when there was a downsizing announcement by a given firm one year or two years, respectively, before a given year.

The indicator variables of downsizing announcements are interacted with variables measuring the influence of three interest groups - institutional investors, labor unions, and option-compensated executives - to examine how their influence affects the pace and the magnitude of the implementation of announced downsizing plans. First, pressure from institutional investors is measured by the percentage of a firm's stock owned by institutional investors, assuming that a firm will be under greater monitoring by these investors when a large portion of its shares is controlled by them. The information about ownership by institutional investors is from Thomson Financial's institutional ownership database.

Second, union resistance is measured by union membership at the industry level, assuming that firms in industries with high union membership will be more exposed to union resistance. The data on annual, industry-level union membership are provided by Hirsch and Macpherson (2003), via their website (http://www.unionstats.com). Their estimates are based on the Current Population Survey (CPS), using Bureau of Labor Statistics (BLS) methods. Because 
many firms have operations in more than one industry, I calculate a weighted average of union membership at industries in which a firm has operations. The weight for an industry is the portion of the firm's sales from that industry. This information is from Compustat's segment database.

Finally, the self-interest of managers are measured by the ratio of stock options to the CEO's total compensation, assuming that managers will have more incentive in implementing downsizing when a considerable portion of their compensation tied to their firms' stock market performance. Because Compustat's Execomp database, the primary source for executive compensation data, began in 1992 to report stock option values, which are calculated using the Black-Scholes-Merton method, I explore the effects of compensation in separate models, with a one-year lag, for only the period of 1993-2005. In addition to the ratio of stock options, I also include total CEO compensation as a control variable.

\subsubsection{Control Variables}

I include several control variables that may affect the change in employment size and the proportion of managerial workforce. Table 4.1 presents descriptive statistics. All variables included in the analyses vary annually and are lagged by one year so that they reflect the state in the previous fiscal year. First of all, several measures of firm performance and financial status are included. Cumulative stock returns (the change in share price over the previous 12 months) measure a firm's stock-market performance. Return on assets (ROA) is the most widely used measure of a firm's operating performance. Debt-to-equity ratio is included as a measure of a firm's financial leverage. 
Table 4.1: Data Sources and Descriptive Statistics

\begin{tabular}{lccc}
\hline \hline & Data Sources & Mean & S.D. \\
\hline \% Change in the Total Employment & Compustat & 1.423 & 18.819 \\
Log Odds of Managerial employees & EEO-1 Reports & -1.938 & 0.476 \\
Downsizing, $t$-1 & & 0.178 & 0.383 \\
Downsizing, $t$-2 & & 0.174 & 0.379 \\
Institutional Ownership & Thompson Financail & 49.617 & 22.357 \\
Labor Union Density & Unionstat.com & 19.320 & 13.909 \\
CEO Stock Options & Execomp & 0.320 & 0.267 \\
CEO Compensation & Execomp & 8.100 & 1.020 \\
Cumulative Stock Returns & CRSP & 0.190 & 0.548 \\
Return on Assets & Compustat & 2.732 & 22.904 \\
Debt-to-Equity Ratio & Compustat & 0.668 & 29.798 \\
Board Independence & S\&P Registers & 74.716 & 14.587 \\
Analyt Coverage & IBES & 2.308 & 0.864 \\
CEO=Chair & S\&P Registers & 0.696 & 0.460 \\
CEO Tenure & S\&P Registers & 1.687 & 0.980 \\
Chief Financial Officer & S\&P Registers & 0.622 & 0.485 \\
Diversification & Compustat & 0.427 & 0.491 \\
Acquisitions & SDC Platinum & 0.047 & 0.238 \\
Divestitures & SDC Platinum & 0.387 & 1.060 \\
PPE per Employee & Compustat & 3.980 & 1.311 \\
Employees & Compustat & 2.645 & 1.200 \\
Total Assets & Compustat & 7.564 & 1.596 \\
\hline
\end{tabular}


The presence of monitoring mechanisms other than the one by institutional investors may also reduce the chance that an announced downsizing plan is not under-implemented. As for internal monitoring, it is often assumed that the more independent directors are from management, the more effective the internal monitoring by the board of directors will be. Board independence is measured by the percentage of outside directors on the board. Outside directors are defined as any directors not employed by the firm. Monitoring by securities analysts provides another mechanism for external monitoring, which is measured by the number of securities analysts covering a firm. A firm is assumed to be under greater monitoring by these analysts when there are many analysts covering the firm. This variable is log-transformed to correct for its heavily right-skewed distribution.

To control for the influence of powerful CEOs over the implementation process, two measures of CEO power are also included (Westphal and Zajac 2001). A binary variable is used, which is coded one for firm-years when a firm's CEO is also the chair of the board. CEO tenure is the number of years the incumbent had held the position. The role of other high rank executives is considered by including a binary variable for chief financial officers (CFOs), a role which has recently been used to promote cost-saving measures such as downsizing (Jung 2012).

To control for the effects of restructuring events other than workforce downsizing, the number of acquisitions and divestitures, respectively, completed by a focal firm in the previous fiscal quarter is included. The extent to which a firm's operation is spread across multiple industries is captured by the entropy index of diversification (Palepu 1985). This variable is expected to have a positive effect on both the total number of employees and the proportion of managerial workforce. Investment in new technology is measured using a firm's net 
expenditures in property, plant, and equipment (PPE) per employee. A firm's workforce size is the total number of employees. Finally, firm size is measured as total assets.

\subsubsection{Missing Values and Multiple Imputation}

For some financial variables, missing values are of concern. The most severe case is the ROA variable; for about 15 percent of all quarterly intervals, this information is not available. For all other variables, the rate of missing data is less than 5 percent. Whenever the data are not missing completely at random, listwise deletion can yield biased estimates (Allison 2002). To address this problem, I estimated missing values for these variables using multiple imputation, using a multiple imputation program, Amelia II (King et al. 2001). Models are robust to the exclusion of organization-years for which there are missing data.

\subsubsection{Statistical Method}

I conduct pooled cross-sectional time series analyses of longitudinal data on both the percentage change in the total number of employees and the log-odds of managerial employees. The firm fixed effects account for unobserved characteristics that do not vary over time, such as industry and region. The year fixed effects account for those factors that affect all firms equally (such as macroeconomic conditions) but vary across time. Although this fixed-effects specification employs a large number of parameters and thus reduces model efficiency, it provides stringent tests of hypotheses about how changes in independent variables affect outcomes (Greene 2008). The specification also offers an efficient means of dealing with non-constant variance of the errors (heteroskedasticity) which derives from our use of multiple observations of each firm (Allison 2005). 


\subsection{RESULTS}

I present models exploring how firms implement their announced downsizing plans. The baseline models include all independent and control variables but do not have any interaction terms with the indicators of downsizing announcements. The main effects of downsizing announcements will reveal whether or not firms actually implement announced downsizing plans. I then add interaction terms of downsizing announcements with other independent variables and test whether and how these factors affect the pace of implementation. All models except for those with executive compensation variables (Models 4 and 5) cover the entire study period between 1984 and 2005. The models with compensation variables cover a sub-period between 1993 and 2005, because the variables are only available from 1993, with a one-year lag. Models

of the percentage change in the total number of employees are reported in Table 4.2, and those of the log-odds of managerial employees in Table 4.3. Figures 1 through 2 graphically illustrate the interaction effects of downsizing announcements and other explanatory variables.

\subsubsection{Main Effects of Downsizing Announcements}

To begin with the main effects of downsizing announcements, there is considerable evidence that firms actually implement their announced downsizing plans, but their implementation falls short in terms of reducing the proportion of non-productive workforce. Specifically, in Model 1 of Table 4.2, the coefficients of downsizing announcements suggest that a downsizing announcement, on average, leads to a reduction in total employment size of about 4 percent in 


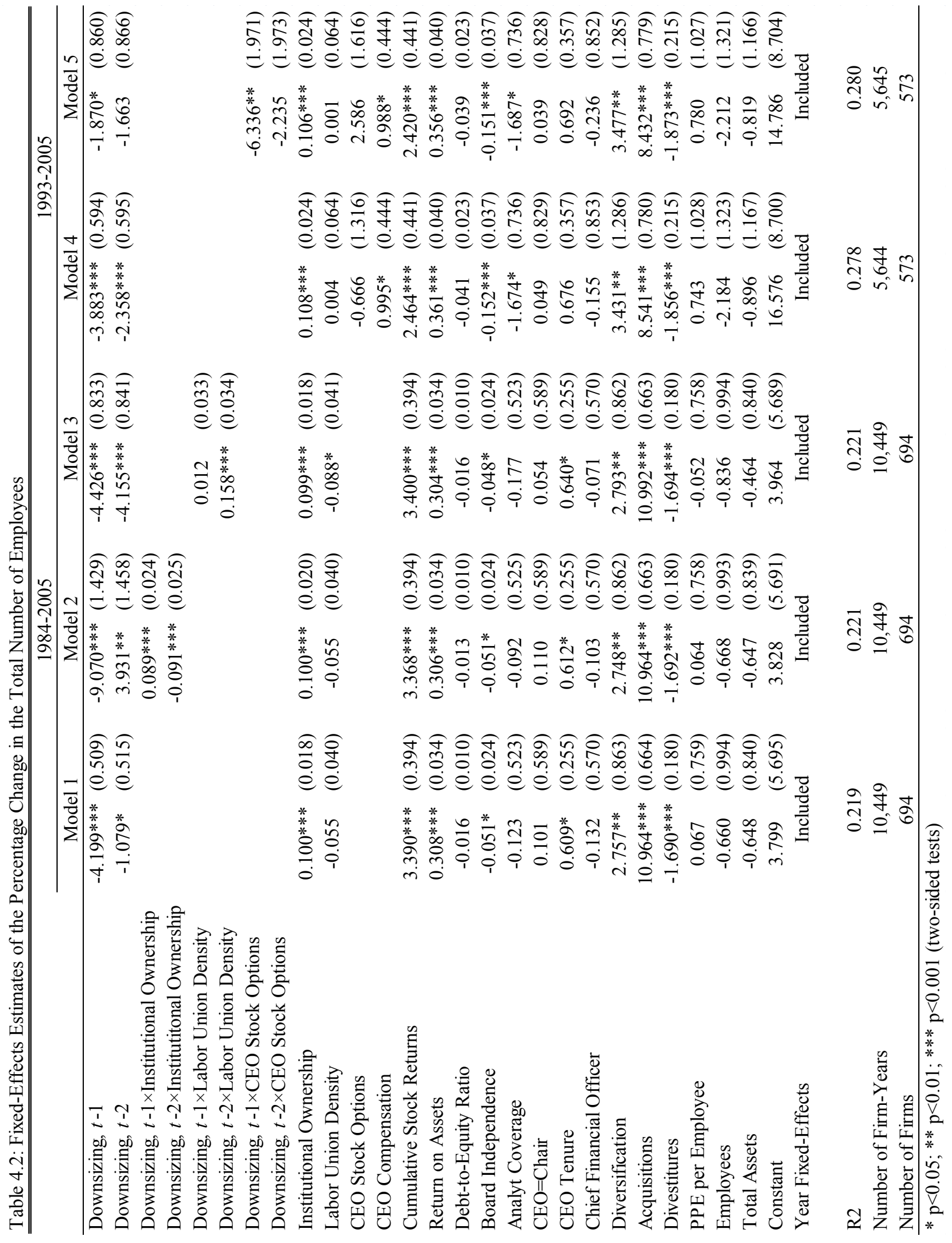




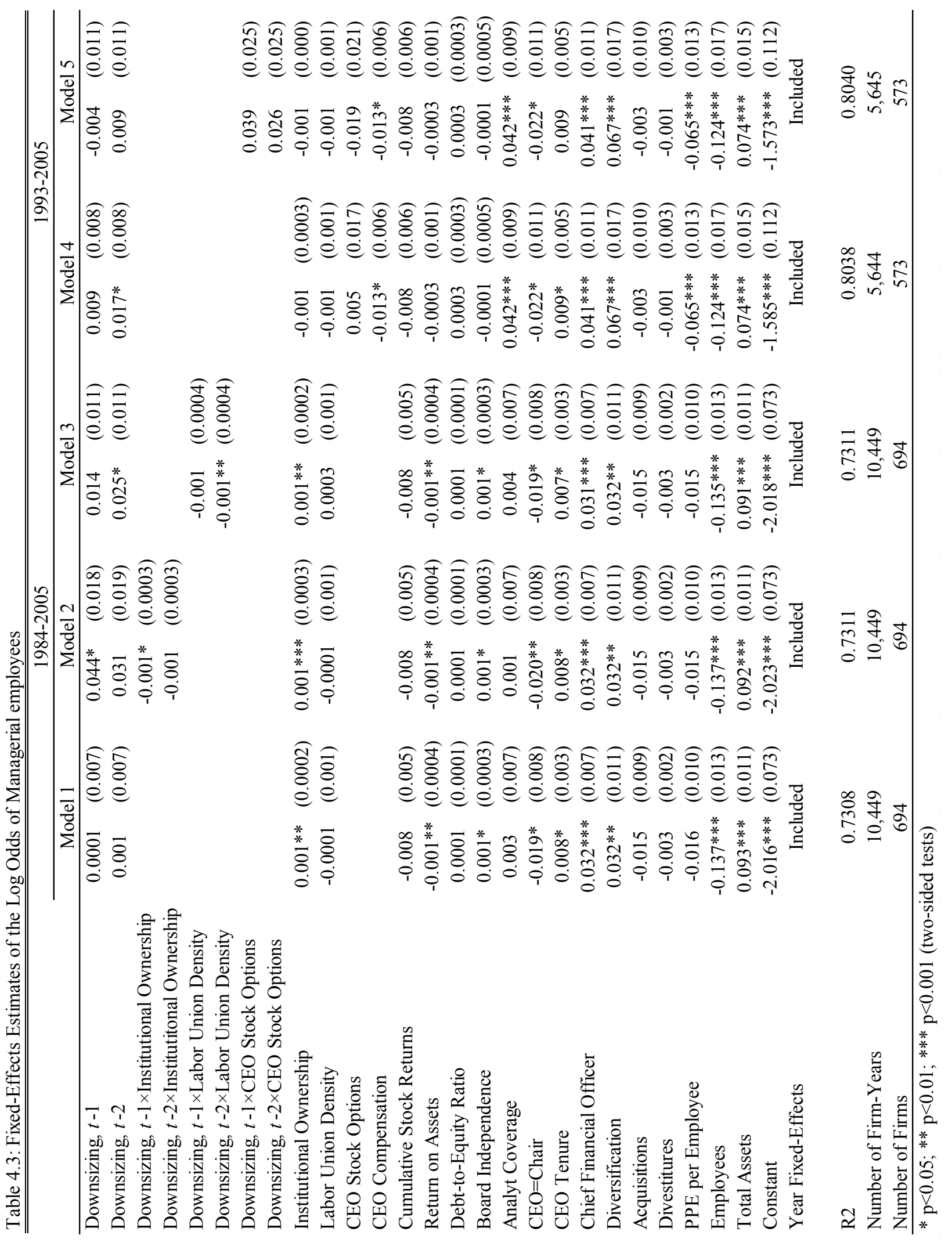


$\mathrm{s}$ the first year and a reduction of another one percent in the second year. These patterns remain more or less the same in the later period in Model 4, which replicate Model 1 with compensation variables for the period between 1993 and 2005, except that the magnitude of the reduction in the second is somewhat larger. Similar reductions are not observed, however, for the relative proportion of managerial employees; downsizing announcements do not lead to reduction in the relative proportion of those employees. In fact, there is some evidence in Model 4 of Table 4.3 that downsizing announcements lead to an increase in the relative proportion of managerial employees in the later period, which confirms the claim that the managerial workforce reemerged in the 1990s (Goldstein 2012).

\subsubsection{Interaction Effects}

I now turn to the interaction effects of downsizing announcements and other key explanatory variables. First, there is partial and somewhat mixed support for Hypothesis 1 that external pressure from institutional investors facilitates the implementation of announced downsizing plans. The evidence of their role in accelerating the post-announcement reduction in total employment size is mixed. The evidence of their role in another aspect of the implementationthe reduction in the relative proportion of managerial employees - is more consistent, but limitedly so in that they prevent firms from increasing the proportion of managerial employees but fall short of pushing firms to reduce the number. There is stronger support for both Hypotheses 2 and 3. Labor unions impede the first aspect of implementation but facilitate the second. Hence, once firms adopt a downsizing plan, labor unions attempt to lessen its impact and to ensure that managerial workers share some of the pain. In contrast, the self-interest of 
managers facilitates the first but not the second, suggesting that top managers are not willing to cut their own ranks.

To begin with Hypothesis 1, there is evidence that monitoring by institutional investors significantly affects the implementation of announced downsizing plans, but some of its effect is unexpected. Model 2 of Table 4.2 suggests that institutional ownership slows down, rather than accelerates, the post-announcement reduction in total employment size in the first year. This is can be seen in Figure 4.1: the reduction in total employment size is larger at lower levels of institutional ownership, but it becomes smaller at higher levels. In the second year after a downsizing announcement, however, institutional ownership accelerates the reduction. The pattern in Figure 4.1 shows that downsizing announcements lead to a reduction after two years only at high levels of institutional ownership. These patterns suggest that, although institutional ownership may not accelerate the pace of the post-announcement reduction initially, it prolongs the reduction. In addition, Model 2 of Table 4.3 suggests that institutional ownership pushes firms to cut deep into the managerial ranks. Downsizing announcements in the previous year lead to a reduction in the relative proportion of managerial employees only at high levels of institutional ownership (see the right graph of Figure 4.1). At very low levels, downsizing announcements actually lead to an increase in the relative proportion of managerial employees.

There is quite strong evidence to support Hypothesis 2 regarding resistance from labor unions. Model 3 of Table 4.2 suggests that, although their resistance does not impede the postannouncement reduction in the first year, it does do so in the second year. Hence in Figure 4.2, at very low levels of union membership, a downsizing announcement results in a 4 percent reduction in total employment size in the second year, but the magnitude of this reduction becomes smaller as union membership in the firm's industry increases. In addition, Model 3 of 

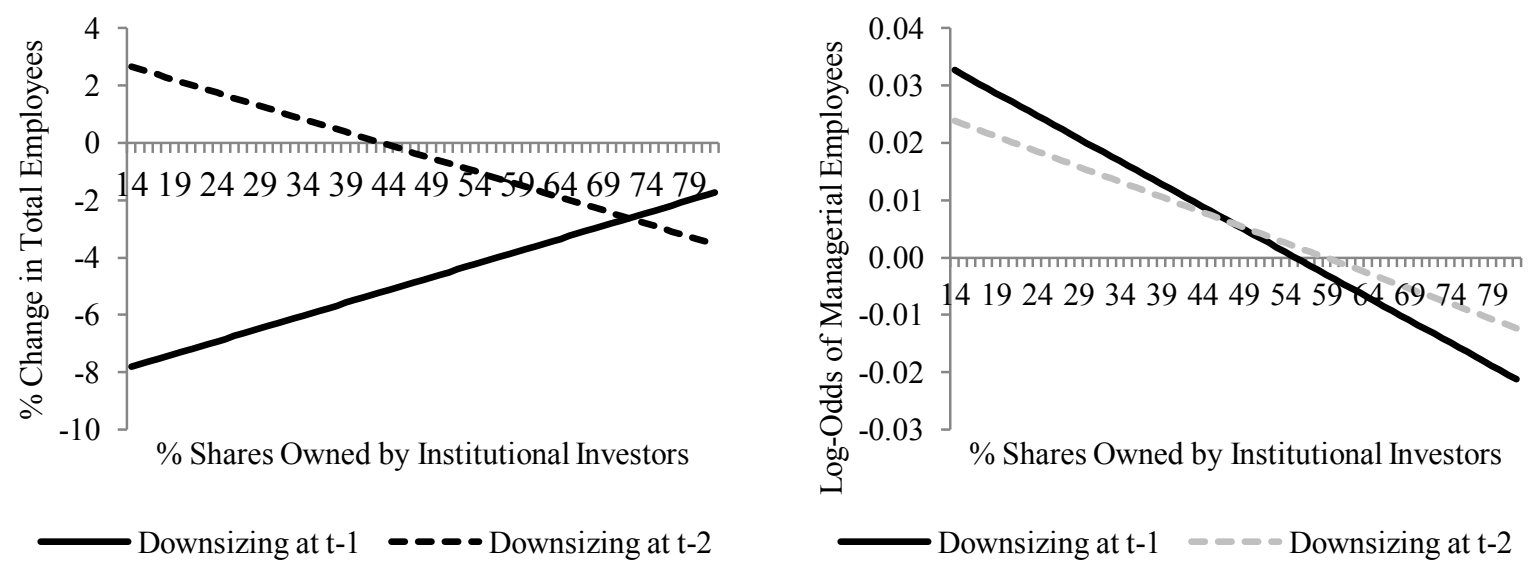

Figure 4.1: Interaction Effects with Institutional Ownership Note: Grey lines indicate statistically insignificant effects.

Table 4.3 suggests the strong presence of labor unions pushes firms to reduce the relative size of managerial ranks after downsizing announcements, particularly in the second year. As is shown in Figure 4.2, the relative proportion of managerial employees significantly increases at low levels of union membership in the second year after downsizing announcements, but this positive effect becomes significant reduced as union membership in the firm's industry increases.
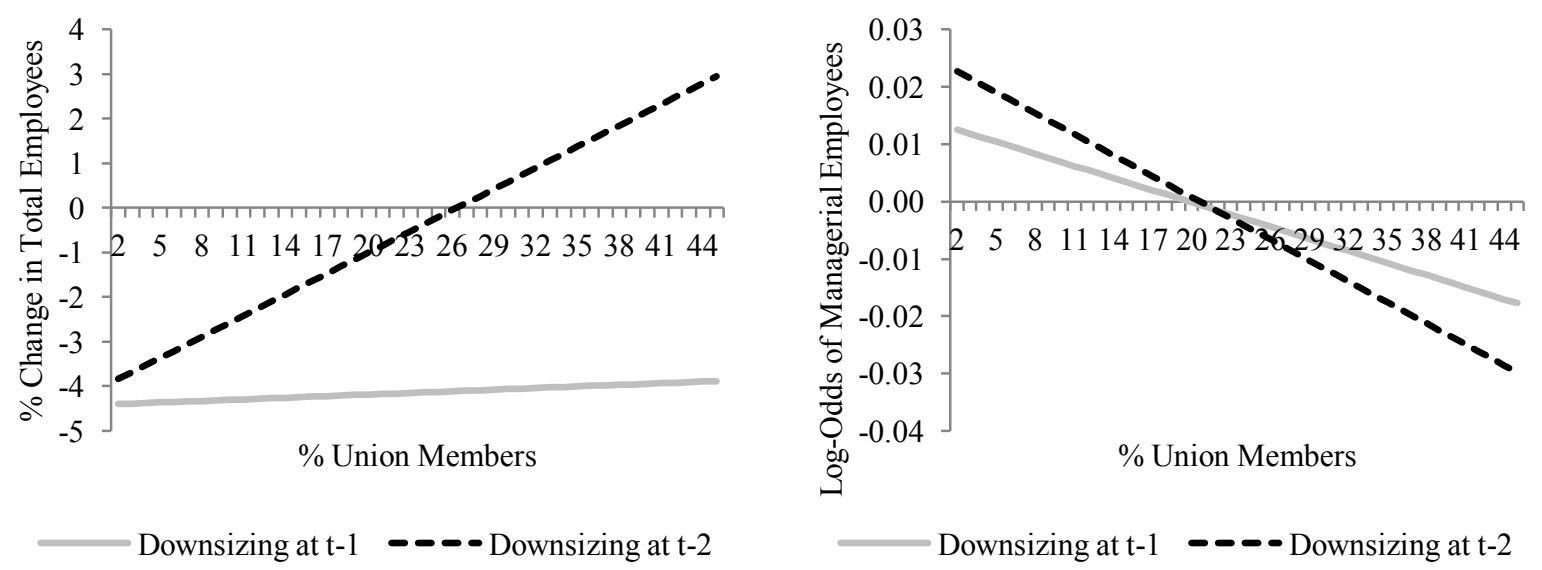

Figure 4.2: Interaction Effects with Union Density 
As predicted in Hypothesis 3, there is substantial evidence that managerial self-interests facilitate implementation, but their facilitating role is limited to reduction in total employment size. Model 5 of Table 4.2 provides strong evidence that CEOs whose compensation is predominantly equity-based are more willing to implement announced downsizing plans. As is shown in Figure 4.3, the magnitude of the first-year post-announcement reduction in total employment size is significantly dependent on the extent to which the CEO is paid in stock options. As its percentage increases from zero percent to 80 percent, the average magnitude of the reduction in the first year increases from 2 percent to 7 percent. Option-loaded CEOs, however, seem to have little incentive to reduce the relative size of the managerial workforce. In Model 5 of Table 4.3, the coefficient for the interaction term with stock options is positive but insignificant.
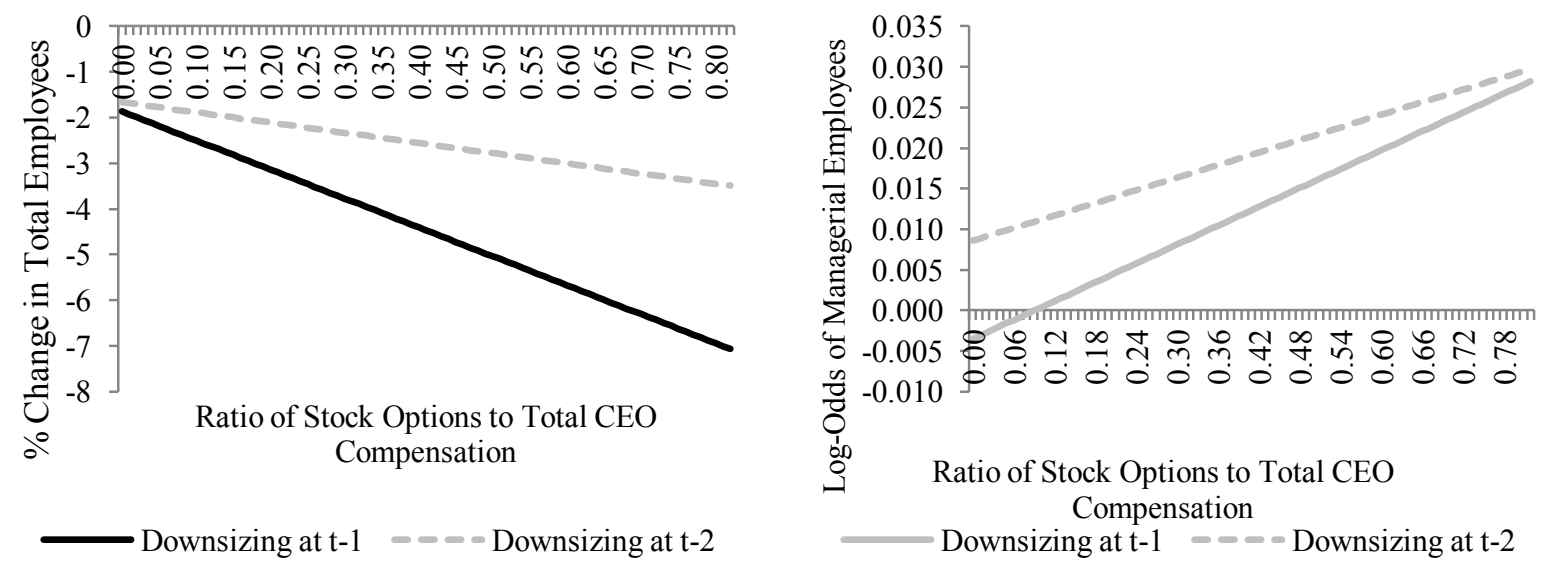

Figure 4.3: Interaction Effects with CEO Stock Options

\subsubsection{Control Variables}

All three measures of performance have a positive effect on the percentage change in the total number of employees, but their effect on the relative proportion of managerial employees is 
inconsistent: operating performance has a negative effect but stock market performance has no significant effect. There is some evidence of CEO power: firms with long-tenured CEOs tend to increase the total employment size and to have a higher proportion of managerial employees. Board independence decreases total employment size, but not the proportion of managerial employees. The effects of other restructuring events are also observed: as expected, acquisitions increase employment size, but divestitures reduce it. However, neither has any effect on the relative proportion of managerial employees. As for diversification, it leads to an increase in both total employment and the relative proportion of managerial workforce. Finally, large firms in terms of asset size have a larger proportion of managerial employees, but employment size has the opposite effect.

\subsection{CONCLUSION}

Since the 1980s, leading U.S. firms have announced massive downsizing plans as a means of enhancing shareholder value. But the effectiveness of this strategy should depend on whether and how firms implement their announced downsizing plans. In this respect, there has been a suspicion that firms make the move in order to impress the financial community, but with little intention to fully implement those dazzling downsizing plans. One might take this as a classical example of decoupling where firms adopt a certain policy or practice as a gesture of conforming to institutional demands but do not implement them because they wish to maintain their internal status quo (Meyer and Rowan 1977). The alleged intention of firms to shape positive market reactions with massive downsizing plans even suggests that firms strategically engage in decoupling to actively manage their institutional environment (Boxenbaum and Jonsson 2008; Westphal and Zajac 1998; Westphal and Zajac 2001). 
In this paper, I provide an alternative to this strategic perspective on decoupling. I argue that a lack of implementation does not necessarily indicate a given firm's attempt to decouple adoption from implementation. Instead, I propose a socio-political account of policy implementation in which the extent to which a formally-adopted policy is actually implemented crucially depends on the political dynamics among groups, both inside and outside of the firm, with conflicting interests. From this perspective, a lack of implementation may reflect the political tension among such groups over the implementation of the adopted policy. My analysis of the implementation of announced downsizing plans by 694 leading U.S. firms between 1984 and 2005 provides ample evidence to support my socio-political account of policy implementation. Specifically, I examine the role of three competing interest groups (institutional investors, labor unions, and corporate managers) and show that these interest groups have contrasting influences over two different aspects of implementation—post-announcement reduction in overall employment size and reduction in the relative proportion of managerial employees.

In general, my analysis of the implementation of announced downsizing plans suggests that there exists considerable variation in the extent to which a formally-adopted policy is implemented, and that a significant portion of such variation in policy implementation can be explained by the political dynamics among interest groups in and around the firm. These findings have a number of theoretical implications for the literature of organizational institutionalism. The first important implication is that the implementation phase should be studied as a crucial component of the process of institutional change. Since DiMaggio and Powell (1983), organizational institutionalists have done extensive research on the adoption or the diffusion of formal structures or policies. In some cases, formal adoption of new policies may be indicative 
of substantive institutional change. But in other cases, what seems more important is whether and how formally-adopted policies are implemented. That organizations adopt a policy is surely some kind of institutional change, especially when the adoption is driven by a new institutional demand, but, if the adopted policy is not seriously implemented, it seems hard to claim that the diffusion of the policy leads to substantive institutional change.

Given the importance of implementation as a crucial part of any substantive institutional change, my findings of the contrasting roles of competing interest groups demonstrates that implementation can be a highly contested process. In short, three interest groups-institutional investors, labor unions, and corporate managers-have conflicting interests in the implementation of downsizing and thus have contrasting influences over the process. Previous studies on the implementation of globally-diffused policies suggest that implementing such policies is often plagued by local resistance (Hafner-Burton and Tsutsui 2005; Halliday and Carruthers 2009; Weber et al. 2009; Zelner, Henisz, and Holburn 2009). The present study shows that a similar political tension exists over policy implementation at the organizational level. Moreover, it shows the role of some groups in facilitating implementation as well as the role of others in impeding implementation. The presence of powerful interest groups can not only impede but also facilitate institutional change, with the ultimate outcome being determined by the overall balance of power among groups. Hence, researchers of institutional change should pay more attention to the constellations of power, especially at the implementation stage.

By demonstrating the conflicting influences of different interest groups over implementation, the present study suggests that there exist limits on the ability of organizations to strategically manage institutional demands. Recent theoretical developments in institutional theory suggest that the availability of competing institutional models of action creates latitude for 
organizations to exercise some level of strategic choice (Clemens and Cook 1999; Dorado 2005; Seo and Creed 2002; Stryker 2000). Decoupling is one example. It is suggested that decoupling is a common organizational tactic for dealing with multiple, and often contradictory, institutional pressures on the organization (Boxenbaum and Jonsson 2008). My findings, however, suggest the opposite: multiple institutional demands constrain, rather than enhance, an organization's ability to advance its strategic goals. From this perspective, what seems like a case of decoupling actually reflects an organization's inability to implement reforms. A lack of implementation may indicate the presence of strong resistance from some powerful interest groups, rather than the firm's attempt to decouple. But at the same time, thorough implementation may indicate stringent monitoring and pressuring by other groups, rather than passive acquiescence by the firm. Again, whether multiple institutional demands enhance or constrain organizational autonomy should critically depend on the constellations of power. For instance, when a power struggle among interest groups results in some kind of gridlock and the same time organizations are under weak leadership, their ability to act can be severely undermined, leading to organizational paralysis (Pache and Santos 2010).

More broadly, my findings reiterate a common theme in the sociology of the firm; that is, firms are embedded in a dense network of power relations that extends beyond the immediate boundaries of the firm (Friedland and Alford 1991; Granovetter 1985). Previous studies demonstrate how the relationship between firms and other social and political entities, such as the government, and the power dynamics among the latter shape the behavior of firms (Dobbin and Dowd 2000; Fligstein 1990; King and Pearce 2010; Mintz and Schwartz 1985; Roy 1997). My findings of the contrasting roles of multiple interest groups over the implementation of downsizing resonate well with these previous studies. They demonstrate how being embedded in 
a web of power relations can limit as well as enhance a firm's ability to act strategically. In addition, my findings also demonstrate the prominent role of class dynamics in the process. Most recent studies have neglected the role of labor unions in explaining firm behavior. This might be justifiable given the steady decline in the power of unions over the past several decades, but my findings of the role of unions suggest that workers' voices should not be neglected especially when it comes to critical decisions on employment, of which implementation of downsizing is the prime example. 


\section{CONCLUSION}

In The Great Transformation, Karl Polanyi saw two opposing movements inherent in modern market societies; the laissez-faire movement to expand the scope of the market, and the protective countermovement that emerges to resist the disembedding of the economy (Block 2003). This tension has unfolded in the realm of finance in the U.S. since the Great Depression, culminating very recently in a serious financial crash. In response to the Great Depression, American law and politics, with the support of the New Deal coalition-a coalition of labor, small business owners, and farmers-deliberately diminished the power of financial institutions (Roe 1994). Regulations enacted during the New Deal Era—such as the Glass-Steagall Act and the Investment Company Act of 1940 — fragmented finance and did not allow financial institutions to become powerful enough to gain control of firms. Since the 1980s, however, the situation changed drastically. Deregulation during the Reagan Administration and afterwards removed most of the regulations on financial institutions originating from the New Deal era. Empowered by this new economic and political environment, financial institutions have increased their influence over the operation of firms under the banner of the "shareholder value" revolution (Davis 2009; Dobbin and Zorn 2005; Fligstein 2001; Useem 1996).

In this dissertation, I have examined how this rise of the shareholder-value paradigm and the growing influence of financial markets over firms since the 1980s have changed the employment practices of major U.S. firms, particularly on the case of workforce downsizings.

Previously, downsizing occurred primarily in times of economic downturn. Recently, firms have tended to cut jobs in both good and bad times, in order to boost financial performance (Appelbaum and Batt 1994; Cappelli 1999; Osterman 1999). The hegemony of the shareholder- 
value paradigm is evident in the prevalence of downsizing, especially given the lack of evidence that downsizing actually improves corporate performance. To be sure, downsizing can help firms to turn around declining performance by reducing labor costs, but most empirical studies document that downsizing is unlikely to lead to substantial savings and better performance. Nevertheless, there is a strong sense of taken-for-grantedness, not only among managers who conduct downsizing but also among workers who suffer from it, of the idea that downsizing is a painful but essential measure for the survival of firms and even of the overall economy.

Early work by institutionalists sees taken-for-grantedness as the driving force behind the diffusion of new practices. This appears to be the case with the prevalence of downsizing during the recent decades. For instance, Budros (1997, p. 233) claims that as more firms engaged in downsizing throughout the 1980s, it came to be viewed as "a common-sense way of managing." In a sense, there is much truth to this kind of claim. Louis Uchitelle (2006), the author of The Disposable American, probably the most profound critique of downsizing ever written, admits that it was hard even for him to overcome the notion that downsizing is "an unfortunate necessity" for revitalizing corporate America. Even today, this sense of inevitability seems to prevail. During the great recession in the aftermath of the financial crisis in 2008, many U.S. firms cut jobs on a massive scale. On a single day, January 26, 2009, when the newly-elected government was pushing for a $\$ 787$ billion stimulus bill designed to create or save 3.5 million jobs, five prominent U.S. firms - Caterpillar, Home Depot, Pfizer, Sprint, and Wyeth—announced their plan to eliminate a total of 55,000 jobs. The sheer size of downsizings announced by these firms made big news, but no specific action to prevent or even minimize their harmful impact was taken. The fact that massive downsizings arouse little opposition suggests that they have become objectified as a standard management practice (Suchman 1995). 
In this dissertation, I have taken issue with this widespread notion of downsizing as something unavoidable. To do so, I have investigated the power dynamics underneath the seemingly widespread social acceptance of downsizing. My investigation is informed by two significant recent developments in the literature of organizational institutionalism. One is the institutional approach to power (Davis, Diekmann, and Tinsley 1994; Dobbin and Dowd 2000; Fligstein 1990; Roy 1997). This approach combines the insights from institutional theory with those from power theory. The approach emphasizes the importance of interest-group politics in the process of institutionalization. In many important ways, it brings back in the initial insight of Karl Marx in his masterpiece The German Ideology, that the dominant ideology in each historical period reflects the prevailing mode of production and distribution of the period. The other significant development is institutional pluralism (Friedland and Alford 1991; Greenwood and Suddaby 2006; Marquis and Lounsbury 2007; Seo and Creed 2002). This approach posits that there exists in most situations more than one institutional logic, and that the dominance of the prevailing logic over others is often temporary and unstable. The significance of this approach is that it sensitizes researchers to the fact that the way things are today is not necessarily the only way that things should be, but rather one of many possible outcomes of the contest among, or the combination of, competing logics.

Building on and combining these two new developments in institutional theory, I have proposed a socio-political account of the new use of downsizing as a strategy of maximizing shareholder value. In three separate but closely related empirical chapters, I have described the role of three key interest groups - investors, managers, and workers—who promoted sometimes complementary but sometimes conflicting institutional logics about the firm-employee relationship. In the first chapter, I have shown that the prevalence of downsizing since the 1980s 
reflects the interest of institutional investors, who have been the most avid proponents of the shareholder-value paradigm, and the interest of managers, who benefit from pursuing shareholder-value maximization. In the second chapter, I have explored the contest between competing models of the firm-employee relationship — the shareholder-value model and industrial unionism, respectively—over the legitimate form of downsizing, by analyzing how labor unions attempted to maintain temporary layoff while protesting permanent layoff but mostly failed in both fronts. In the last chapter, I have documented the lingering class politics around the legitimacy of downsizing, by showing the contrasting roles of investors, managers, and unions in the implementation of announced downsizing plans. Together, these three chapters illustrate the class politics simmering under the surface of the acceptance of downsizing for shareholder-value maximization.

While this dissertation has focused on firm-level processes that have led to a new form of downsizing, many of the findings have broader social implications. By focusing on the prevalence and new form of workforce downsizing, I have explored firm-level causes of the precariousness of the U.S. labor market. The growing popularity of downsizing as a strategy for managing profits and share price has put a heavy burden on ordinary working- and middle-class Americans. Those who lose jobs as a result of plant closings or large-scale layoffs find it hard to find another job (Osterman 1999, p. 80-82), and their jobs are often replaced with temporary or part-time jobs (Kalleberg, Reskin, and Hudson 2000). Field studies of layoff survivors show that layoffs hurt morale in the workplace and generate a sense of injustice (Brockner et al. 1987; Brockner et al. 1994). This is not surprising when even high performers downsize to generate more profits. Proponents of workplace innovations contend that by undermining the basis of mutual trust between firms and their employees, layoffs hamper efforts to introduce workplace 
innovations, such as high-performance work organizations (Appelbaum and Batt 1994; Osterman 2000). By demonstrating how the shareholder-value paradigm has increased the precariousness of the U.S. labor market, this dissertation takes an important first step toward a synthesis between the organizational literature on firm behavior and the labor-market literature on the precariousness of work.

Turning to the future, how long will the trend in downsizing continue? To be sure, the hegemony of the shareholder-value paradigm has been significantly impaired in the aftermath of the recent collapse of the global financial system, but this has not yet led to a serious discussion of how to reform the firm-employee relationship in response to the severe hardship caused by the collapse. Rather, as I have mentioned above, firms have continued to shed jobs in order to maintain profitability and stock price. By squeezing more from a smaller number of workers, many firms have quickly rebounded, and some have even reported record profits. This corporate response to the recession suggests that the myth of downsizing as an inevitable necessity will continue at least in the near future. At the same time, however, the continuation of massive downsizing in the middle of a recession, and the persistence of high unemployment that lags behind the pace of economic recovery, may push the issue of employment—not only the quantity but also the quality of jobs - to the forefront of public discussion. Future work will need to trace whether and how this increased attention will reshape the class politics around downsizing and lead to a new model of the firm-employee relationship in the later 21 st century. 


\section{BIBLIOGRAPHY}

Ahmadjian, Christina L. and Gregory E. Robbins. 2005. "A Clash of Capitalisms: Foreign Shareholders and Corporate Restructuring in 1990s Japan." American Sociological Review 70:451-471.

Allison, Paul D. 1995. Survival Analysis Using SAS: A Practical Guide. Cary, NC: SAS Institute.

—. 1996. "Fixed-Effects Partial Likelihood for Repeated Events." Sociological Methods \& Research 25:207-222.

—. 2002. Missing Data. Thousand Oaks, CA: Sage Publications.

—. 2005. Fixed Effects Regression Methods for Longitudinal Data Using SAS. Cary, N.C.: SAS Press.

Amihud, Yakov and Baruch Lev. 1981. "Risk Reduction as a Managerial Motive for Conglomerate Mergers." Bell Journal of Economics 12:605-617.

Appelbaum, Eileen and Rosemary Batt. 1994. The New American Workplace: Transforming Work Systems in the United States. Ithaca: Cornell University Press.

Barley, Stephen R. and Kunda Gideon. 1992. "Design and Devotion: Surges of Rational and Normative Ideologies of Control in Managerial Discourse." Administrative Science Quarterly 37:363-399.

Barnett, William P. and Michael Woywode. 2004. "From Red Vienna to the Anschluss: Ideological Competition among Viennese Newspapers during the Rise of National Socialism." American Journal of Sociology 109:1452-1499. 
Baron, James N., Frank Dobbin, and P. Devereaux Jennings. 1986. "War and Peace: The Evolution of Modern Personnel Administration in U.S. Industry." American Journal of Sociology 92:350-383.

Basu, Onker N., Mark W. Dirsmith, and Parveen P. Gupta. 1999. "The Coupling of the Symbolic and the Technical in an Institutionalized Context: The Negotiated Order of the GAO's Audit Reporting Process." American Sociological Review 64:506-526.

Batt, Rosemary and Eileen Appelbaum. 2010. "Globalization, New Financial Actors, and Institutional Change: Reflections on the Legacy of LEST." in Travail, Emploi et Competence dans la Mondialisation. LEST, Universite de la Mediterranee.

Baum, Joel A. C. and Christine Oliver. 1991. "Institutional Linkages and Organizational Mortality." Administrative Science Quarterly 36:187-218.

—. 1992. "Institutional Embeddedness and the Dynamics of Organizational Populations." American Sociological Review 57:540-559.

Baumol, William J., Alan S. Blinder, and Edward N. Wolff. 2003. Downsizing in America. New York: Russell Sage Foundation.

Bendix, Reinhard. 1956. Work and Authority in Industry: Ideologies of Management in the Course of Institutionalization. New York: John Wiley and Sons.

Berger, Philip G. and Eli Ofek. 1995. "Diversification's Effect on Firm Value." Journal of Financial Economics 37:39-65.

Berle, Adolf A. and Gardiner C. Means. 1933. The Modern Corporation and Private Property. New York: Macmilan.

Bhagat, Sanjai and Bernard S. Black. 1999. "The Uncertain Relationship between Board Composition and Firm Performance." Business Lawyer 54:921-963. 
Bhagat, Sanjai, Andrei Shleifer, and Robert W. Vishny. 1990. "Hostile Takeovers in the 1980s:

The Return to Corporate Specialization." Brookings Papers on Economic Activity: Microeconomics:1-84.

Block, Fred. 2003. "Karl Polanyi and the Writing of The Great Transformation." Theory and Society 32:275-306.

Bluestone, Barry and Bennett Harrison. 1982. The Deindustrialization of America: Plant Closings, Community Abandonment, and the Dismantling of Basic Industry. New York: Basic Books.

Blyth, Mark. 2002. Great Transformations: Economic Ideas and Institutional Change in the Twentieth Century. New York: Cambridge University Press.

Box-Steffensmeier, Janet M. and Bradford S. Jones. 2004. Event History Modeling: A Guide for Social Scientists. Cambridge: Cambridge University Press.

Boxenbaum, Eva and Stefan Jonsson. 2008. "Isomorphism, Diffusion and Decoupling." Pp. 7898 in The SAGE Handbook of Organizational Institutionalism, edited by R. Greenwood, C. Oliver, K. Sahlin, and R. Suddaby. Thousand Oaks, CA: SAGE.

Bradsher, Keith. 1998. "Money and Other Hardening Positions in Strikes at G.M." Pp. 1 in New York Times. New York.

Brickley, James A., Ronald C. Lease, and Clifford W. Smith, Jr. 1988. "Ownership Structure and Voting on Antitakeover Amendments." Journal of Financial Economics 20:267-291.

Budros, Art. 1997. "The New Capitalism and Organizational Rationality: The Adoption of Downsizing Programs, 1979-1994." Social Forces 76:229-249.

—. 1999. "A Conceptual Framework for Analyzing Why Organizations Downsize." Organization Science 10:69-82. 
—. 2000. "Organizational Types and Organizational Innovation: Downsizing Among Industrial, Financial, and Utility Firms." Sociological Forum 15:273-306.

—. 2002. "The Mean and Lean Firm and Downsizing: Causes of Involuntary and Voluntary Downsizing Strategies." Sociological Forum 17:307-342.

Burns, Natasha and Simi Kedia. 2006. "The Impact of Performance-Based Compensation on Misreporting." Journal of Financial Economics 79:35-67.

Callon, Michel. 1998. "The Laws of the Markets." Oxford: Blackwell.

Campbell, John L. 2004. Institutional Change and Globalization. Princeton, NJ: Princeton University Press.

Campbell, John L. and Leon N. Lindberg. 1990. "Property Rights and the Organization of Economic Activity by the State." American Sociological Review 55:634-647.

Cappelli, Peter. 1999. The New Deal at Work: Managing the Market-Driven Workforce. Boston: Harvard Business School Press.

Carleton, Willard T., James M. Nelson, and Michael S. Weisbach. 1998. "The Influence of Institutions on Corporate Governance through Private Negotiations: Evidence from TIAA-CREF." Journal of Finance 53:1335-1362.

Cascio, Wayne F., Clifford E. Young, and James R. Morris. 1997. "Financial Consequences of Employment-Change Decisions in Major U.S. Corporations." Academy of Management Journal 40:1175-1189.

Causey, Mike. 1985. "Layoff Rules Debated." in Washington Post. Washington, DC.

Caves, Richard E. and Matthew B. Krepps. 1993. "Fat: The Displacement of Nonproduction Workers from U.S. Manufacturing Industries." Brookings Papers on Economic Activity: Microeconomics 2:227-288. 
Clary, Isabelle. 1991. "IBM to reduce international staff by 14,000." in United Press International. New York.

Clawson, Dan and Mary Ann Clawson. 1999. "What Has Happened to the US Labor Movement? Union Decline and Renewal." Annual Review of Sociology 25:95.

Clemens, Elisabeth S. and James M. Cook. 1999. "Politics and Institutionalism: Explaining Durability and Change." Annual Review of Sociology 25:441-466.

Coffee, John C., Jr. 1991. "Liquidity versus Control: The Institutional Investor as Corporate Monitor." Columbia Law Review 91:1277-1368.

Comment, Robert and Gregg A. Jarrell. 1995. "Corporate Focus and Stock Returns." Journal of Finacial Economics 37:67-87.

Cooke, William N. and David G. Meyer. 1990. "Structural and Market Predictors of Corporate Labor Relations Strategies." Industrial and Labor Relations Review 43:280-293.

Coy, Peter. 1986. "IBM Announces Early-Retirement Incentives; Analysts Pleased." in The Associated Press. New York.

Dalton, Dan R., Catherine M. Daily, S. Trevis Certo, and Rungpen Roengpitya. 2003. "MetaAnalyses of Financial Performance and Equity: Fusion or Confusion?" Academy of Management Journal 46:13-26.

Datta, Deepak K., James P. Guthrie, Dynah Basuil, and Alankrita Pandey. 2010. "Causes and Effects of Employee Downsizing: A Review and Synthesis." Journal of Management $36: 281-348$

David, Parthiban, Rahul Kochhar, and Edward Levitas. 1998. "The Effect of Institutional Investors on the Level and Mix of CEO Compensation." Academy of Management Journal 41:200-208. 
Davis, Gerald F. 2005. "New Directions in Corporate Governance." Annual Review of Sociology $31: 143-162$.

—. 2008. "A New Finance Capitalism? Mutual Funds and Ownership Re-concentration in the United States." European Management Review 5:11-21.

—. 2009. Managed by the Markets: How Finance Reshaped America. New York: Oxford University Press.

Davis, Gerald F., Kristina A. Diekmann, and Catherine H. Tinsley. 1994. "The Decline and Fall of the Conglamerate Firm in the 1980s: The Deinstitutionalization of an Organizational Form." American Sociological Review 59:547-570.

Davis, Gerald F. and E. Han Kim. 2007. "Business Ties and Proxy Voting by Mutual Funds." Journal of Financial Economics 85:552-570.

Davis, Gerald F. and Mark S. Mizruchi. 1999. "The Money Center Cannot Hold: Commercial Banks in the U.S. System of Corporate Governance." Administrative Science Quarterly 44:215-239.

Davis, Gerald F. and Tracy A. Thompson. 1994. "A Social Movement Perspective on Corporate Control." Administrative Science Quarterly 39:141-173.

De Meuse, Kenneth P., Paul A. Vanderheiden, and Thomas J. Bergmann. 1994. "Announced Layoffs: Their Effect on Corporate Financial Performance." Human Resource Management 33:509-530.

Del Guercio, Diane and Jennifer Hawkins. 1999. "The Motivation and Impact of Pension Fund Activism." Journal of Financial Economics 52:293-340. 
DiMaggio, Paul J. 1988. "Interest and Agency in Institutional Theory." Pp. 3-21 in Institutional Patterns and Organizations: Culture and Environment, edited by L. G. Zucker. Cambridge, MA: Ballinger.

DiMaggio, Paul J. and Walter W. Powell. 1983. "The Iron Cage Revisited: Institutional Isomorphism and Collective Rationality in Organizational Fields." American Sociological Review 48:147-160.

Dobbin, Frank and Timothy J. Dowd. 1997. "How Policy Shapes Competition: Early Railroad Foundings in Massachusetts." Administrative Science Quarterly 42:501-529.

—. 2000. "The Market That Antitrust Built: Public Policy, Private Coercion and Railroad Acquisitions, 1825 to 1922." American Sociological Review 65:631-657.

Dobbin, Frank and Jiwook Jung. 2010. "The Misapplication of Mr. Michael Jensen: How Agency Theory Brought Down the Economy and Why it Might Again." in Research in the Sociology of Organizations, vol. 30, edited by M. Lounsbury and P. M. Hirsch. Bingley, UK: Emerald.

—. 2012. "The Fund Manager-Value Revolution: How Institutional Investors Hijacked Shareholder Value." Cambridge, MA: Harvard University.

Dobbin, Frank and John R. Sutton. 1998. "The Strength of a Weak State: The Rights Revolution and the Rise of Human Resources Management Divisions." American Journal of Sociology 104:441-476.

Dobbin, Frank, John R. Sutton, John W. Meyer, and Richard Scott. 1993. "Equal Opportunity Law and the Construction of Internal Labor Markets." American Journal of Sociology 99:396-427. 
Dobbin, Frank and Dirk M. Zorn. 2005. "Corporate Malfeasance and the Myth of Shareholder Value." Political Power and Social Theory 17:179-198.

Dorado, Silvia. 2005. "Institutional Entrepreneurship, Partaking, and Convening." Organization Studies 26:385-414.

Dore, Ronald P. 1973. British Factory, Japanese Factory: The Origins of National Diversity in Industrial Relations. Berkeley, CA: University of California Press.

Dougherty, Deborah and Edward H. Bowman. 1995. "The Effects of Organizational Downsizing on Product Innovation." California Management Review 37:28-44.

Dunn, Mary B. and Candace Jones. 2010. "Institutional Logics and Institutional Pluralism: The Contestation of Care and Science Logics in Medical Education, 1967--2005." Administrative Science Quarterly 55:114-149.

Edelman, Lauren. 1990. "Legal Environments and Organizational Governance: The Expansion of Due Process in the American Workplace." American Journal of Sociology 95:14011440.

—. 1992. "Legal Ambiguity and Symbolic Structures: Organizational Mediation of Civil Rights Law." American Journal of Sociology 97:1531-1576.

Efendi, Jap, Anup Srivastava, and Edward P. Swanson. 2007. "Why Do Corporate Managers Misstate Financial Statements? The Role of Option Compensation and Other Factors." Journal of Financial Economics 85:667-708.

Efron, Bradley. 1977. "The Efficiency of Cox's Likelihood Function for Censored Data." Journal of the American Statistical Association 72:557-565. 
Elsbach, Kimberly D. 1994. "Managing Organizational Legitimacy in the California Cattle Industry: The Construction and Effectiveness of Verbal Accounts." Administrative Science Quarterly 39:57-88.

Elsbach, Kimberly D. and Robert I. Sutton. 1992. "Acquiring Organizational Legitimacy through Illegitimate Actions: A Marriage of Institutional and Impression Management Theories." Academy of Management Journal 35:699-738.

Emerson, Richard M. 1962. "Power-Dependence Relations." American Sociological Review $27: 31-41$

Fama, Eugene F. 1980. "Agency Problems and the Theory of the Firm." Journal of Political Economy 88:288-307.

Farber, Henry S. and Bruce Western. 2002. "Ronald Reagan and the Politics of Declining Union Organization." British Journal of Industrial Relations 40:385-401.

Feldstein, Martin. 1976. "Temporary Layoffs in the Theory of Unemployment." Journal of Political Economy 84:937-957.

Fernandez, Roberto M. 2001. "Skill-Based Technological Change and Wage Inequality: Evidence from a Plant Retooling." American Journal of Sociology 107:273-320.

Fiss, Peer C. and Edward J. Zajac. 2004. "The Diffusion of Ideas over Contested Terrain: The (Non)adoption of a Shareholder Value Orientation among German Firms." Administrative Science Quarterly 49:501-534.

Flanagan, David J. and K. C. O’Shaughnessy. 2005. "The Effect of Layoffs on Firm Reputation." Journal of Management 31:445-463.

Fligstein, Neil. 1985. "The Spread of the Multidivisional Form Among Large Firms, 19191979." American Sociological Review 50:377-391. 
—. 1987. "The Intraorganizational Power Struggle: Rise of Finance Personnel to Top Leadership in Large Corporations, 1919-1979." American Sociological Review 52:44-58.

—. 1990. The Transformation of Corporate Control. Cambridge, MA: Harvard University Press.

—. 1996. "Markets as Politics: A Political-Cultural Approach to Market Institutions." American Sociological Review 61:656-673.

—. 2001. The Architecture of Markets. Princeton, NJ: Princeton University Press.

Fligstein, Neil and Peter Brantley. 1992. "Bank Control, Owner Control, or Organizational Dynamics: Who Controls the Large Modern Corporation?" American Journal of Sociology 98:280-307.

Fligstein, Neil and Linda Markowitz. 1993. "Financial Reorganization of American Corporations in the 1980s." Pp. 185-206 in Sociology and the Public Agenda, edited by W. J. Wilson. Beverly Hills, CA: Sage Publications.

Fligstein, Neil and Taek-Jin Shin. 2004. "The Shareholder Value Society: A Review of the Changes in Working Conditions and Inequality in the U.S. 1976-2000." Pp. 401-432 in Social Inequality, edited by K. M. Neckerman. New York: Russell Sage Foundation. Fligstein, Neil and Taekjin Shin. 2007. "Shareholder Value and the Transformation of the American Economy, 1984-2001." Sociological Forum 22:399-424.

Flynn, Laurie J. 2006. "Sun Says It Will Cut at Least 4,000 Jobs." Pp. 1 in New York Times. Freeman, Richard B. and James L. Medoff. 1984. What Do Unions Do? New York: Basic Books. Friedland, Roger and Robert R. Alford. 1991. "Bringing Society Back In: Symbols, Practices, and Institutional Contradictions." in The New Institutionalism in Organizational Analysis, edited by W. W. Powell and P. J. DiMaggio. 
Gaither, Chris. 2001. "Dell Computer to Cut Work Force by 4\%." Pp. 3 in New York Times. New York.

Gillan, Stuart L. and Laura T. Starks. 2000. "Corporate Governance Proposals and Shareholder Activism: The Role of Institutional Investors." Journal of Financial Economics 57:275305.

Glader, Paul. 2006. "Alcoa to Shed Soft-Alloys Business, Cut Jobs by 10\% in Restructuring." Pp. 2 in Wall Street Journal. New York.

Goldfield, Michael. 1987. The Decline of Organized Labor in the United States. Chicago: University of Chicago Press.

Goldstein, Adam. 2012. "Revenge of the Managers: Labor Cost-Cutting and the Paradoxical Resurgence of Managerialism in the Shareholder Value Era, 1984 to 2001 " American Sociological Review 77:268-294.

Gordon, David M. 1996. Fat and Mean: The Corporate Squeeze of Working Americans and the Myth of Managerial "Downsizing". New York: Free Press.

Gordon, Jeffrey N. 2007. "The Rise of Independent Directors in the United States, 1950-2005: Of Shareholder Value and Stock Market Prices." Stanford Law Review 59:1465-1568.

Gourevitch, Peter A. and James Shinn. 2005. Political Power and Corporate Control: The New Global Politics of Corporate Governance. Princeton: Princeton University Press.

Granovetter, Mark. 1985. "Economic Action and Social Structure: The Problem of Embeddedness." American Journal of Sociology 91:481-510.

Greene, William H. 2008. Econometric Analysis. Upper Saddle River, NJ: Pearson Prentice Hall. 
Greenwood, Royston, Amalia Magan Diaz, Stan Xiao Li, and Jose Cespedes Lorente. 2010. "The Multiplicity of Institutional Logics and the Heterogeneity of Organizational Responses." Organization Science 21:521-539.

Greenwood, Royston and Roy Suddaby. 2006. "Institutional Entrepreneurship in Mature Fields: The Big Five Accounting Firms." Academy of Management Journal 49:27-48.

Greve, Henrich R. 1995. "Jumping Ship: The Diffusion of Strategy Abandonment." Administrative Science Quarterly 40:444-473.

Grimsley, Kirstin Downey. 1995. "The Ax That Cuts Both Ways; Downsizing's Human Costs Outweigh Economic Gains, Many Experts Now Say." Pp. H01 in Washington Post.

Guthrie, James P. and Deepak K. Datta. 2008. "Dumb and Dumber: The Impact of Downsizing on Firm Performance as Moderated by Industry Conditions." Organization Science 19:108-123.

Hafner-Burton, Emilie M and Kiyoteru Tsutsui. 2005. "Human Rights in a Globalizing World: The Paradox of Empty Promises." American Journal of Sociology 110:1373-1411.

Hall, Peter A. and David Soskice. 2001. Varieties of Capitalism: The Institutional Foundations of Comparative Advantage. New York: Oxford University Press.

Halliday, Terence C. and Bruce G. Carruthers. 2007. "The Recursivity of Law: Global Norm Making and National Lawmaking in the Globalization of Corporate Insolvency Regimes." American Journal of Sociology 112:1135-1202.

—. 2009. Bankrupt: Global Lawmaking and Systemic Financial Crisis. Stanford, CA: Stanford University Press.

Hallock, Kevin F. 1998. "Layoffs, Top Executive Pay, and Firm Performance." American Economic Review 88:711-723. 
Hambrick, Donald C. and Sydney Finkelstein. 1995. "The Effects of Ownership Structure on Conditions at the Top: The Case of CEO Pay Raises." Strategic Management Journal 16:175-193.

Hammer, Michael and James Champy. 1993. Reengineering the Corporation: A Manifesto for Business Revolution. New York: HarperBusiness.

Hannan, Michael T. and John H. Freeman. 1989. Organizational Ecology. Cambridge: Harvard University Press.

Hannan, Michael T. and Glenn R. Carroll. 1992. Dynamics of Organizational Populations: Density, Legitimation, and Competition. New York: Oxford University Press.

Hannan, Michael T., Glenn R. Carroll, Elizabeth A. Dundon, and John Charles Torres. 1995. "Organizational Evolution in a Multinational Context: Entries of Automobile Manufacturers in Belgium, Britain, France, Germany, and Italy." American Sociological Review 60:509-528.

Harrison, Bennett and Barry Bluestone. 1988. The Great U-Turn: Corporate Restructuring and the Polarizing of America. New York: Basic Books.

Hartzell, Jay C. and Laura T. Starks. 2003. "Institutional Investors and Executive Compensation." Journal of Finance 58:2351-2374.

Haveman, Heather A. 1993. "Follow the Leader: Mimetic Isomorphism and Entry into New Markets." Administrative Science Quarterly 38:593-627.

Haveman, Heather A. and Hayagreeva Rao. 1997. "Structuring a Theory of Moral Sentiments: Institutional and Organizational Coevolution in the Early Thrift Industry." American Journal of Sociology 102:1606-1651. 
Henisz, Witold J. and Bennet A. Zelner. 2005. "Legitimacy, Interest Group Pressures, and Change in Emergent Institutions: The Case of Foreign Investors and Host Country Governments." Academy of Management Review 30:361-382.

Henisz, Witold J., Bennet A. Zelner, and Mauro F. Guillen. 2005. "The Worldwide Diffusion of Market-Oriented Infrastructure Reform, 1977-1999." American Sociological Review 70:871-897.

Hirsch, Barry T. and David A. Macpherson. 2003. "Union Membership and Coverage Database from the Current Population Survey: Note." Industrial and Labor Relations Review $56: 349-54$

Hirsch, Paul M. and Michaela De Soucey. 2006. "Organizational Restructuring and Its Consequences: Rhetorical and Structural." Annual Review of Sociology 32:171-189.

Hoffman, Andrew J. 1999. "Institutional Evolution and Change: Environmentalism and the U.S. Chemical Industry." Academy of Management Journal 42:351-371.

Holusha, John. 1987. "Ford and U.A.W. Agree on New Pact." Pp. P1 in New York Times. New York.

—. 1993. "A Profitable Xerox Plans to Cut Staff by 10,000." in New York Times. New York. Huddleston, Susan. 1986. "IBM To Close Greencastle Center, Displacing Nearly 1,000 Workers." in The Associated Press. Indianapolis.

Huson, Mark R., Robert Parrino, and Laura T. Starks. 2001. "Internal Monitoring Mechanisms and CEO Turnover: A Long-Term Perspective." Journal of Finance 56:2265-2297. Ingram, Paul and Hayagreeva Rao. 2004. "Store Wars: The Enactment and Repeal of AntiChain-Store Legislation in America." American Journal of Sociology 110:446-487. 
Ingram, Paul and Tal Simons. 2000. "State Formation, Ideological Competition, and the Ecology of Israeli Workers' Cooperatives, 1920-1992." Administrative Science Quarterly 45:25-53. Jacoby, Sanford M. 1985. Employing Bureaucracy: Managers, Unions, and the Transformation of Work in American Industry, 1900-1945. New York: Columbia University Press.

—. 2007. "Principles and Agents: CalPERS and Corporate Governance in Japan." Corporate Governance 15:5-15.

—. 2008. "Finance and Labor: Perspectives on Risk, Inequality, and Democracy." Comparative Labor Law and Policy Journal 30:45-65.

Jensen, Michael C. 1984. "Takeovers: Folklore and Science." Harvard Business Review 62:109121.

—. 1986. "Agency Costs of Free Cash Flow, Corporate Finance, and Takeovers." American Economic Review 76:323-329.

—. 1989. "Eclipse of the Public Corporation." Harvard Business Review 67:61-74.

—. 1993. "The Modern Industrial Revolution, Exit, and the Failure of Internal Control Systems." Journal of Finance 48:831-880.

Jensen, Michael C. and William H. Meckling. 1976. "Theory of the Firm: Managerial Behavior, Agency Costs, and Ownership Structure." Journal of Financial Economics 3:305-360.

Jensen, Michael C., Kevin J. Murphy, and Eric Wruck. 2004. "Remuneration: Where We've Been, How We Got to Here, What Are the Problems, and How to Fix Them." Boston, MA: Harvard Business School.

Jepperson, Ronald L. 1991. "Institutions, Institutional Effects, and Institutionalism." Pp. 143-163 in The New Institutionalism in Organizational Analysis, edited by W. W. Powell and P. J. DiMaggio. Chicago: University of Chicago Press. 
Kalleberg, Arne L. 2009. "Precarious Work, Insecure Workers: Employment Relations in Transition." American Sociological Review 74:1-22.

Kang, Jun-Koo and Anil Shivdasani. 1997. "Corporate Restructuring during Performance Declines in Japan." Journal of Financial Economics 46:29-65.

Katz, Harry C. 1985. Shifting Gears: Changing Labor Relations in the U.S. Automobile Industry. Cambridge, MA: MIT Press.

Kaufman, Bruce E. 1982. "The Determinants of Strikes in the United States, 1900-1977." Industrial and Labor Relations Review 35:473-490.

Khurana, Rakesh. 2002. Searching for a Corporate Savior: The Irrational Quest for Charismatic CEOs. Princeton, NJ: Princeton University Press.

—. 2007. From Higher Aims to Hired Hands: The Social Transformation of American Business Schools and the Unfulfilled Promise of Management as a Profession. Princeton, NJ: Princeton University Press.

Kim, Tai-Young, Dongyoub Shin, Hongseok Oh, and Young-Chul Jeong. 2007. "Inside the Iron Cage: Organizational Political Dynamics and Institutional Changes in Presidential Selection Systems in Korean Universities, 1985-2002." Administrative Science Quarterly 52:286-323.

King, Brayden G. and Nicholas A. Pearce. 2010. "The Contentiousness of Markets: Politics, Social Movements, and Institutional Change in Markets." Annual Review of Sociology $36: 249-267$.

King, Gary, James Honaker, Anne Joseph, and Kenneth Scheve. 2001. "Analyzing Incomplete Political Science Data: An Alternative Algorithm for Multiple Imputation." American Political Science Review 95:49-69. 
Kochan, Thomas A. forthcoming. "What It Will Take to Make Human Capital a Real Source of Competitive Advantage and Rising Living Standards in the American Economy." Harvard Business Review.

Kochan, Thomas A., Harry C. Katz, and Robert B. McKersie. 1994. The Transformation of American Industrial Relations. Ithaca, NY: ILR Press.

Kostova, Tatiana and Kendall Roth. 2002. "Adoption of an Organizational Practice by Subsidiaries of Multinational Corporations: Institutional and Relational Effects." Academy of Management Journal 45:215-233.

Krebs, Michelle. 1998. "G.M. Will Pare as Many as 1,000 White-Collar Jobs." in New York Times. New York.

Lang, Larry H. P. and Rene M. Stulz. 1994. "Tobin's q, Corporate Diversification, and Firm Performance." Journal of Political Economy 102:1248-1280.

Langreth, Robert. 1997. "Kimberly-Clark's Sweeping Cutbacks Should Ease Overcapacity, Analysts Say." Pp. 3 in Wall Street Journal. New York.

Lazonick, William and Mary O'Sullivan. 2000. "Maximizing Shareholder Value: A New Ideology for Corporate Governance." Economy and Society 29:13-35.

Lee, Peggy M. 1997. "A Comparative Analysis of Layoff Announcements and Stock Price Reactions in the United States and Japan." Strategic Management Journal 18:879-894.

Leicht, Kevin T. 1989. "On the Estimation of Union Threat Effects." American Sociological Review 54:1035-1047.

Love, E. Geoffrey and Matthew Kraatz. 2009. "Character, Conformity, or the Bottom Line? How and Why Downsizing Affecting Corporate Reputation." Academy of Management Journal 52:314-335. 
Love, E. Geoffrey and Nitin Nohria. 2005. "Reducing Slack: The Performance Consequences of Downsizing by Large Industrial Firms, 1977-93." Strategic Management Journal 26:1087-1108.

Mackenzie, Donald and Yuval Millo. 2003. "Constructing a Market, Performing Theory: The Histotrical Sociology of a Financial Derivatives Exchange." American Journal of Sociology 109:107-45.

Marquis, Christopher and Z. H. I. Huang. 2009. "The Contingent Nature of Public Policy and the Growth of U.S. Commercial Banking." Academy of Management Journal 52:1222-1246. Marquis, Christopher and Michael Lounsbury. 2007. "Vive La Resistance: Competing Logics and the Consolidation of U.S. Community Banking." Academy of Management Journal 50:799-820.

Martin, Andrew W and Marc Dixon. 2010. "Changing to Win? Threat, Resistance, and the Role of Unions in Strikes, 1984-2002." American Journal of Sociology 116:93-129.

McAdam, Doug. 1982. Political Process and the Development of Black Insurgency, 1930-1970. Chicago: University of Chicago Press.

McCammon, Holly J. 1993. "From Repressive Intervention to Integrative Prevention: The U.S. State's Legal Management of Labor Militancy, 1881-1978." Social Forces 71:569-601.

Medoff, James L. 1979. "Layoffs and Alternatives under Trade Unions in U.S. Manufacturing." American Economic Review 69:380-395.

Meyer, David G. and William N. Cooke. 1993. "US Labor Relations in Transition: Emerging Strategies and Company Performance." British Journal of Industrial Relations 31:531552. 
Meyer, David S. and Suzanne Staggenborg. 1996. "Movements, Countermovements, and the Structure of Political Opportunity." American Journal of Sociology 101:1628-1660.

Meyer, John W. and Brian Rowan. 1977. "Institutionalized Organizations: Formal Structure as Myth and Ceremony." American Journal of Sociology 83:340-363.

Mezias, Stephen J. 1990. "An Institutional Model of Organizational Practice: Financial Reporting at the Fortune 200." Administrative Science Quarterly 35:431-457.

Mintz, Beth and Michael Schwartz. 1985. The Power Structure of American Business. Chicago: University of Chicago Press.

Mizruchi, Mark S. and Lisa C. Fein. 1999. "The Social Construction of Organizational Knowledge: A Study of the Uses of Coercive, Mimetic, and Normative Isomorphism." Administrative Science Quarterly 44:653-683.

Mizruchi, Mark S., Linda Brewster Stearns, and Christopher Marquis. 2006. "The Conditional Nature of Embeddedness: A Study of Borrowing by Large U.S. Firms, 1973-1994." American Sociological Review 71:310-333.

Montgomery, Mark. 1991. "New Evidence on Unions and Layoff Rates." Industrial and Labor Relations Review 44:708-721.

Murray, Matt. 1995. "Thanks, Goodbye: Amid Record Profits, Companies Continue to Lay off Employees." Pp. A1 in Wall Street Journal. New York.

Nixon, Robert D., Michael A. Hitt, Ho-Uk Lee, and Eui Jeong. 2004. "Market Reactions to Announcements of Corporate Downsizing Actions and Implementation Strategies." Strategic Management Journal 25:1121-1129. 
Ocasio, William and Hyosun Kim. 1999. "The Circulation of Corporate Control: Selection of Functional Backgrounds of New CEOs in Large U.S. Manufacturing Firms, 1981-1992." Administrative Science Quarterly 44:532-562.

Oliver, Christine. 1991. "Strategic Responses to Institutional Processes." Academy of Management Review 16:145-179.

Osterman, Paul. 1999. Securing Prosperity: The American Labor Market: How It Has Changed and What to Do about It. Princeton, NJ: Princeton University Press.

Pache, Anne-Claire and Filipe Santos. 2010. "When Worlds Collide: The Internal Dynamics of Organizational Responses to Conflicting Institutional Demands." Academy of Management Review 35:455-476.

Palepu, Krishna. 1985. "Diversification Strategy, Profit Performance and the Entropy Measure." Strategic Management Journal 6:239-255.

Palmon, Oded, Huey-Lian Sun, and Alex P. Tang. 1997. "Layoff Announcements: Stock Market Impact and Financial Performance." Financial Management 26:54-68.

Parrino, Robert, Richard W. Sias, and Laura T. Starks. 2003. "Voting with Their Feet: Institutional Ownership Changes around Forced CEO Turnover." Journal of Financial Economics 68:3-46.

Perrow, Charles. 1986. Complex Organizations: A Critical Essay. New York: Random House. Perry, Tod and Anil Shivdasani. 2005. "Do Boards Affect Performance? Evidence from Corporate Restructuring." Journal of Business 78:1403-1431.

Pfeffer, Jeffrey and Gerald R. Salancik. 1978. The External Control of Organizations: A Resource Dependence Perspective. New York: Harper \& Row. 
Powell, Walter W. 1991. "Expanding the Scope of Institutional Analysis." Pp. 183-203 in The New Institutionalism in Organizational Analysis, edited by W. W. Powell and P. J. DiMaggio. Chicago, IL: University of Chicago Press.

Prechel, Harland. 2000. Big Business and the State: Historical Transitions and Corporate Transformation, 1880s-1990s. Albany: State University of New York Press.

Prechel, Harland and Theresa Morris. 2010. "The Effects of Organizational and Political Embeddedness on Financial Malfeasance in the Largest U.S. Corporations." American Sociological Review 75:331-354.

Prinstin, Terry. 1998. "Bell Atlantic Tries to Halt Exodus of Workers Retiring Early." Pp. 27 in New York Times. New York.

Rao, Hayagreeva, Philippe Monin, and Rodolphe Durand. 2003. "Institutional Change In Toque Ville: Nouvelle Cuisine as an Idensity Movement in French Gastronomy." American Journal of Sociology 108:795-843.

Rao, Hayagreeva and Kumar Sivakumar. 1999. "Institutional Sources of Boundary-Spanning Structures: The Establishment of Investor Relations Departments in the Forture 500 Industrials." Organization Science 10:27-42.

Roe, Mark J. 1994. Strong Managers, Weak Owners: The Political Roots of American Corporate Finance. Princeton, NJ: Princeton University Press.

—. 2003. Political Determinants of Corporate Governance: Political Context, Corporate Impact. New York: Oxford University Press.

Rosenfeld, Jake. 2006. "Desperate Measures: Strikes and Wages in Post-Accord America." Social Forces 85:235-265. 
Roy, William G. 1997. Socializing Capital: The Rise of the Large Industrial Corporation in America. Princeton, NJ: Princeton University Press.

Ruef, Martin. 2000. "The Emergence of Organizational Forms: A Community Ecology Approach." American Journal of Sociology 106:658-714.

—. 2004. "The Demise of an Organizational Form: Emancipation and Plantation Agriculture in the American South, 1860-1880." American Journal of Sociology 109:1365-1410.

Ruef, Martin and W. Richard Scott. 1998. "A Multidimensional Model of Organizational Legitimacy: Hospital Survival in Changing Institutional Environments." Administrative Science Quarterly 43:877-904.

Russo, Michael V. 2001. "Institutions, Exchange Relations, and the Emergence of New Fields: Regulatory Policies and Independent Power Production in America, 1978-1992." Administrative Science Quarterly 46:57-86.

Salancik, Gerald R. and Jeffrey Pfeffer. 1980. "Effects of Ownership and Performance on Executive Tenure in U.S. Corporations." Academy of Management Journal 23:653-664. Sanders, Gerard. 2001. "Behavioral Responses of CEOs to Stock Ownership and Stock Option Pay." Academy of Management Journal 44:477-492.

Sanders, Wm Gerard and Donald C. Hambrick. 2007. "Swinging for the Fences: The Effects of CEO Stock Options on Company Risk Taking and Performance." Academy of Management Journal 50:1055-1078.

Schneiberg, Marc and Tim Bartley. 2001. "Regulating American Industries: Markets, Politics, and the Institutional Determinants of Fire Insurance Regulation." American Journal of Sociology 107:101-146. 
Schneper, William D. and Mauro F. Guillen. 2004. "Stakeholder Rights and Corporate Governance: A Cross-National Study of Hostile Takeovers." Administrative Science Quarterly 49:263-295.

Scott, W. Richard. 1987. "The Adolescence of Institutional Theory." Administrative Science Quarterly 32:493-511.

—. 1995. Institutions and Organizations. Thousand Oaks, CA: Sage.

Seo, Myeong-Gu and W. E. Douglas Creed. 2002. "Institutional Contradictions, Praxis, and Institutional Change: A Dialectical Perspective." Academy of Management Review 27:222-247.

Serrin, William. 1986. "The Pain of the Steelworker." Pp. 1 in New York Times. New York.

Shleifer, Andrei and Robert W. Vishny. 1986. "Large Shareholders and Corporate Control." Journal of Political Economy 94:461-488.

Short, Jodi L. and Michael W. Toffel. 2010. "Making Self-Regulation More Than Merely Symbolic: The Critical Role of the Legal Environment." Administrative Science Quarterly 55:361-396.

Simons, Tal and Paul Ingram. 2003. "Enemies of the State: The Interdependence of Institutional Forms and the Ecology of the Kibbutz, 1910-1997." Administrative Science Quarterly 48:592-621.

Sine, Wesley D., Heather A. Haveman, and Pamela S. Tolbert. 2005. "Risky Business? Entrepreneurship in the New Independent-Power Sector." Administrative Science Quarterly 50:200-232.

Singer, Judith D. and John B. Willett. 2003. Applied Longitudinal Data Analysis: Modeling Change and Event Occurrence. New York: Oxford University Press. 
Snyder, David. 1975. "Institutional Setting and Industrial Conflict: Comparative Analyses of France, Italy and the United States." American Sociological Review 40:259-278.

Stearns, Linda Brewster and Kenneth D. Allan. 1996. "Economic Behavior in Institutional Environments: The Corporate Merger Wave of the 1980s." American Sociological Review 61:699-718.

Stevenson, Richard, W. 1985. "24,000 A.T.\&T. Jobs to Be Eliminated from Systems Unit." Pp. P1 in New York Times.

Strang, David and John W. Meyer. 1993. "Institutional Conditions for Diffusion." Theory and Society 22:487-511.

Stryker, Robin. 2000. "Legitimacy Processes as Institutional Politics: Implications for Theory and Research in the Sociology of Organizations." Pp. 179-223 in Research in the Sociology of Organizations, vol. 17, edited by S. Bacharach and E. J. Lawler. Greenwich, CT: JAI Press.

Suchman, Mark C. 1995. "Managing Legitimacy: Strategic and Institutional Approaches." Academy of Management Review 20:571-610.

Sutton, John R. and Frank Dobbin. 1996. "The Two Faces of Governance: Responses to Legal Uncertainty in U.S. Firms, 1955 to 1985." American Sociological Review 61:794-811.

Sutton, John R., Frank Dobbin, John W. Meyer, and W. Richard Scott. 1994. "The Legalization of the Workplace." American Journal of Sociology 99:944-971.

Swenson, Peter A. 2002. Capitalists against Markets: The Making of Labor Markets and Welfare States in the United States and Sweden. Oxford: Oxford University Press. 
Thornton, Patricia H. and William Ocasio. 1999. "Institutional Logics and the Historical Contingency of Power in Organizations: Executive Succession in the Higher Education Publishing Industry, 1958-1990." American Journal of Sociology 105:801-843.

Tolbert, Pamela S. and Lynne G. Zucker. 1983. "Institutional Sources of Change in the Formal Structure of Organizations: The Diffusion of Civil Service Reform, 1880-1935." Administrative Science Quarterly 28:22-39.

Tomaskovic-Devey, Donald and Ken-Hou Lin. 2011. "Income Dynamics, Economic Rents, and the Financialization of the U.S. Economy." American Sociological Review 76:538-559.

Tope, Daniel and David Jacobs. 2009. "The Politics of Union Decline: The Contingent Determinants of Union Recognition Elections and Victories." American Sociological Review 74:842-864.

Tosi, Henry L., Jr. and Luis R. Gomez-Mejia. 1989. "The Decoupling of CEO Pay and Performance: An Agency Theory Perspective." Administrative Science Quarterly 34:169189.

Uchitelle, Louis. 1996. "The New Buzz: Growth Is Good; Latest Strategy for Business Is a Positive Spin on Layoffs." in New York Times. New York.

—. 2006. The Disposable America. New York: Knopf.

Useem, Michael. 1993. Executive Defense: Shareholder Power and Corporate Reorganization. Cambridge, MA: Harvard University Press.

—. 1996. Investor Capitalism: How Money Managers Are Changing the Face of Corporate America. New York: Basic Books.

Vogus, Timothy J. and Gerald F. Davis. 2005. "Elite Mobilizations for Antitakeover Legislation, 1982-1990." Pp. 96-121 in Social Movements and Organization Theory, edited by G. F. 
Davis, D. McAdam, W. R. Scott, and M. N. Zald. New York: Cambridge University Press.

Voss, Kim and Rachel Sherman. 2000. "Breaking the Iron Law of Oligarchy: Union Revitalization in the American Labor Movement." American Journal of Sociology 106:303-349.

Wallace, Michael, Kevin T. Leicht, and Lawrence E. Raffalovich. 1999. "Unions, Strikes, and Labor's Share of Income: A Quarterly Analysis of the United States, 1949-1992." Social Science Research 28:265-288.

Wayhan, Victor B. and Steve Werner. 2000. "The Impact of Workforce Reductions on Financial Performance: A Longitudinal Perspective." Journal of Management 26:341-363.

Weber, Klaus, Gerald F. Davis, and Michael Lounsbury. 2009. "Policy as Myth and Ceremony? The Global Spread of Stock Exchanges, 1980-2005." Academy of Management Journal 52:1319-1347.

Weiler, Paul C. . 1990. Governing the Workplace: The Future of Labor and Employment Law. Cambridge: Harvard University Press.

Weisbach, Michael S. 1988. "Outside Directors and CEO Turnover." Journal of Financial Economics 20:431-460.

Westphal, James D., Ranjay Gulati, and Stephen M. Shortell. 1997. "Customization or Conformity? An Institutional and Network Perspective on the Content and Consequences of TQM Adoption." Administrative Science Quarterly 42:366-394.

Westphal, James D. and Edward J. Zajac. 1994. "Substance and Symbolism in CEOs' Long-term Incentive Plans." Administrative Science Quarterly 39:367-390. 
—. 1998. "The Symbolic Management of Stockholders: Corporate Governance Reforms and Shareholder Reactions." Administrative Science Quarterly 43:127-153.

—. 2001. "Decoupling Policy from Practice: The Case of Stock Repurchase Programs." Administrative Science Quarterly 46:202-228.

Worrell, Dan L., Wallace N. Davidson, III, and Varinder M. Sharma. 1991. "Layoff Announcement and Stockholder Wealth." Academy of Management Journal 34:662-678. Yermack, David 1995. "Do Corporations Award CEO Stock Options Effectively?" Journal of Financial Economics 39:237-269.

Zajac, Edward J. and James D. Westphal. 2004. "The Social Construction of Market Value: Institutionalization and Learning Perspectives on Stock Market Reactions." American Sociological Review 69:433-457.

Zbaracki, Mark J. 1998. "The Rhetoric and Reality of Total Quality Management." Administrative Science Quarterly 43:602-636.

Zelner, Bennet A., Witold J. Henisz, and Guy L. F. Holburn. 2009. "Contentious Implementation and Retrenchment in Neoliberal Policy Reform: The Global Electric Power Industry, 1989--2001." Administrative Science Quarterly 54:379-412.

Zhang, Xiaomeng, Kathryn M. Bartol, Ken G. Smith, Michael D. Pfarrer, and Dmitry M. Khanin. 2008. "CEOs on the Edge: Earnings Manipulation and Stock-Based Incentive Misalignment." Academy of Management Journal 51:241-258.

Zorn, Dirk M. 2004. "Here a Chief, There a Chief: The Rise of the CFO in the American Firm." American Sociological Review 69:345-364. 
Zorn, Dirk M., Frank Dobbin, Julian Dierkes, and Man-Shan Kwok. 2004. "Managing Investors: How Financial Markets Reshaped the American Firm." in The Sociology of Financial Markets, edited by K. Knorr Cetina and A. Preda. London: Oxford University Press.

Zuckerman, Ezra W. 1999. "The Categorical Imperative: Securities Analysts and the Illegitimacy Discount." American Journal of Sociology 104:1398-1438.

—. 2000. "Focusing the Corporate Product: Securities Analysts and De-diversification." Administrative Science Quarterly 45:591-619. 